\title{
INSTALACIONES FLUVIO-MARÍTIMAS DE DRENAJE CON ÁNFORAS ROMANAS: A PROPÓSITO DEL EMBARCADERO FLAVIO DEL CAÑO DE SANCTI PETRI (SAN FERNANDO, CÁDIZ)
}

\section{FLUVIAL AND MARITIME DRAINAGE INSTALLATIONS WITH ROMAN AMPHORAE: THE FLAVIAN WHARF AT CAÑO DE SANCTI PETRI (SAN FERNANDO, CÁDIZ)}

\author{
por \\ D. BERNAL*, A. M. SÁEZ*, \\ R. MONTERO, J. J. DÍAZ*,
} A. SÁEZ**, D. MORENO** y E. TOBOSO

RESUMEN

\begin{abstract}
En este trabajo se presentan los resultados del estudio e interpretación de una excavación de urgencia que tuvo lugar a principios de 1996 en la salina de San Cayetano en San Fernando (Cádiz), junto a una de las orillas del Caño de Sancti Petri. La estructura localizada se componía de una serie de alineaciones paralelas de ánforas romanas machihembradas, en posición horizontal, situadas en dos niveles y reforzadas entre sí por pilotes de madera de pino (datados por C-14), sobre las cuales se localizaron los restos de una pavimentación pétrea. El conjunto parece fecharse en época flavia a tenor de las precisiones derivadas del estudio de los envases ánforicos reutilizados, que ascienden a más de cuarenta (mayoritariamente salsarias béticas altoimperiales -Dr. 7/11, Beltrán II A y Beltrán II B-, olearias del Valle del Guadalquivir -Dr. 20- y otros tipos importados -Dr. 2/4 y Dr. 14-). Los paralelos edilicios localizados, especialmente en la zona noritálica (laguna de Venecia y llanura padana) y en la desembocadura del Ródano permiten relacionar esta estructura con los restos de una plataforma drenante hidrófuga destinada a garantizar la solidez y horizontalidad del substrato. Su localización en la orilla del Caño de Sancti Petri, unida al actual topónimo (Los Cargaderos) y a su relación con las villae altoimperiales situadas en las inmediaciones permiten interpretar este yacimiento como un posible embarcadero destinado a facilitar el tránsito de mercancías en esta zona del archipiélago gaditano. Al hilo de este hallazgo se plantean algunas reflexiones sobre las construcciones realizadas con ánforas en el ámbito de la isla de San Fernando (como reflejo de la problemática general de la Bahía de Cádiz) y especialmente sobre el uso de madera en las instalaciones portuarias hispanorromanas.
\end{abstract}

\footnotetext{
* Universidad de Cádiz

** Museo Histórico Municipal de San Fernando
} 


\begin{abstract}
We present in this paper the results of the archaeological study of a rescue excavation carried out in 1996 in the so called "Salina de San Cayetano" in the city of San Fernando (Cádiz), near one of the banks of the "Caño de Sancti Petri". The structure is composed of two levels of interconnected amphorae located in parallel horizontal lines, reinforced by pine stakes, underneath a small stones pavement. The site is dated in flavian times according to the information provided by the more than forty reused vessels (mainly baetican amphorae for fish -Dr. 7/11, Beltrán II A and Beltrán IIB-, oil amphorae from the Guadalquivir valley -Dr. 20- and other imported ones -Dr. 2/4 and Dr. 14-). The parallels found, specially in northern Italy (area of Venice and the Po plain) and in the Rhone river let us relate this structure to a draining platform. Its location by the river side, the name of the site ("Los Cargaderos" $=$ dockers) and the vicinity of some early roman villae show that we are in front of a small roman wharf in the Bay of Cádiz. Some observations concerning the reusing of amphorae for architectural purposes and the use of wood in the hispanorroman harbour installations are also discussed.
\end{abstract}

Palabras claves embarcadero romano, ánforas, madera de pino, época flavia

Key words roman wharf, amphorae, pine wood, flavian times

\title{
1. INTRODUCCIÓN ${ }^{1}$
}

La importancia de Gades y su hinterland en el tráfico comercial de la Hispania romana es una cuestión sobradamente conocida en los estudios sobre la Historia Económica de las provincias occidentales. Baste recordar cómo recientemente se ha llegado incluso a plantear una "gaditanización de Hispania", proyectando ese carácter de foco civilizador que siempre tuvo la Bahía de Cádiz a otros puntos de la Península Ibérica, Tingitana y las costas atlánticas (Chic 2004).

Y si una característica ha ido siempre unida indisolublemente a la economía marítima de Gades ésta ha sido su carácter bipolar. Por un lado, uno de los puertos más importantes del Mediterráneo Occidental, a tenor de ese comercio de redistribución que tanto caracterizó a las sociedades de la Antigüedad Clásica, cuya fama está bien atestiguada por las fuentes literarias y así ha sido reflejada en los trabajos de síntesis sobre la cuestión (Lehmann-Hartleben 1923; Spaar 1981; Blackman 1990; recientemente García et alii 2004). Por otro, una economía productiva basada fundamentalmente en la explotación de los recursos del mar y especialmente en la elaboración de conservas de pescado en sus dos variedades básicas, el pescado salado -salsamenta- y las pastas/salsas de origen piscícola -garum, muria, liquamen, allec...-. En este contexto se sitúa el trabajo que presentamos en estas páginas, destinado al estudio del yacimiento de Los Cargaderos en San Fernando, cuya vinculación con actividades de carácter portuario y mercantil es la propuesta que traemos a colación. La notable importancia del puerto de Gades, revalorizada al hilo de los trabajos geoarqueológicos recientemente realizados por el equipo de la Universidad de Sevilla y la Universidad de Bremen (Arteaga et alii 2001) debe ser a nuestro juicio puesta en conexión con la pionera y aguda -pero infravalorada y casi olvidada- propuesta de C. Pemán que valoraba la existencia de una tupida red de embarcaderos asociados a la red de canales interiores de la Bahía de Cádiz (1959), necesarios para dar salida a las ánforas de los alfares situados en tierra firme, aislados de las aguas de la bahía por los cordones marismeños consolidados, tal y como los estudios geoarqueológicos más recientes se han encargado de confirmar.

1. Este trabajo se inscribe en el marco de desarrollo del Grupo de Investigación HUM-671 del III P.A.I. de la Junta de Andalucía. 
Se presenta a continuación la problemática de este yacimiento, inédito hasta la actualidad a excepción de algunas breves referencias, aparecido con motivo de una actuación de urgencia acometida por el equipo técnico del Museo Histórico Municipal de San Fernando (=MHMSF) en el año 1996. En primer lugar, analizaremos su localización geográfica y problemática paleogeográfica, continuando con la presentación de la actuación arqueológica realizada y los datos obtenidos durante el trabajo de campo. En tercer lugar se procede a evaluar los paralelos documentados de este tipo de estructuras, que se sitúan especialmente en dos ámbitos geográficos de similares características geomorfológicas: la llanura del Po y la laguna veneta en el Norte de Italia, y las estructuras localizadas en el sur de Francia, en las inmediaciones de la desembocadura del Ródano. Se ha considerado de utilidad, debido al carácter inédito de esta temática, presentar un listado con todas las instalaciones constructivas conocidas en la actualidad en el ámbito de la isla de San Fernando y otros ejemplos de la Bahía de Cádiz que han utilizado ánforas como partes integrantes de su estructura, habiendo censado más de una decena de localizaciones, la mayor parte de ellas canalizaciones. Al final se presenta el estudio detallado del contexto anfórico documentado, del cual se han seleccionado 34 individuos que permitirán, adicionalmente, obtener datos indirectos de referencia sobre la dinámica comercial de esta zona del Caño de Sancti Petri en época altoimperial. Y por último, se propone una propuesta de interpretación histórico-arqueológica de los hallazgos de Los Cargaderos, en la línea de una posible plataforma de carga relacionada con los embarcaderos romanos que daban salida a las numerosas instalaciones productivas agropecuarias situadas en la banda costera oriental de la isla de San Fernando, al tiempo que la estructura constituiría un sistema de refuerzo de la orilla del caño, como se infiere del estudio de los paralelos con los ejemplos itálicos y gálicos documentados.

\section{GEOGRAFÍA Y GEOMORFOLOGÍA DE LOS CARGADEROS. ENTRE MARISMAS CONSOLIDADAS Y PALEOCANALES}

El yacimiento de Los Cargaderos está situado en el barrio de Gallineras, en la zona meridional del término municipal de San Fernando (Cádiz). Esta localidad constituye una de las antiguas islas del archipiélago gaditano, hoy unida a tierra firme a lo largo de toda su superficie, generando una zona de desarrollo territorial en torno a una franja central cuya máxima elevación se sitúa en el Cerro de los Mártires, muy próximo a lo que debió ser la costa en época protohistórica y antigua (figura $1 \mathrm{~A}$ y B), alejada ahora un tanto debido a los aterramientos que han dado lugar a la formación de marismas que sólo son inundadas por mareas vivas (Fernández-Palacios, Fernández-Palacios y Gil 1988).

La primera cuestión que queremos poner sobre la mesa es el carácter de insularidad de la zona, tanto actualmente como en la Antigüedad, ya que sus límites son casi exclusivamente acuáticos (Caño de Sancti Petri al este, Océano Atlántico al sur y Bahía de Cádiz al norte y oeste).

La segunda cuestión es incidir en la importancia de los cordones marismeños consolidados que rodeaban la isla de San Fernando desde época protohistórica con seguridad. La consecuencia más palpable de los activos procesos geomorfológicos y de dinámica litoral es el intenso proceso de colmatación que ha sufrido toda la zona debido a los aportes sedimentarios que arrastraron el Río Guadalete y otros cursos fluviales secundarios tales como el Río Arillo o el Caño Sancti Petri, que limitan con San Fernando al norte y al sur respectivamente. Remitimos a los estudios más recientes al respecto para valorar en detalle estas cuestiones geomorfológicas, especialmente las relacionadas con el proceso de colmatación de determinadas zonas de la bahía interior (Alonso, Gracia y Benavente 2004; Arteaga et alii 2001). Todas estas cuestiones, recientemente relanzadas de la mano de estudios geoarqueológicos por parte de diversos investigadores, convergen en situar a la zona oriental de la isla de San Fernando como un ambiente costero caracterizado por la presencia de marismas, y en el cual la navegabilidad, posiblemente a través de paleocanales, debió constituir una realidad cotidiana.

ISSN: 1133-4525 ISSN-e: 2255-3924

SPAL 14 (2005)

http://dx.doi.org/10.12795/spal.2005.i14.07 
El interés que reviste la localización geográfica del yacimiento de Los Cargaderos es diversa (figura 1, $\mathrm{n}^{\mathrm{o}} 1$ ), y permite avanzar en una serie de aspectos preliminares, como veremos a continuación:

1) Confirmación de la consolidación de la marisma. Por un lado ha permitido constatar la existencia de yacimientos alejados del reborde costero de la isla unos 300/350 mts, como se advierte en las figura 1 B y 2 A. Actualmente, la reconstrucción indirecta de la línea de paleo-costa en época romana deriva de la localización geográfica de los yacimientos en esta zona, que definen un trazado prácticamente lineal. Así permiten confirmarlo las recientes propuestas de localización de yacimientos con motivo de la elaboración de la Carta Arqueológica de San Fernando, pues se define un eje norte-sur entre la necrópolis de la Salina San Cayetano, la villa de Avda. de Constitución-Huerta del Contrabandista (figura $1, \mathrm{n}^{\circ} 15$ ), la villa/complejo termal del Cerro de la Batería (figura $1, \mathrm{n}^{\circ} 10$ ), las estructuras industriales de Residencial La Ermita (figura 1, $\mathrm{n}^{\circ}$ 9) y La Marquina, y la villa marítima de Gallineras (figura $1, \mathrm{n}^{\mathrm{o}} 6$ ), como se puede apreciar en la figura $1 \mathrm{~B}$. Evidentemente nos encontramos por el momento ante el primer y único testimonio de una realidad que debió ser mucho más compleja en época antigua. Se podría plantear una conexión directa entre este yacimiento y las villas romanas del reborde terrestre de la isla, hecho que invalidaría su potencial como evidencia directa del proceso de consolidación de la marisma en época romana. Pensamos que las características geológicas de la matriz de los niveles en los cuales se encontraron insertas las ánforas de esta estructura, compuesta por el característico fango gris-verdoso propio de las marismas, constituye un testimonio clarividente contrario a tal propuesta.

2) Documentación del nivel de paleosuelo de época romana en esta zona. Como veremos a continuación, la existencia de una pavimentación sobre la parte superior de la estructura de drenaje permite contar con un dato empírico sobre la altura del nivel al cual se encontraban las marismas en esta zona del término municipal en época romana, algo inferior al actual, al menos en momentos muy avanzados del s. I d.C. No olvidemos que la excavación de las estructuras tuvo que ser realizada con una motobomba que permitiese el achique de agua, al situarse toda la estructura sensiblemente por debajo del nivel de agua en pleamar (figura 2B). Esta cuestión pensamos es de gran interés para valorar recientes trabajos de investigación relacionados con la mutación del nivel del mar en esta época (cfr. al respecto Alonso et alii 2003 a y 2004).

3) Confirmación indirecta de la navegabilidad del Caño de Sancti Petri. Cuestión ésta obvia, atendiendo a la documentación existente de época medieval y moderna sobre la intensa actividad marítima para conectar las aguas interiores de la Bahía de Cádiz con el océano, encuentra, por primera vez para época romana, el testimonio de un punto de escala a lo largo de una de sus orillas, en una zona bastante al interior de su tramo meridional. No obstante, en esta misma línea se sitúan evidencias como los hallazgos subacuáticos frecuentes del área Estanquillo-Almadraba, o el pecio de la entrada sur del caño (Bernal et alii 2004).

4) Por último, y desde un punto de vista geoarqueológico, hay un último aspecto sobre el que consideramos necesario incidir para un mejor conocimiento de la dinámica litoral de toda esta zona oriental de la isla de San Fernando en época romana. Nos referimos a la existencia de paleocanales de comunicación entre estas zonas de marismas, brazos de mar que luego se habrían rellenado hasta formar las marismas, como han planteado acertadamente multitud de autores (Pemán 1959; Chic 1979). Recurriendo a la cartografía histórica, única fuente fidedigna por el momento ante la ausencia de estudios geoarqueológicos en detalle sobre esta cuestión en el lugar, como ya han planteado otros autores recientemente (Alonso, Gracia y Benavente 2004: 272-274), nos encontramos con una tupida red de paleocanales hoy inexistentes. 


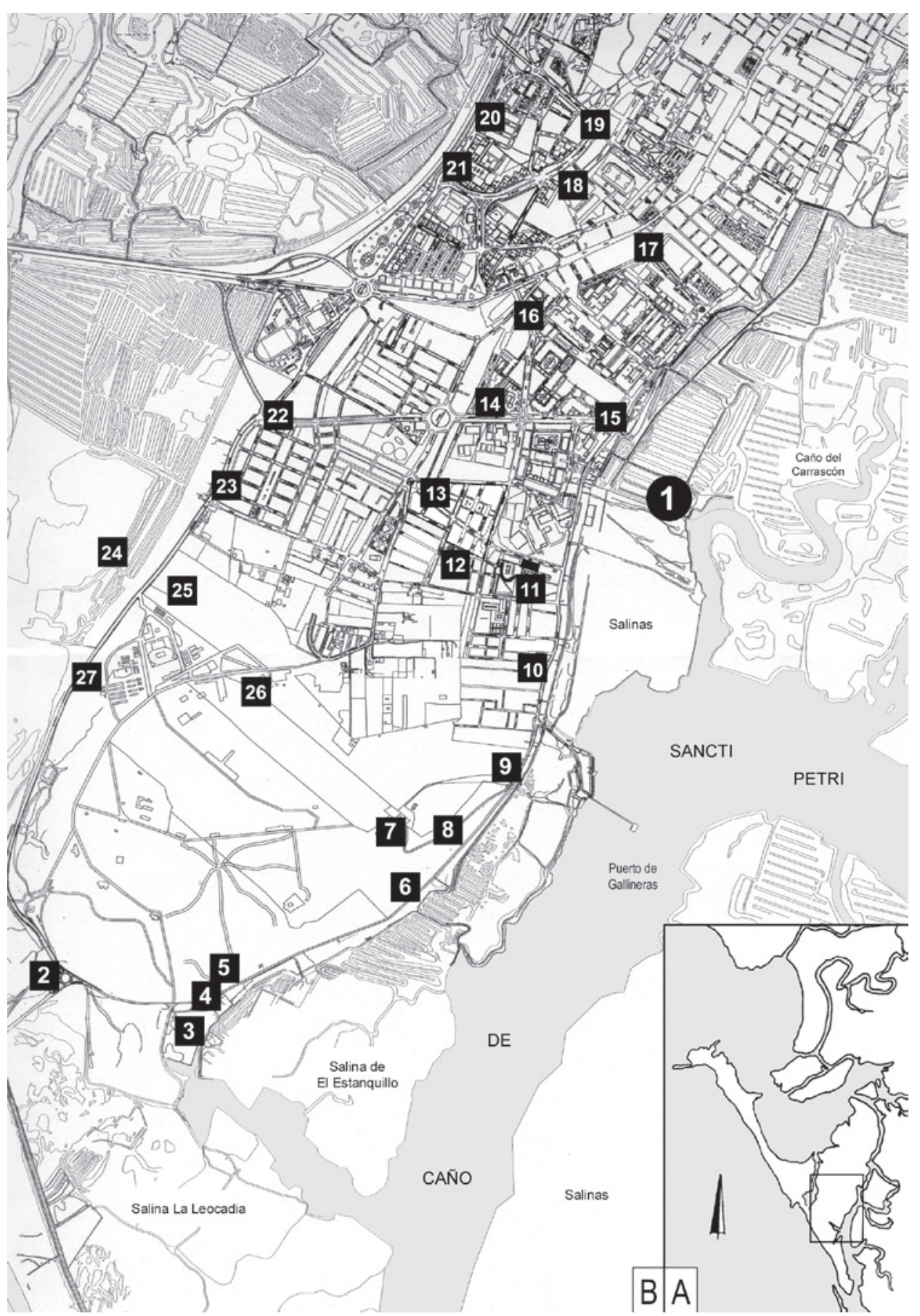

Figura 1. Localización del yacimiento de Los Cargaderos (1). A. Situación en el archipiélago gaditano; B. Relación topográfica entre los diferentes yacimientos de la Isla de San Fernando, según la Carta Arqueológica de San Fernando (Bernal et alii 2004): Pozo Alcudia (2), Almadraba (3), Casa Pepe (4), El Estanquillo (5), Gallineras (6), Cerro de los Mártires (7), La Marquina (8), Residencial La Ermita (9), C/ Asteroides (10), Cerro de la Batería (11), Campo del Gayro (12), Sector III Camposoto (13), Centro Atlántida (14), Avda. Constitución (15), C/ Luis Milena (16), C/ Batallones de Marina (17), El Canal (18), Torre Alta (19), Pery Junquera II (20), Ardila (21), Parque Natural (22), La Milagrosa (23), Salina Tres Amigos (24), Huerta de la Compañía (25), Huerta de Sopranis (26), Eucaliptos (27). 

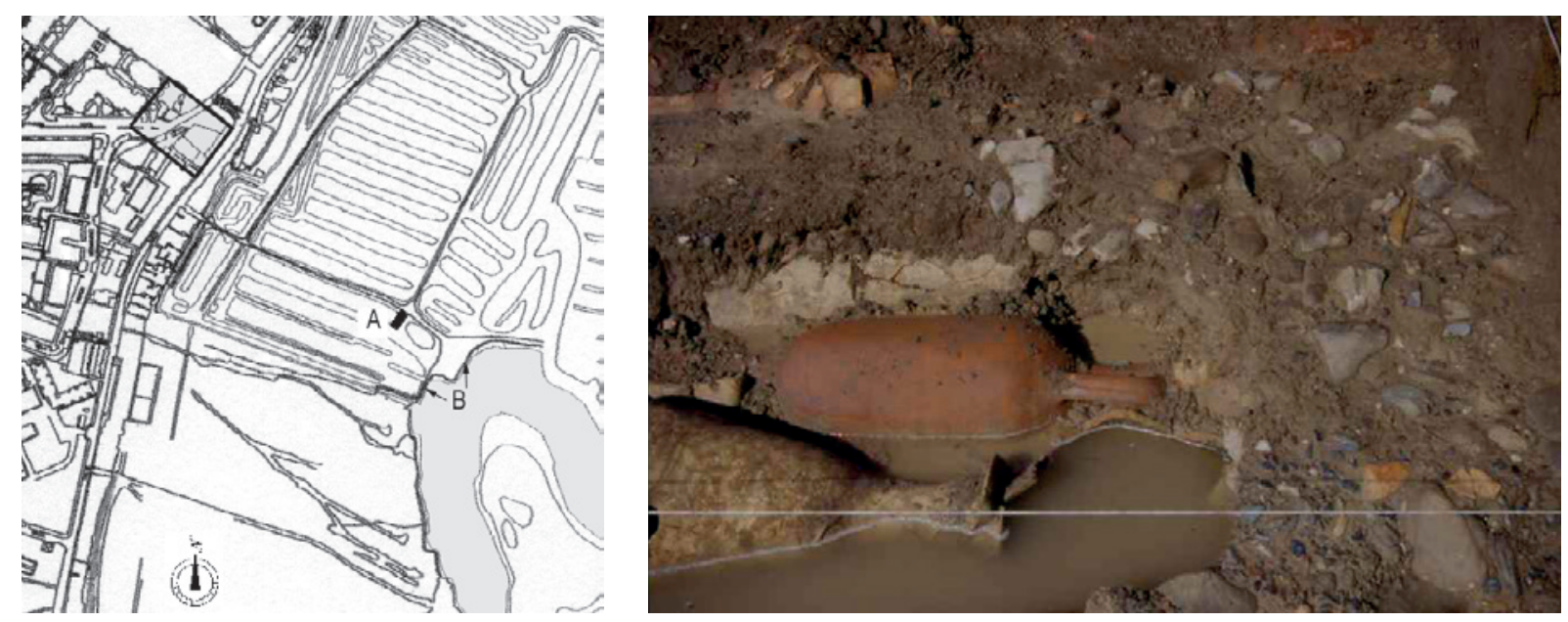

Figura 2.- Detalle de la planimetría de la zona excavada (izquierda), con indicación del Corte (A), de las cercanas estructuras del embarcadero aún en uso (B) y de la villa romana de Avda. Constitución (recuadro gris). Y detalle (derecha) de la pavimentación de guijarros en primer término -U.E. 2- (foto Archivo MHMSF).

Se ha considerado importante valorar concisamente la problemática geológica y geomorfológica del yacimiento de Los Cargaderos previamente a presentar el estudio detallado del mismo, pues en gran medida su interpretación deriva de los condicionantes paleogeográficos con los que se vincula. De ahí que su situación en un entorno de marismas consolidadas, a unos trescientos metros del reborde costero oriental de la isla y a escasos metros de la orilla actual del Caño de Sancti Petri sean elementos esenciales en su hermenéutica.

\section{LA ESTRUCTURA DE DRENAJE CON ÁNFORAS DE LOS CARGADEROS. CIRCUNSTANCIAS DEL HALLAZGO Y PROBLEMÁTICA}

\subsection{Planteamiento y desarrollo de la actuación arqueológica.}

Con motivo de las intensas lluvias registradas durante el día 13 de febrero de 1996, se produjo un hallazgo casual en la zona denominada de San Cayetano, al quedar inundadas parte de las salinas. Fruto del desplazamiento hídrico, quedaron al descubierto una serie de estructuras coincidiendo con uno de los tajos de salinas situados en la zona. La cantidad de hallazgos arqueológicos de ánforas romanas provocaron la alarma de los ciudadanos de las inmediaciones, que vehicularon inmediatamente el hallazgo a los responsables del Museo Histórico Municipal de San Fernando². Personados en el lugar los técnicos del MHMSF, comprobaron que se trataba de un depósito de ánforas de diversa tipología, todas ellas de época romana y formando algún tipo de estructura, por lo que desde un primer momento se planteó la importancia del yacimiento y la necesidad de realizar un control arqueológico en la zona. La actuación arqueológica en Los Cargaderos se desarrolló entre los días 14 a 17 de Febrero de 1996, bajo unas condiciones climatológicas de frío y lluvia adversas. Debido al alto riesgo de expolio en la zona en que se

2. El hallazgo del yacimiento se produjo por D. Carlos Quiñones Conde, alumno en dichas fechas del cercano centro escolar Eriteya, quien lo notificó al Director de dicho colegio, el cual avisó a las autoridades pertinentes. 
encontraban los restos, se contactó con el SEPRONA de la Guardia Civil, que mantuvieron la zona bajo vigilancia policial durante el desarrollo de los trabajos de campo para evitar expolios ${ }^{3}$.

La intervención arqueológica fue realizada con el apoyo y asesoramiento de la Fundación Municipal de Cultura del Ayuntamiento de San Fernando y con los medios técnicos y humanos del Museo Histórico Municipal de San Fernando. La dirección de la excavación estuvo a cargo del arqueólogo D. Moreno García, técnico del Museo isleño, siendo auxiliado durante su desarrollo por M. Macías López y A. Sáez Espligares, este último subdirector del Museo Histórico Municipal ${ }^{4}$. El objetivo principal planteado con esta intervención fue la documentación y posterior recuperación de los restos anfóricos romanos que se encontraban al aire libre, ante el carácter íntegro de algunos ejemplares y el consecuente riesgo de expolio. Debido al hallazgo en el interior de un tajo de salina actual, con terreno irregular compuesto de fangos y gran cantidad de agua, el proceso de excavación y recuperación fue complejo. Se intervino en una única área de excavación de $20 \mathrm{~m}^{2}$, excavando dos sondeos rectangulares de amplias dimensiones $(5 \times 2 \mathrm{~m})$, y procediendo a la excavación por estratos naturales. La localización de la trinchera mencionada se situó perpendicularmente al camino de acarreo por el que se accedía al yacimiento (figura 2 A), cuya orientación, similar a la ofrecida por los alineamientos de ánforas hallados, tenía como objetivo poder documentar la totalidad de restos anfóricos aparecidos. El sondeo situado más al norte se subdividió en cinco cuadrículas de 1 × $2 \mathrm{~m}$ con objeto de facilitar el estudio microespacial. El mismo proceso se realizó con la cata de análogas dimensiones localizada al sur, si bien el notable destrucción de los restos -ánforas muy fragmentadas, prácticamente irrecuperables- limitó la excavación a la primera de las zonas citadas.

Esta actuación arqueológica ha permanecido totalmente inédita hasta la actualidad, por lo que se trata de la primera vez que se publican los datos del yacimiento, a excepción de los datos referidos al mismo en la Carta Arqueológica de San Fernando (Bernal et alii 2004, yac. $\mathrm{n}^{\circ}$ 16), un estudio arqueome'tricos de las ánforas reutilizadas en su construcción (Bernal et alii 2004 b) y algunas referencias indirectas (Alonso, Gracia y Menanteau 2003 a; Alonso, Gracia y Benavente 2004).

A continuación procedemos a realizar una valoración de las estructuras aparecidas y de la problemática estratigráfica del yacimiento, incluyendo al final del apartado una valoración del mismo.

El primer día de actuación se procedió a delimitar la ya mencionada cuadrícula de 5 x 2 m planteándose ésta englobando el afloramiento de ánforas que propició el hallazgo. A continuación se procedió a la cuadriculación en sectores de 2 x $1 \mathrm{~m}$ subdividiendo el cuadro principal, y aunque en un primer momento se pensó excavar estas cuadrículas de manera alterna, debido a las dificultades meteorológicas durante la excavación se decidió finalmente excavar el cuadro en extensión. La cota del terreno a partir de la cual se comenzó a excavar -interfaz superior- presentaba una pendiente descendente desde la cota superior del contiguo muro de acarreo de la salina, con unos $30^{\circ}$ de desnivel medio.

Tras la excavación de la zona se procedió al planteamiento de la secuencia estratigráfica, que quedó definida por tres niveles naturales, cuyas características definimos a continuación:

- U.E. 1: Suelo actual del muro de acarreo de la salina, formado por diversos materiales de escombro resultado de rellenos antrópicos moderno-contemporáneos, con una potencia escasa de unos

3. Se conserva en el Archivo del MHMSF el "Acta del hallazgo de piezas arqueológicas", fechada el día 14 de febrero de 1996 (Diligencias 2/96 de la 231 Comandancia de la Guardia Civil en Cádiz -Puesto de San Fernando-), en la que se detallan los hallazgos aparecidos y el depósito de los mismos en la mencionada institución días después.

4. Toda la información sobre la mencionada actuación arqueológica se encuentra depositada en los archivos del MHMSF, por lo que los datos empíricos que a continuación vamos a presentar proceden de la interpretación del Cuaderno de Campo conservado en esta institución. A continuación se intercalan los datos del citado diario de excavación con los procedentes del estudio directo del yacimiento por parte de los firmantes con motivo de la ejecución de la Prospección Arqueológica Superficial para la elaboración de la Carta Arqueológica de San Fernando en el año 2002. 
15-20 cms, con un incremento de la misma hacia el norte del corte, y con una coloración parda-anaranjada. Totalmente estéril desde un punto de vista arqueológico.

- U.E. 2: Estrato conformado por un nivel de gravas y cantos de pequeño y mediano tamaño mezclados con fango, de textura arenosa y coloración marrón muy oscura. Se trataba de guijarros basálticos y esquistos no autóctonos, traídos especialmente por su carácter drenante, al no ser litologías propias de la zona. Estas gravas se disponían creando un plano inclinado de unos $25 / 30^{\circ}$, generando una superficie de tendencia oblicua, si bien intuimos que dicha tendencia responde a la interfaz de destrucción del nivel, como se puede apreciar en la figura $3 \mathrm{~A}$, debiendo ser originalmente plana o, al menos, de tendencia horizontal. Se encontraban intercalados entre los guijarros algunos fragmentos cerámicos -eminentemente anfóricos- de reducidas dimensiones. La potencia de este estrato era de unos $15 \mathrm{cms}$ de media. Debido al elevado grado de arrasamiento de la estructura, esta pavimentación únicamente se conservaba en la zona más septentrional de la trinchera, coincidiendo con las denominadas Cuadrículas I y II (figura 3 A). A partir de este punto la misma se encontraba alterada, como resultado del descenso de cota fruto de la pendiente de la zona de excavación.

- U.E. 3: Conscientes de la existencia de unas alineaciones de ánforas localizadas bajo los estratos anteriores, que fueron las que propiciaron la actuación arqueológica, se excavó con gran atención la zona en cuestión, habiendo definido dos subniveles durante el trabajo de campo:

- U.E. 3 A: estrato similar al superior, con la diferencia de que las gravas bajan de cota y se mezclan con el fango pardo-grisáceo del substrato propio de la marisma, situándose este nivel en la superficie de contacto con los niveles de deposición de ánforas y entre las propias hileras formadas por ellas.

- U.E. 3 B: estrato compacto de fangos grises característicos de este entorno de marisma salinera en el que se encontraba la estructura hallada, teniendo una gran potencia, cercana al metro.

Durante la primera jornada de la actuación arqueológica se procedió a la retirada de los dos primeros niveles (UU.EE. 1 y 2), documentándose bajo la U.E. 3 A una hilera de ánforas horizontales de similar orientación a las afloradas casualmente, todas ellas en un estado muy fragmentario, salvo los ejemplares situados más al sur (figura 3). Asimismo en el sedimento procedente de los dos niveles superficiales aparecieron multitud de fragmentos cerámicos de diverso tamaño y origen relacionados con el depósito estudiado, de lo que se dedujo que la mayor parte de ellos debieron proceder de la rotura y disgregación de los ejemplares anfóricos de la hilada superior de ánforas, afectadas tanto por procesos posdeposicionales como por puntuales actuaciones antrópicas realizadas recientemente. En este último sentido, es conveniente indicar el negativo dejado por una hilada completa de ánforas en la U.E. 3 B, testimonio de un expolio realizado con anterioridad al inicio de la excavación arqueológica.

La excavación de la primera hilada de ánforas permitió documentar que todas ellas se encontraban unidas entre sí, con los pivotes engarzados en la boca de la siguiente. El estudio de las dos hileras que con seguridad existieron, pues de ellas se pudieron excavar algunos ejemplares completos, permitió plantear una alternancia en su orientación, de manera que la situada más hacia el oeste presentaba las bocas hacia el sur, mientras que la localizada en la zona central del sondeo estaba orientada exactamente al contrario. Esta apreciación pudo ser confirmada cuando se intervino en el nivel inferior de la estructura. Al aflorar algunas de las hileras del nivel inferior de la estructura, se concluyó confirmando la existencia de al menos otras dos hileras inferiores, que confirmaron que al menos nos encontrábamos ante una estructura con 4 hileras anfóricas alternantes en disposición horizontal. 


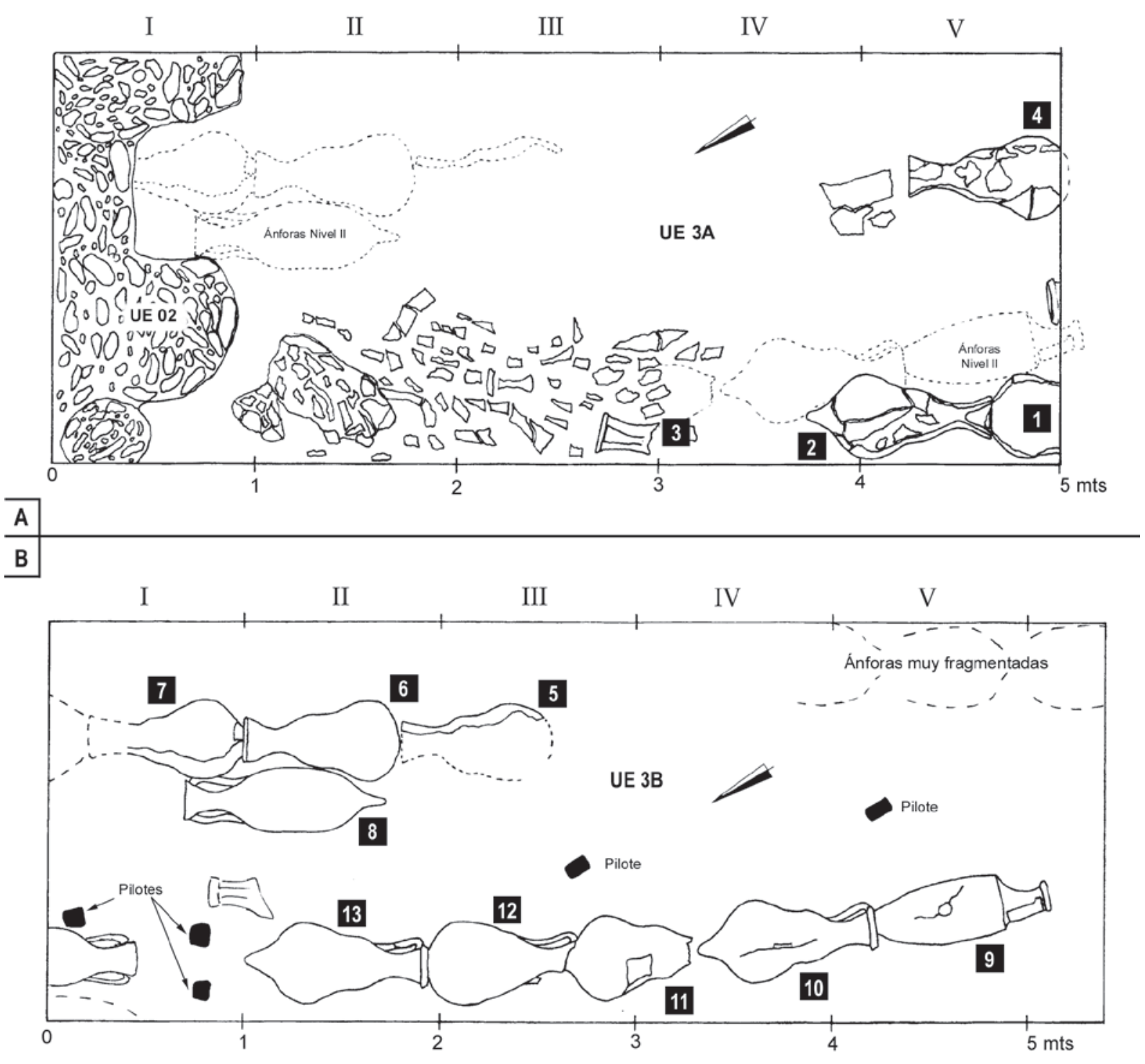

Figura 3.- Planimetría de la estructura de Los Cargaderos. A. Nivel Superior, con indicación del pavimento (U.E. 2), de las hiladas superiores de ánforas (U.E. 3 A, en trazo continuo), y de las localizadas en la hilada inferior (U.E. 3 B, trazo discontinuo). B. Nivel Inferior, con indicación de las hiladas inferiores (U.E. 3 B) y de los pilotes/estacas de madera (rectángulos negros).

La notable intensidad de las lluvias no permitió una correcta consecución de los trabajos arqueológicos, limitándose las actividades en la siguiente jornada a la creación de un canal de desagüe con el objeto de evacuar el agua estancada en la zona de excavación, tratando de evitar la mínima alteración del registro arqueológico infrayacente. A pesar de dichas precauciones, la cercanía del nivel freático y la intensidad de las aguas pluviales impedían la continuación de los trabajos arqueológicos, por lo que se tuvo que recurrir al uso de una bomba para el desalojo hídrico. Tras la retirada del agua y la limpieza de los restos superficiales que habían estado en contacto con las lluvias, se procedió al levantamiento de las 


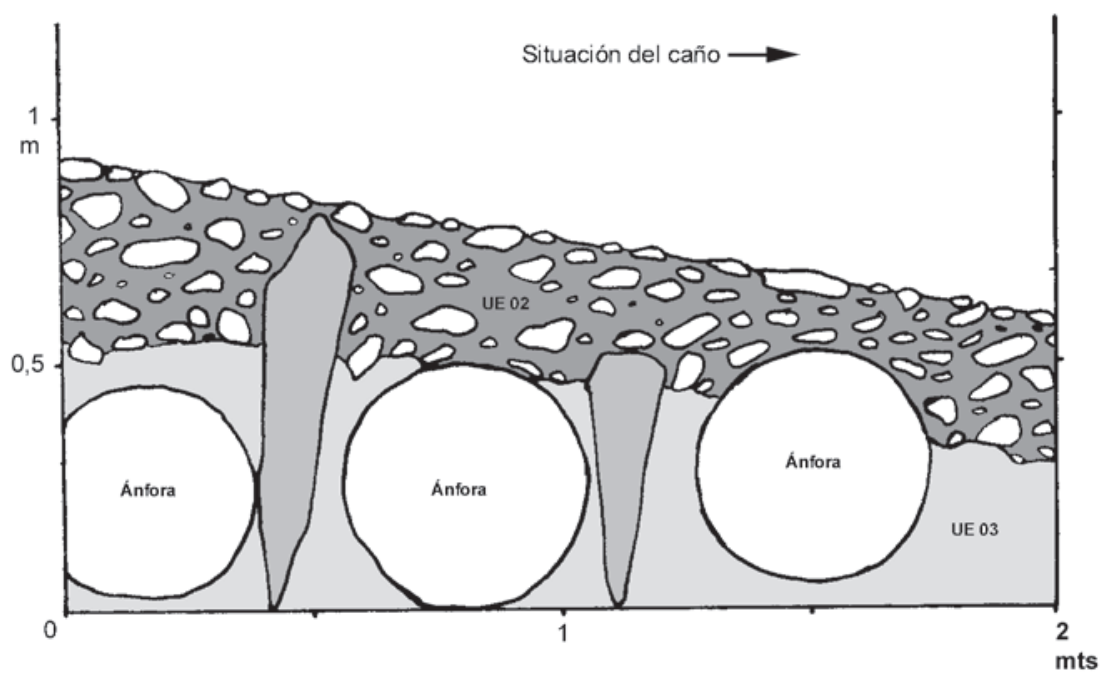

Figura 4.- Sección esquemática (Este-Oeste) de la estructura a la altura de la Cuadrícula I, con indicación de las estacas entre las hileras de ánforas, bajo el nivel de pavimento (realizada sobre un croquis original).

ánforas documentadas en el NIVEL SUPERIOR (U.E. 3 A), hecho que permitió poner al descubierto la continuidad de las ánforas, también en disposición horizontal, en lo que se definió como NIVEL INFERIOR (U.E. 3 B). Asimismo se continuó con la excavación de los primeros niveles en el resto del sondeo, localizándose una nueva hilada de ánforas en las Cuadrículas III y IV algo desplazada con respecto a las anteriores (figura $3 \mathrm{~B}$ ).

Las ánforas localizadas en las Cuadrículas I, II y III en la U.E. 3 B se disponían de similar manera que las restantes, machihembradas unas con otras, notándose también en esta ocasión un desplazamiento de los envases como consecuencia del movimiento del substrato geológico, curvándose en su extremo meridional.

Por último, debemos destacar el excepcional hallazgo de varios pilotes de madera situados entre las hiladas de ánforas, clavados verticalmente, de los cuales fueron documentados durante el proceso de excavación 5 ejemplares al menos, cuya posición se indica en la figura 3 B. Su situación en vertical y su disposición entre las alineaciones anfóricas permitían intuir una clara relación entre todos los elementos estructurales. Se procedió a la excavación de uno de los pilotes (fragmento 01), por lo que se pudo obtener una indicación de su posición -clavado en el fango-, con su extremo inferior apuntado, y su relación con los otros para la contención de las hileras de ánforas, impidiendo su desplazamiento horizontal (figura 4).

No obstante, para evitar cualquier duda al respecto y que nos encontrásemos ante los restos de estacas lígneas clavadas con posterioridad sobre el asentamiento romano, en una línea continuista bien conocida en la bahía gaditana -mantenimiento de los embarcaderos de madera en los mismos lugares, mediante refuerzo y/o adición de nuevas estructuras-, se planteó proceder a la datación absoluta de una de las muestras $\left(\mathrm{n}^{\circ} 01\right)$, cuyos resultados confirmaron su cronología romana, ofreciendo una datación entre el 110 a.C. y el 130 d.C., fecha calibrada con 2 Sigma, al 95\% de probabilidad (Anexo II).

Las características de las cuatro piezas lígneas recuperadas son las siguientes (figura 5):

Fragmento 01.- Pilote de madera cuyas dimensiones medias son 75,5 x 18,6 x 9 cms, de sección aproximadamente rectangular, aristada, con una de las caras anchas perfectamente alisada y trabajada, mientras la contraria se encuentra más deteriorada e irregular. Uno de los extremos se encuentra fracturado, denotando una mayor longitud original de la pieza, mientras el contrario fue trabajado hasta otorgarle 

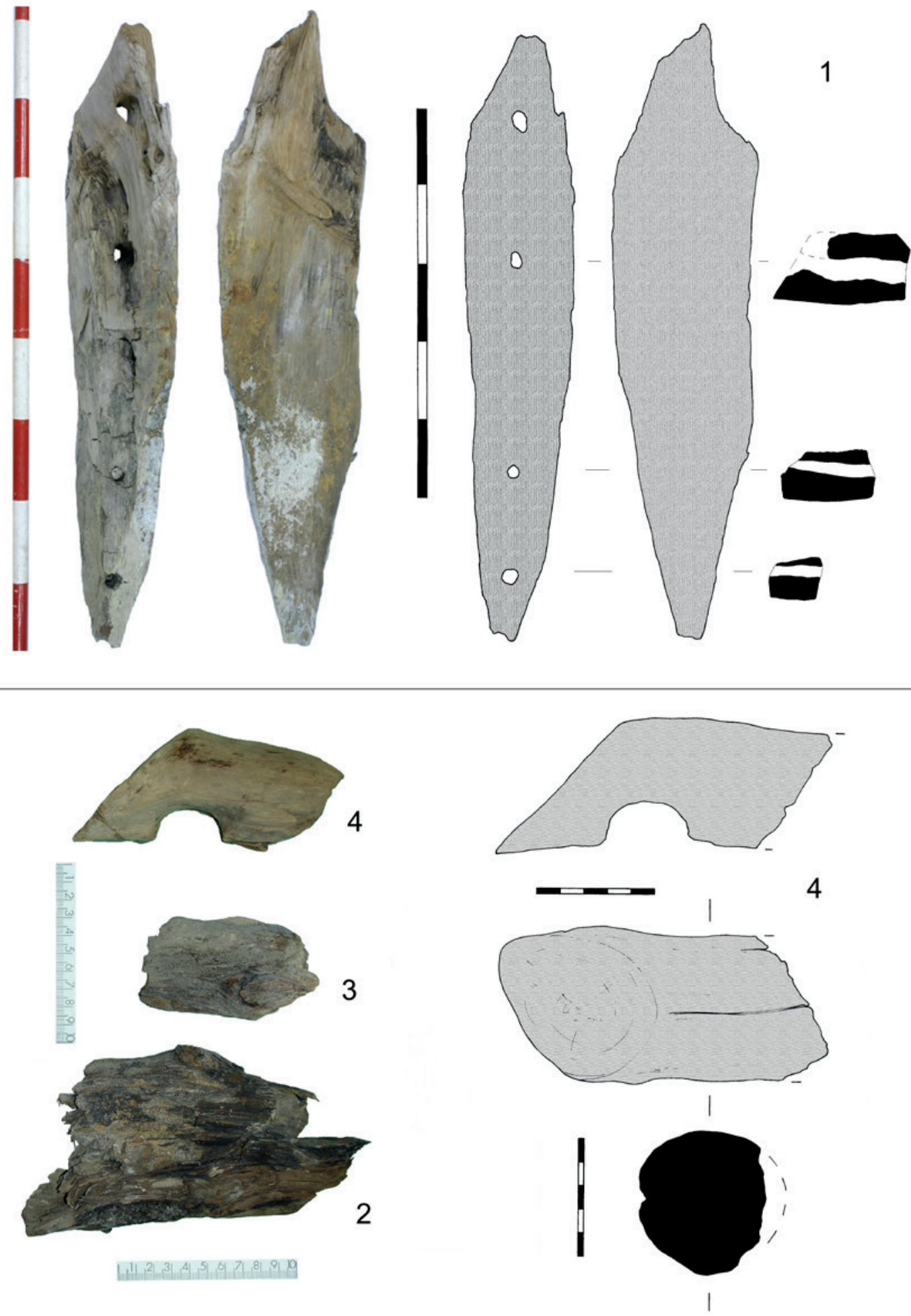

Figura 5.- Fotografías y dibujos de las cuatro pilotes de madera conservados, con detalle de las perforaciones equidistantes en el ejemplar 01, y las muescas en el 04. 
una forma muy apuntada con objeto de facilitar la operación de clavarlo en el terreno. Se aprecian aún a simple vista las huellas de las herramientas de carpintería, especialmente en la zona apuntada y en las caras más lisas y aristadas. Como elemento singular cabe citar la presencia de cuatro perforaciones de diámetro variable (entre 1,8 y 2,5 cms) dispuestas a lo largo de la pieza atravesándola totalmente todas ellas. En una de ellas se encuentran aún restos de una posible cuerda o de una pequeña pieza de encaje también de madera.

Fragmento 02.- Fragmento de un pilote presumiblemente de sección circular, de aproximadamente 18,3 de longitud y unos 8,7 de diámetro, conservando cerca de la mitad del mismo. Se trata de un pequeño tramo de la zona media de un pilote, en el que no se aprecian muescas, cortes o perforaciones, encontrándose muy deteriorado superficialmente, con adherencias propias de haber estado clavado en el fango marismeño.

Fragmento 03.- Pequeño fragmento lígneo ( 9 x 4,8 cms aprox.) perteneciente sin duda a uno mayor que se encuentra bastante deteriorado, con signos evidentes en una de sus caras de haberse desgajado de otra madera, quizá similar al pilote 01 . Lo reducido del fragmento permite especular demasiado, si bien parece presentar sección pseudo-cuadrangular, sin evidencias de muescas, cortes o perforaciones.

Fragmento 04.- Fragmento de madera de color marrón claro, ocre, de unos 14,5 cms de longitud y $6,7 \mathrm{cms}$ de anchura. Se trata aparentemente del extremo de un palo de mucha mayor longitud, fracturado en uno de sus extremos y cortado con precisión por el contrario, dejando dicha zona con un aspecto apuntado quizá con la finalidad de que penetrase mejor en el barro de marisma donde se insertaba. Como el fragmento número 02, presenta una sección pseudo-circular pero de menor diámetro, contando además con una peculiar muesca junto al extremo apuntado que le otorga un aspecto denticulado.

De la disposición que presentan las estacas (figuras 3 y 4), podemos extraer una serie de conclusiones. El número de estacas de madera debió ser numeroso, pues únicamente en la zona excavada se documentaron 5 ejemplos, además de otros dos más hacia el este, respectivamente en los cuadros 7 y 8. Se detecta la existencia de una alineación con claridad, caso de todas las ilustradas a excepción de la de mayores dimensiones (figura $3 \mathrm{~B}$ ). Al situarse la misma entre varias hileras de ánforas, parece evidente que la empalizada no constituía el final de la estructura, como luego veremos en los ejemplos de la laguna de Venecia. En esta ocasión parece que las estacas estaban destinadas a dotar de solidez a la estructura, evitando el basculamiento de las ánforas hacia los laterales. En esta misma línea interpretativa cuadraría el hallazgo de otras estacas desplazadas (como la ilustrada por el fragmento 01), que constituirían refuerzos transversales. Por último, y como se advierte en la sección dibujada, perpendicular al eje del sondeo (figura 4), las estacas se situaban exactamente entre las hileras anfóricas y, además, fueron clavadas previamente a depositar la capa de cantos y gravas, como testimonia el ejemplar de menores dimensiones, de lo que se deduce que la altura total de la estructura no superaba $\operatorname{los} 2 \mathrm{~m}$ de potencia.

Destacar que en los cuatro casos estudiados nos encontramos ante ejemplares pertenecientes a madera de pino, como resulta del análisis arqueobotánico realizado sobre todas las muestras (Anexo I), al tiempo que al menos dos de ellas (Fragmentos 01 y 04) muestran evidencias de retalles que inducen a pensar bien en el hecho de que nos encontramos ante maderas reutilizadas, bien que existió un sistema de ensamble entre ellas que no ha dejado testimonio arqueológico alguno. No olvidemos que las dimensiones de las piezas son claramente divergentes, por lo que la primera de las dos posibilidades parece la más factible. En cualquier caso, parece que no nos encontramos ante 
elementos reutilizados de arquitectura naval, al menos de piezas primarias del casco de algún barco 5 . Esta situación no es de extrañar, pues las únicas instalaciones portuarias en madera bien conservadas en Hispania, las del muelle de Oiasso (Irún), presentaban abundantes vigas de construcción, estacas y elementos de tonelería reutilizados para el relleno de la cimentación de los edificios portuarios (Urteaga 2003, 200). Únicamente plantear como posibilidad, al hilo de los citados hallazgos de Irún, respaldados por los que luego veremos en la laguna de Venecia (Fozzatti y Toniolo 1998), que tal vez tras estos restos con evidencias de perforaciones horizontales (fragmentos 01 y 04), que además son paralelas y en número de 4 en el ejemplar de mayores dimensiones, puedan esconder tras de sí los restos de un "tablestacado", es decir un panel de madera configurado por tablas horizontales clavadas a postes verticales, como sí se ha documentado con nitidez en ambos casos citados. O bien que existiese dicha estructura lignea de contención en los extremos del muelle, que no hay sido excavada, la cual estaría configurada con postes sobre los que apoyaban tableros creando un cierre perimetral sólido. Desgraciadamente, la parquedad de los testimonios aparecidos no permite, por el momento, mayores precisiones al respecto.

Mencionar que con posterioridad a la finalización de la actuación arqueológica se han vuelto a producir hallazgos casuales en la zona, como sucede con una de las ánforas selladas incluidas en este estudio (figura 12, $\mathrm{n}^{\mathrm{o}} 32$ ).

\subsection{Interpretación funcional de Los Cargaderos. Un embarcadero romano a orillas del Caño de Sancti Petri.}

La actuación arqueológica desarrollada en Los Cargaderos permitió la documentación de una estructura constructiva realizada con ánforas cuyas características básicas debieron ser las que presentamos a continuación:

Estratigrafía (de techo a base):

- Pavimento superior: realizado con cantos y guijarros alternantes con escasos fragmentos cerámicos. El aglutinante era el propio fango de marisma de lo que se deduce una ausencia de intencionalidad para dotar a la estructura de estanqueidad. Una característica que se deriva de lo anteriormente expuesto es el carácter drenante de dicha pavimentación, ante su ausencia de impermeabilización (no recurrencia al uso de signinum, técnica muy abundante en la edilicia gaditana desde época tardorrepublicana). Por otro lado la total ausencia de estructuras sobre el mismo converge en plantear su interpretación como una estructura pavimental.

- Nivel Superior de ánforas: se han conservado restos de dos alineaciones en el nivel superior, que denominamos respectivamente Alineación 1 y 2 (figura 6).

- Alineación 1 (figura 3 A): se sitúa en la zona más occidental del corte, conservándose testimonios de las ánforas que la compusieron a todo lo largo de su superficie. Concretamente dos ánforas casi completas en la zona suroeste $\left(n^{0} 1 \text { y } 2\right)^{6}$ y un conjunto de materiales fragmentados en la zona central y septentrional, de las cuales únicamente ha sido posible individualizar un

\footnotetext{
5. Según las indicaciones de D. C. León Amores, derivadas de la visualización directa de las piezas. No obstante, no descartamos que hubiesen formado parte de otros elementos lígneos de una embarcación, al coincidir que es la madera de pino una de las más abundantes en la arquitectura naval romana.

6. Únicamente se numeran aquellos ejemplares que ha sido posible identificar formalmente y localizar en las dependencias del MHMSF. Como se puede apreciar en las ilustraciones 3 y 4 se documentan fragmentos de muchos más ejemplares descohesionados anatómicamente.
} 
ejemplar $\left(n^{\circ} 3\right)$. A tenor de los dos únicos ejemplares conservados, la orientación de las ánforas era con las bocas hacia el sur.

- Alineación 2 (figura 3 A): se sitúa en la zona central del corte, algo desplazada hacia el este. Se conserva únicamente el perfil completo de un ejemplar $\left(n^{\circ} 4\right)$, orientado con la boca hacia el norte.

— Nivel Inferior de ánforas: se han preservado más restos que en el caso anterior, derivados de su situación a mayor profundidad y, por tanto, de la menor afección a los agentes metereológicos y antrópicos. Se conservan testimonios de tres hiladas horizontales de ánforas (figura 6):

- Alineación 3 (figura 3 B): se localiza en el tercio oriental del corte, caracterizándose por integrar a tres ánforas salsarias embutidas entre sí ( $\mathrm{n}^{\circ}$ 5-7), con las bocas hacia el norte.

- Alineación 4 (figura $3 \mathrm{~B}$ ): se sitúa prácticamente en la zona intermedia del corte, y está constituía por un único ejemplar ( $\left.n^{\circ} 8\right)$, también con la boca orientada al norte, como en el caso anterior.

- Alineación 5 (figura $3 \mathrm{~B}$ ): es la hilera más completa de todas las conservadas, integrando a cinco individuos completos ( $\mathrm{n}^{\circ} 9$ a 13). Las bocas están orientadas hacia el sur. Se encuentra algo desplazada de su trayectoria original en su tramo más meridional, habiendo basculado los dos últimos ejemplares $\left(\mathrm{n}^{\circ} 9\right.$ y 10$)$ hacia el este.

A tenor de estos datos podemos plantear la propuesta de reconstrucción de la estructura de drenaje hallada en Los Cargaderos (figura 6).

- Dimensiones totales: desconocidas, pero al menos de $10 \mathrm{~m}^{2}(2 \times 5)$, coincidiendo con la totalidad de la superficie de la zona de actuación arqueológica. Su continuidad hacia los cuatro puntos cardinales está confirmada por los hallazgos arqueológicos más allá de los límites de la trinchera excavada. Hacia el norte, este y oeste la continuación del perímetro de la pavimentación de guijarros (figura $3 \mathrm{~A}$ ). Y hacia el sur por las ánforas del Nivel Superior $\left(\mathrm{n}^{\circ} 1\right.$ y 4$)$ que se introducen en el perfil meridional (figura $3 \mathrm{~A}$ ).

- Infraestructura, compuesta por alineaciones de ánforas, cuyas características son básicamente su disposición horizontal, en cinco hiladas paralelas al menos en cada una de las dos alturas. Permiten reconstruir tal propuesta las dimensiones vacantes existentes al oeste de la Alineaciones 2 y 3 y el situado entre las Alineaciones 4 y 5 , en ambos casos con anchuras casi exactas para un ánfora. Este hecho unido a la coincidencia en altura de los ejes de las hiladas anfóricas (Alineaciones 2-3 y 1-5) permite restituir el conjunto excavado compuesto por cinco hileras de ánforas en dos alturas, situadas unas exactamente sobre las otras, no en alternancia (figura 6 , infra). Además, en sentido horizontal parecen situarse al tresbolillo, como se deduce de la relación entre las ánforas 6-7 y 8, yuxtapuestas de manera que el plano del cuello de una de ellas coincide con la parte ventral central de las de la siguiente hilera. No obstante, esta cuestión no debe ser tomada a rajatabla, pues las diferencias métricas entre unos y otros ejemplares probablemente obligaron a encastrar las ánforas no manteniendo parámetros estructurales precisos. Otro aspecto que planteamos es la orientación de las hiladas, claramente alternante a tenor de la situación de algunas de ellas con las bocas hacia el norte (Alineaciones 2, 3 y 4) y otras hacia el sur (Alineaciones 1 y 5). Parece que van ordenadas al menos por partes, como se desprende de la yuxtaposición de las Alineaciones 3 y 4, ambas con las bocas hacia el norte. Y también sabemos que aparentemente las orientaciones no cambian en función del nivel en el que estemos, pues en los dos únicos casos conservados (Alineación 1-5 y 2-3) la dirección es la misma. El ritmo en el cambio de orientación es el dato hipotético, pues no sabemos si es doble o triple, 
Figura 6.- Interpretación funcional de la estructura de Los Cargaderos.

encontrándose ambas posibilidades presentes. Por otro lado, las hiladas estarían reforzadas entre sí por hileras de palos intermedios, como se deduce del hallazgo de algunos postes durante el proceso de excavación, a nuestro juicio destinados a evitar el desplazamiento de las hileras como vemos que sí ha sucedido en el caso de la Alineación 5, posiblemente con posterioridad al abandono de la estructura. Como veremos con posterioridad, es muy probable que la estructura excavada en Los Cargaderos tuviese unas empalizadas de refuerzo laterales, guiados por los paralelos hallados en Oderzo, que luego comentaremos detalladamente, si bien de dichos potenciales restos no se ha conservado traza arqueológica alguna.

En algunas de las ánforas se ha detectado la existencia de orificios realizados intencionalmente a la altura de la panza, de dimensiones variables. Se conservan al menos tres ejemplares que testimonian esta práctica (Catálogo no 1, 3 y 29 -Anfora 9 de la Alineación 5-), si bien posiblemente más ánforas debieron contar con ellos, como se aprecia en algunas roturas curvilíneas de algunos fragmentos de galbos. Su realización permitiría la evacuación de agua con mayor rapidez en el caso de elevada presencia -fuertes lluvias...-. Se trata de una práctica conocida en este tipo de estructuras de drenaje. Conocemos ejemplos de estructuras de bonificación en las cuales las ánforas presentan orificios, caso de la fosas de drenaje documentadas en las excavaciones de la Universidad Católica de Milán (Bruno 1998: 260-262 y fig. 2).
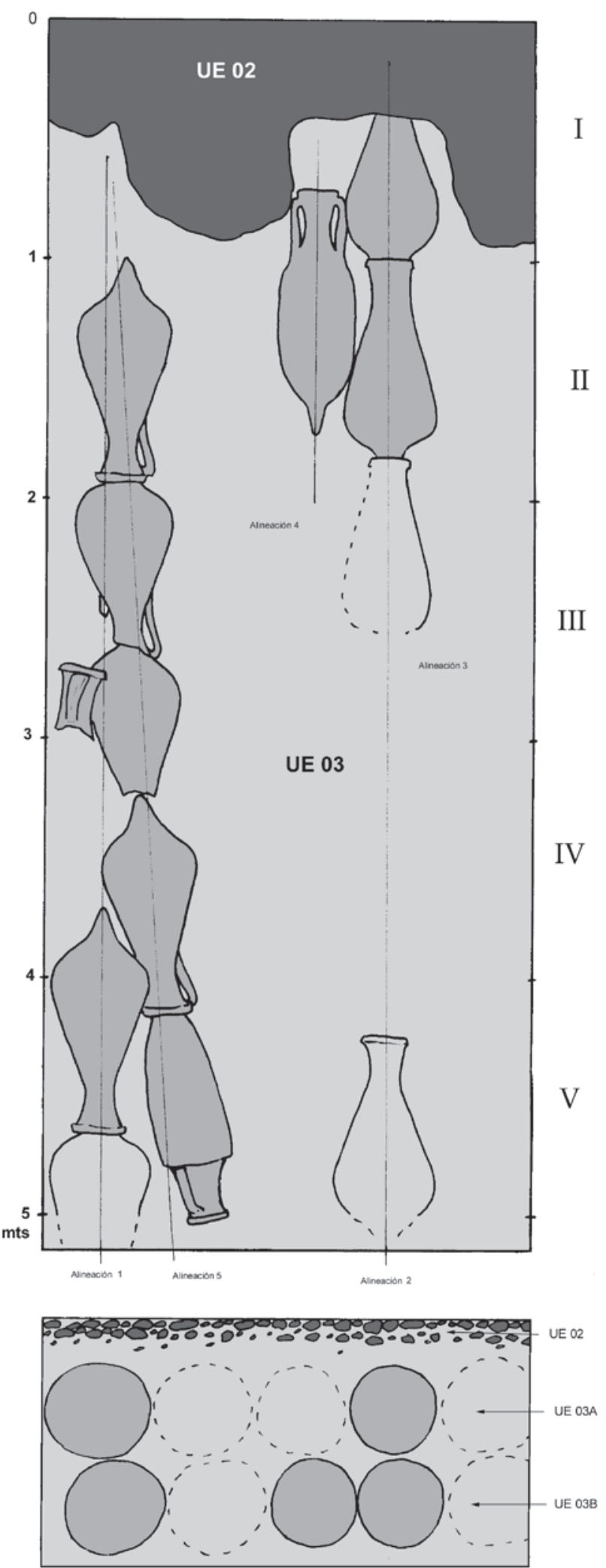


\subsection{Paralelos e interpretación del complejo. Valoración funcional y reflexiones.}

Una vez realizado el desglose analítico de los restos aparecidos en Los Cargaderos es el momento de proceder a su contextualización mediante el estudio combinado de otros ámbitos mediterráneos. Para ello son tres los aspectos en los cuales consideramos fundamental incidir: el uso de madera, la interpretación del depósito anfórico y la funcionalidad del pavimento de cubrición de la estructura.

\subsection{1.- La arquitectura lignea en las estructuras fluvio-marítimas.}

Una primera cuestión que debe ser tenida en cuenta es la constatación de obras de carácter palafítico o al menos aquellas en las cuales se haya usado madera en época romana en la zona de estudio. No hace falta evocar a Vitrubio $(\mathrm{V}, 3, \mathrm{~V}, 6$ y V, 13) para recordar las construcciones portuarias con encofrados de madera. En ocasiones el uso de madera en las instalaciones portuarias ha sido utilizado como argumento indirecto para explicar el por qué de la parquedad edilicia de las estructuras portuarias, incluso en la Península Ibérica (Blackman 1990: 126).

Como veremos a continuación, ésta se convierte en una novedosa línea de investigación arqueológica para el futuro, pues existen indicios suficientes para plantear la importancia de la arquitectura lígnea en las estructuras portuarias romanas, si bien son exiguos los paralelos arqueológicos documentados por el momento en la Bética.

En Hispania la única referencia clara se limita a las estructuras portuarias de Oiasso -Irún-(Urteaga 2001 y 2003). Por un lado contamos con un sistema de estacas lígneas relacionadas con la cimentación de un puente sobre el curso del río Bidasoa, fechadas por C-14 entre el 17 y el 267 d.C. (Urteaga 2001). Y por otro, las excavaciones que ya llevan prácticamente una década en diversos solares de la antigua ciudad portuaria vasca han permitido exhumar los restos de una rampa para el calado de barcos, fechada entre el 70 y el 95 d.C. y en uso durante los ss. II y III d.C., conformada por una retícula horizontal de vigas de roble rellenas de material arqueológico, así como una escollera de piedra (Urteaga 2003: 198200). Y también los restos de un muelle de atraque en la zona de Tadeo Murgia compuesto por gradas con zócalo pétreo y huellas de madera, construido entre el 70 y el 120 y en uso únicamente durante el s. II d.C. (Urteaga 2003: 201-202).

Otros ejemplos hispanos serían posiblemente Hispalis y tal vez Olisipo, debiendo acudir a los grandes puertos del Mediterráneo y el Atlántico, tales como Londinium (Milne 1982, 1985 o más recientemente Marsden 1994), Marsella (Hesnard 1995), Pisa (Bruni 200 y 2003) y quizás Toulon (Pasqualini 2000) y otros ejemplos franceses e italianos entre los que se sitúa recientemente a Burdigala-Burdeos(Barraud 2003), Nantes o Fos-sur-mer para avanzar al respecto. Como veremos a continuación, dos zonas son las que ofrecen más paralelos tipológicos y funcionales para la estructura gaditana: el Norte de Italia y la desembocadura del Ródano.

Efectivamente, a tenor de los hallazgos localizados, en la Bética el paralelo más claro es el puerto de Hispalis (Ordóñez 2003). Las estructuras portuarias fluvio-marítimas de Sevilla, actualmente situadas a unos $185 \mathrm{kms}$. al interior, se localizaban en época romana en un amplio estuario fluvial de más de $5 \mathrm{kms}$. de anchura, de cuyo conocimiento quedan pocas evidencias. Se trata de hallazgos antiguos, recogidos y reinterpretados recientemente (Ordóñez 2003: 66). Nos referimos al hallazgo en la zona del Cine Imperial por F. Collantes de Terán de gruesos pilotes de madera de pino aguzados en su extremo inferior, de 1,5 m de longitud y clavados regularmente en el suelo arenoso, que este investigador interpretó como puntales de un sistema de cimentación y drenaje de edificios (Collantes 1977). También se reflejan en el citado trabajo de S. Ordóñez los hallazgos en 1960 en 
la Plaza de San Francisco (Carriazo 1974-1975: 96; 1980: 58-59), que según él también son relacionables con pilotes de embarcaderos romanos a lo largo de la orilla del cauce del río, siguiendo en esta hipótesis una propuesta anterior (Guerrero 1984: 96). Estos datos son interpretados, debido a su proximidad a la orilla del Guadalquivir y a su escasa distancia (apenas $400 \mathrm{~m}$ lineales entre el Cine Imperial y la Plaza de San Francisco) como los restos de un gran embarcadero en la margen izquierda del río (Ordóñez 2003: 67). Otros hallazgos tales como los del Patio del Cabildo, interpretados como un posible "malecón portuario" (Ordóñez 1998: 157) y algunos datos de recientes excavaciones, aún inéditos y conocidos únicamente por referencias (García, Alonso, Jiménez y Maclino 2004) permiten intuir un notable potencial a esta zona sevillana para el hallazgo de estructuras portuarias $-\mathrm{y}$ entre ellas elementos lígneos- en el futuro.

Por otra parte, en la propuesta de restitución del puerto de Baelo Claudia no se descarta la recurrencia a espigones de madera construidos sobre pilotes. Quizás testimonios de los mismos hayan sido hallados en las huellas de resistividad eléctrica en el estudio geoarqueológico recientemente realizado, como proponen los investigadores (Alonso et alii 2003b), aunque no deja de ser, por el momento, una hipótesis de trabajo. Por último, en la Bahía de Cádiz únicamente contamos con la referencia indirecta al hallazgo de estacas para la cimentación del acueducto de Gades, sin que se hayan realizado estudios monográficos al respecto (Alonso, Gracia y Benavente 2004: 272).

Evidentemente, los datos anteriormente comentados son únicamente indicios de una realidad andaluza mucho más compleja, de los cuales al menos se deduce la posible existencia de estructuras portuarias de madera de época romana, si bien esta línea de investigación se encuentra aún en estado embrionario.

En el caso de la Lusitania los datos son aún más escasos. Se ha planteado recientemente la importancia de la arquitectura lígnea en los puertos de Lisboa al menos desde el s. XVI en adelante, como demuestran los "cais" de madera del puerto lisboeta conocidos por grabados (Blot 2003: 113-114). Por el momento, las únicas estructuras lígneas recuperadas remiten a contextos de época moderna, en los cuales predominan las estacas de pino verde, como demuestran los hallazgos de la cimentación de la muralla de Peniche o las construcciones pombalinas de la Bahía de Lisboa (Blot 2003: 140). Es decir, una total ausencia de datos romanos por el momento, derivados posiblemente de problemas de conservación, si bien la tradición en la arquitectura naval permite plantear la hipótesis de su uso también durante época romana (Blot 2003: 22 y 90-91). Únicamente se menciona una cita antigua relativa al uso de madera en época antigua en la Rua Arco da Bandeira en Lisboa, y un posible "cais" romano en la misma ciudad (Blot 2003: 240), del cual únicamente se indica su localización en la Rua das Canastras (Amaro 1995: 13, supra). En los estudios más recientes sobre la fisonomía del puerto romano de Lisboa se ha propuesto la existencia de un puerto de estuario con malecones de atraque, posiblemente construidos en madera, al modo del gran puerto de Londinium (Mantas 2003: 25).

En fechas recientes se han documentados restos de carácter portuario en Port la Nautique, uno de los accesos portuarios a la ciudad de Narbo (Falguera, Bernard y Jezegou 2003). Se trata de una estructura portuaria construida en época augustea y destruida a mediados del s. I d.C. localizada a $150 \mathrm{~m}$ de la costa, realizada en aparejo pétreo, con sillares de grandes dimensiones encerrados por una empalizada de estacas de madera clavadas en el fondo hasta al menos 4,1 m de profundidad, sin uniones entre ellas y con un espesor de unos $34 \mathrm{cms}$. (Falguera, Bernard y Jezegou 2003: 203). Se trata de uno de los primeros hallazgos de estas características en ámbito portuario, recogiendo algunos ejemplos de muelles de piedra con empalizadas externas, entre los cuales cita Marsella -place Villeneuve/Bargemon- y los hallazgos antiguos en el Campo de Marte en Roma, citando en éste último caso la empalizada de estacas de roble (Falguera, Bernard y Jezegou 2003: 209), remitiendo 
al reciente trabajo de E. Felici para ampliar los datos (2001). De Roma son escasos los datos posteriores además del citado, pues si bien se conocen las construcciones de muelles ("banchine") a lo largo del curso del Tíber y los dos puertos fluviales más importantes -Ripa Grande y Ripetta-, no se referencian datos como el comentado de su técnica constructiva, ni tampoco abundan los hallazgos arqueológicos al respecto (Caprariis 2003).

Por su parte, el puerto de Aquileia es un ejemplo claro de instalación portuaria petrificada de casi $50 \mathrm{~m}$ de longitud, de la cual se conservan especialmente las "banchine portuali" realizadas con sillares unidos por grapas, y que daban acceso a la ciudad por medio de un sistema a base de rampas, conjunto todo él datado de mediados del s. I d.C. en adelante. Además, se citan los hallazgos de estructuras de madera clavadas en el fango, testimonio de antiguos embarcaderos, si bien son escasos los datos de detalle al respecto (Rosada 2003). Por citar un ejemplo reciente recordamos los recientes hallazgos lígneos en la Piazza San Rossore di Pisa, que ofrecen restos de espectaculares estructuras portuarias desde época etrusca a la Antigüedad Tardía (Bruni 2000 y 2003: 79-81).

Se documenta una tendencia implícita por considerar en las reconstrucciones de las estructuras portuarias la existencia de embarcaderos en madera, de los cuales, desgraciadamente no quedan restos. Las estructuras recientemente excavadas en Caesaraugusta son un buen ejemplo de ello, al haberlo planteado explícitamente en su propuesta reconstructiva (Aguarod y Erice 2003: 149).

Por todo lo comentado en este apartado, parece evidente la importancia del uso de la madera en las construcciones portuarias fluviomarítimas de las provincias occidentales del Imperio, debiendo atribuir únicamente a cuestiones de conservación su ausencia en el registro arqueológico. En España contamos con el paradigmático ejemplo de las estructuras portuarias de Irún a las cuales se unen, en su modestia, los restos documentados en el yacimiento de Los Cargaderos en la Bahía de Cádiz. Se trata en nuestro caso del primer ejemplo conocido de madera de época romana asociada a instalaciones portuarias publicado en Andalucía, cuya cronología y caracterización arqueobotánica están fuera de toda duda (Anexos I y II).

\subsection{2.- Estructuras drenantes con ánforas en ámbito mediterráneo. Problemática y paralelos.}

El uso de ánforas en sistemas de drenaje es una cuestión conocida especialmente en la zona de la laguna de Venecia y en el Valle del Po, siendo poco habitual en ámbito mediterráneo, a excepción del valle medio y bajo del Ródano, como veremos a continuación. Básicamente su utilización con finalidad drenante está vinculada a tres actividades fundamentalmente: saneamiento, drenaje o estabilización del suelo.

Los ejemplos conocidos, que superan el centenar, han permitido documentar una notable diversidad de situaciones, documentándose los envases en multitud de posiciones (horizontales, verticales, en diagonal o en disposición caótica), completas o con roturas a la altura del cuello, los hombros y con fracturas en el pivote, y vinculadas a obras públicas en ámbito urbano, periurbano y rural (asociadas a trama viaria, espacios productivos o infraestructura hidraúlica). Son actuaciones derivadas de un interés por el control del régimen hídrico de los suelos y de las formas de gestión de las aguas superficiales, especialmente habituales de época tardorrepublicana y altoimperial.

De ahí que una primera cuestión fundamental sea la comprensión técnica de los procesos de bonificación y drenaje para poder proceder a interpretar las instalaciones anfóricas documentadas, algo especialmente importante en el caso de la estructura recuperada en Los Cargaderos. Se han propuesto tres usos genéricos, que son los que reproducimos en la siguiente tabla (Lunardi 1998: 45-46, fig. 10). 
FunCiONALIDAD DE LAS INSTALACIONES ANFóRICAS DE DRENAJE (SEGÚN LUNARDi 1998)

\begin{tabular}{|c|c|c|}
\hline Actuación & Objetivo & Resultado \\
\hline Protección anticapilar & Evitar la subida de la humedad & Ánforas enteras y al revés \\
\hline Drenaje por captación & $\begin{array}{c}\text { Facilitar la evacuación de aguas } \\
\text { superficiales }\end{array}$ & $\begin{array}{c}\text { Ánforas horizontales o inclinadas, embu- } \\
\text { tidas unas en otras }\end{array}$ \\
\hline Aligeramiento & $\begin{array}{c}\text { Equilibrar el peso de construcciones } \\
\text { superiores (isostasia) }\end{array}$ & Diverso \\
\hline
\end{tabular}

Otros autores proponen separar las actuaciones de drenaje de las relacionadas con el saneamiento preventivo del terreno y/o edificaciones, de tal manera que las situaciones hidrogeológicas posibles serían dos: evitar las aguas que suben del freático y permitir la evacuación de las aguas superficiales fluviales y pluviales- (Balista 1998: 24 y 26).

Algunos investigadores se han preguntado el por qué del uso de ánforas para estas construcciones y no arena y/o grava, siendo la razón evidente: crear una cámara de aire (Gallina 1998: 73). Los envases se disponen horizontalmente porque así presentan mayor superficie, y por ello hay una menor presión de la carga que tienen encima. Sirven asimismo para evitar la tendencia natural a la compactación del terreno. Y debido a su reducido peso específico al disponerlas horizontalmente ejercen poco peso hacia abajo y mucha capacidad portante (Gallina 1998: 74-76).

Una vez aclarados los condicionantes técnicos anteriormente citados, vamos a proceder a realizar una sucinta presentación de los principales paralelos que hemos documentado de este tipo de estructuras en ámbito mediterráneo, teniendo en cuenta únicamente las estructuras de drenaje con ánforas en posición horizontal, que son mucho menos frecuentes, pero al menos ascienden a más de una treintena de ejemplares, que detallamos a continuación (figura 7).

Comenzando por Italia, la mayor parte de ejemplos se concentran en las regiones véneta y padana. Por un lado Milán, lugar en el cual se documentaron alineaciones en posición horizontal, encastradas unas en otras, sin más datos al respecto (Lunardi 1998: 46), a las que debemos unir las estructuras de bonificación excavadas en la Università Cattolica (Bruno 1998: 260-262). En Padua, se conocen los saneamientos preventivos de ánforas en disposición horizontal o tenuemente inclinadas, y además encastradas "bocca-puntale", dentro de fosas de drenaje en la zona de la Necrópolis delle Brustolade (Balista 1998: 24).

El caso de Altino es uno de los mejor conocidos, por cuanto se tiene constancia de "banchi d'anfore" en ámbito urbano, periurbano y suburbano, con unos 40 hallazgos conocidos en la actualidad, que se relacionan con obras de drenaje y consolidación en ambientes funerarios, en las vías y en el campo limítrofe, en unas fechas normalmente de la segunda mitad del s. I a.C. o de la primera mitad del s. I d.C. (Tirelli y Toniolo 1998: 87-100). De todos los ejemplos existentes en Altino, los más cercanos son los siguientes. Por un lado una estructura del último tercio del s. I a.C. situada en la necrópolis noreste de la via Annia, compuesta por tres hileras paralelas de ánforas hincadas verticalmente al revés (con unas dimensiones de $14 \times 1,5 \mathrm{~m}$ ), en la cual se realiza una ampliación posterior consistente en la colocación de ánforas en disposición horizontal (Tirelli y Toniolo 1998: 91 y 93-94, n² 22). Otro cercano paralelo, tanto en dimensiones como en posible funcionalidad (=actividad en la zona superior) es una estructura de finales del s. I a.C. realizada con ánforas horizontales dispuestas en dos estratos, estando las más grandes cortadas a la altura del cuello, conteniendo otras menores: posiblemente se trata de la cimentación de una habitación, pues sobre la parte superior se recuperaron multitud de "lacerti d'intonaco dipinto" (Tirelli y Toniolo 1998: 97-98). Por último, insistir en la frecuencia de este tipo de estructuras utilizadas como elementos 


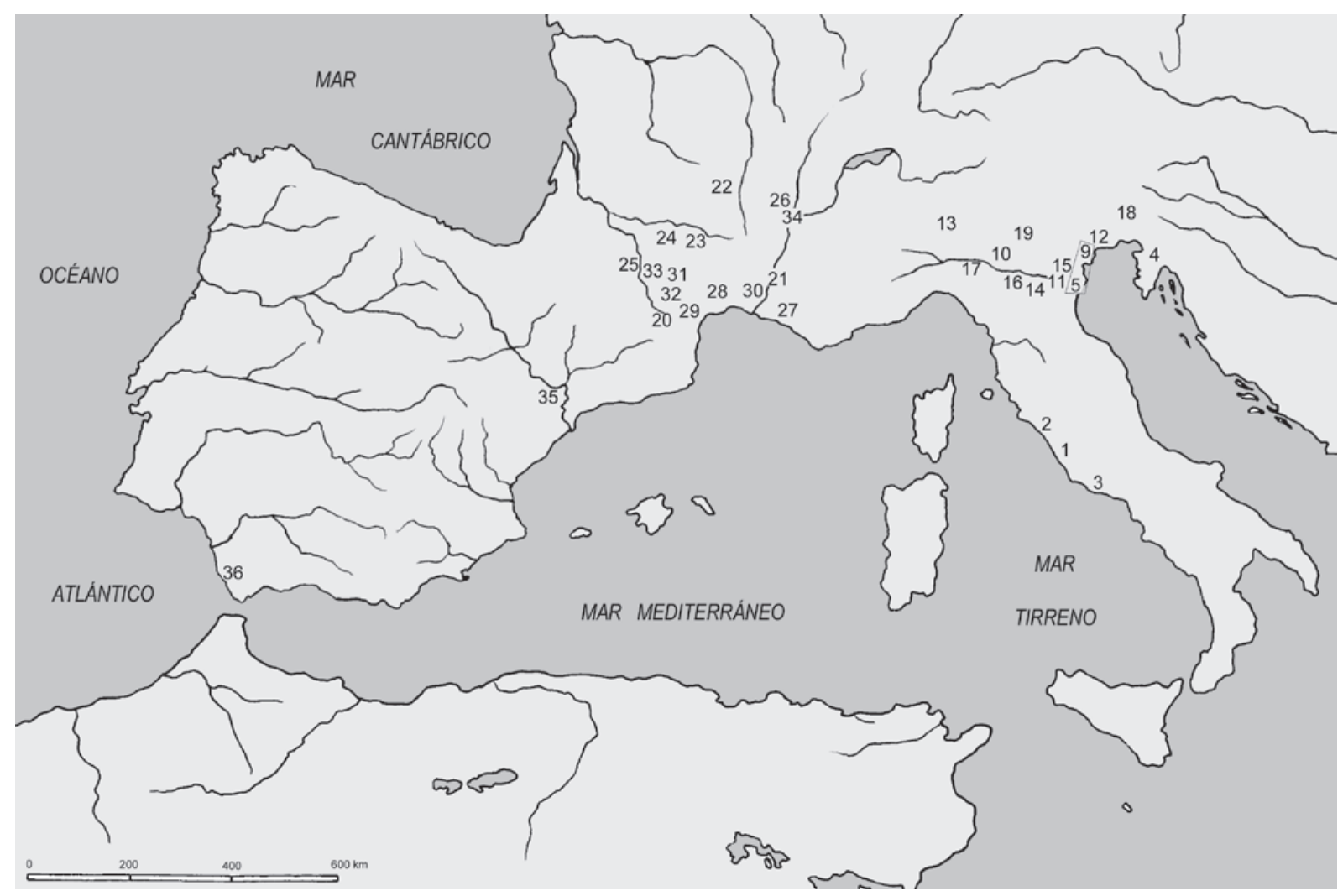

Figura 7. Mapa de distribución de los sistemas de drenaje con ánforas en el Mediterráneo Occidental (según Pessavento 1998, con adiciones propias). Italia mediterránea: 1.- Ostia; 2.- San Gaetano di Vada (Rossignano Marítimo); 3.- Terracina -Sperlonga; 4.- Val San Pietro -Pula. Norte de Italia: 5.- Adria (Rovigo); 6.- Altino; 7.- Aquileia; 8.- Cavaltone (CR); 9.- Concordia Sagittaria (Venecia); 10.- Cremona; 11.- Este (PD); 12.-Laguna de Venecia; 13.- Milán; 14.- Oderzo (TU); 15.- Padua; 16.- Parma; 17.- Piacenza; 18.- Sevegliano y Codroipo -Friuli-; 19.- Verona. Francia: 20.- Bibracte; 21.- Carpentras; 22.- Clermont-Ferrand; 23.- Cordes (Tarn); 24.Châteaumeillant (Cher); 25.- Fréjus; 26.- Lyon; 27.- Marsella; 28.- Monfo (Magalas, Hérault); 29.-Narbonne; 30.Nimes; 31.- St-Romain-en-Gal; 32.- Ste. Colombe; 33.- Vielle-Toulouse (Haute-Garonne); 34.- Vienne. España: 35.- Zaragoza; 36.- Los Cargaderos.

de contención de los laterales de las vías, o bien a modo de diques para reforzar las orillas de los cursos fluviales (Tirelli y Toniolo 1998: 101-104). El ejemplo de Altino es muy ilustrativo, pues ejemplifica una tipología muy diversificada de sistemas de drenaje realizados con ánforas, de dimensiones diversas y adaptadas, evidentemente, a las circunstancias de la obra de infraestructura proyectada. De ahí que el paralelismo con las estructuras gaditanas sea notable, a pesar de no ser exactamente iguales.

En Aquileia contamos con el relleno de un canal de drenaje en la zona de Bacchina, en el agger de la colonia, compuesto por un conjunto de 5 filas horizontales de más de una decena de ejemplares cada una (Scotti 1998: 110). También se conocen ejemplos intraurbanos del s. I d.C. (Lamboglia 2, Dr. 1 y 6 A), bajo los cardines y decumani, destinados a reforzar tramos de calle que cedían (Scotti 1998: 107 y 110).

En Venecia contamos con los ejemplos de Concordia Sagittaria. Un muelle ligneo y diversos canales intramuros y extramuros, como por ejemplo un drenaje bajo una vía compuesto por ánforas horizontales sobre una empalizada de madera (Da Villa y Sandrini 1998: 115 y 120). 
Otro ejemplo muy cercano tipológicamente es el del muelle fluvial de Oderzo, antigua Opitergium (Tirelli 1987; Tirelli, Ferrarini y Cipriano 1998). Se trata de una estructura de la primera mitad del s. I d.C. de la cual se conserva parte del muelle fluvial compuesta por un ángulo realizado en quadratum con restos de su empalizada de cimentación ( $15 \times 7,4 \mathrm{~m}$ ), en cuyo interior se localizan estructuras lígneas creando paneles hidraúlicos (Tirelli, Ferrarini y Cipriano 1998: 143).

En Padua son más de cincuenta los paralelos documentados, que se centran entre mediados del s. I a.C. y el s. I d.C., caracterizándose por su diversidad, su cercanía a los ejes viarios y su concentración cerca del curso fluvial mayor (Pessavento y Ruta 1998). Se presentan ejemplos en Via Gattamelata, Via Beato Pellegrino, Roncaglia di Ponte San Nicolo y Via Giustiniani, de diversa morfología y entidad, alternando con ellas los canales (Cipriano, Mazzochin y Pastore 1998; De Vanna 1998; Moneti y Stocco 1998). Otros ejemplos se localizan en Verona, normalmente de mediados del s. I d.C., en este caso siempre en ámbito rural asociados a drenajes relacionados con las vías, y para subir el nivel de la orilla del río o para regularizar/medir la amplitud del alveo fluvial (Manasse 1998).

Especialmente útil es el trabajo realizado sobre la problemática de los denominados "argini-strade" (“diques-calles"), propios de la laguna de Venecia especialmente (Fozzatti y Toniolo 1998). Los autores plantean tres tipos de soluciones, amparadas en 29 paralelos, que remiten bien a diques-calles ("argine-strade") o a diques-saneamiento ("argine-bonifiche"), que debieron generar un paisaje característico de la laguna veneciana en la Antigüedad:

- Estructura lígnea de contenido variado, para consolidar las orillas.

- Estructura lígnea con alineaciones anfóricas, para saneamiento.

- Estructura muraria cimentada con palos para la creación de "argini-strade", con uso de material anfórico más o menos fragmentado.

De todos los ejemplos presentados describen cuatro del s. I d.C. que les permiten ilustrar las principales tipologías advertidas, todos ellos localizados en la zona septentrional de la laguna norte de Venezia, y que reproducimos en la figura 8. Se trata de Canale dell'Arco, Canale S. Felice, Canale Catene y Canale delle Vignole. Como se advierte en la figura 8, los tres primeros presentan una pavimentación de guijarros encima, constituyendo un paralelo evidente a la estructura del Caño de Sancti Petri; y los dos primeros cuentan con compactaciones superiores de material fragmentario (Fozzatti y Toniolo 1998: 201-206). Se trata en todas las ocasiones de vías elevadas destinadas al tránsito y quizás al remolque, al tiempo que permitirían la conexión endolagunar con las vías terrestres (Fozzatti y Toniolo 1998: 206). Constituyen el ejemplo más claro a nuestra estructura, que posiblemente debamos relacionar con un refuerzo de la orilla del caño, pero cuya utilidad superior está fuera de toda duda, para desarrollar funciones comerciales.

En el centro y sur de Italia son muy reducidos los ejemplos conocidos. Un buen paralelo tipológico es el de S. Anastasia, localidad situada a lo largo de la costa itálica al sur de Terracina, lugar en el cual se documentaron aparentemente un centenar de hileras horizontales de Dr. 1, cada una con tres alineaciones, en una superficie de unos $7000 \mathrm{~m}^{2}$, habiendo calculado el empleo de unos 6.500 envases, todos ellos interpretados como parte de un sistema de bonificación -secado- de una gran zona (Quilici 1998: 17-18). Este ejemplo es uno de los más cercanos a nuestro caso por la horizontalidad, la anchura y la cantidad de hileras empleadas. Podemos citar asimismo el ejemplo de Vada Volaterrana, asentamiento portuario en el cual se ha dado a conocer un pequeño "vespaio", sistema de drenaje compuesto por varias ánforas africanas completas dispuestas al revés, bajo pavimentaciones de época tardía (segunda mitad del s. IV d.C.), para evitar la humedad (Pasquinucci, Menchelli y Del Río 1998: 298). No obstante es una actividad de carácter puntual que se aleja de las grandes obras de infraestructura propias de la zona noritálica. 


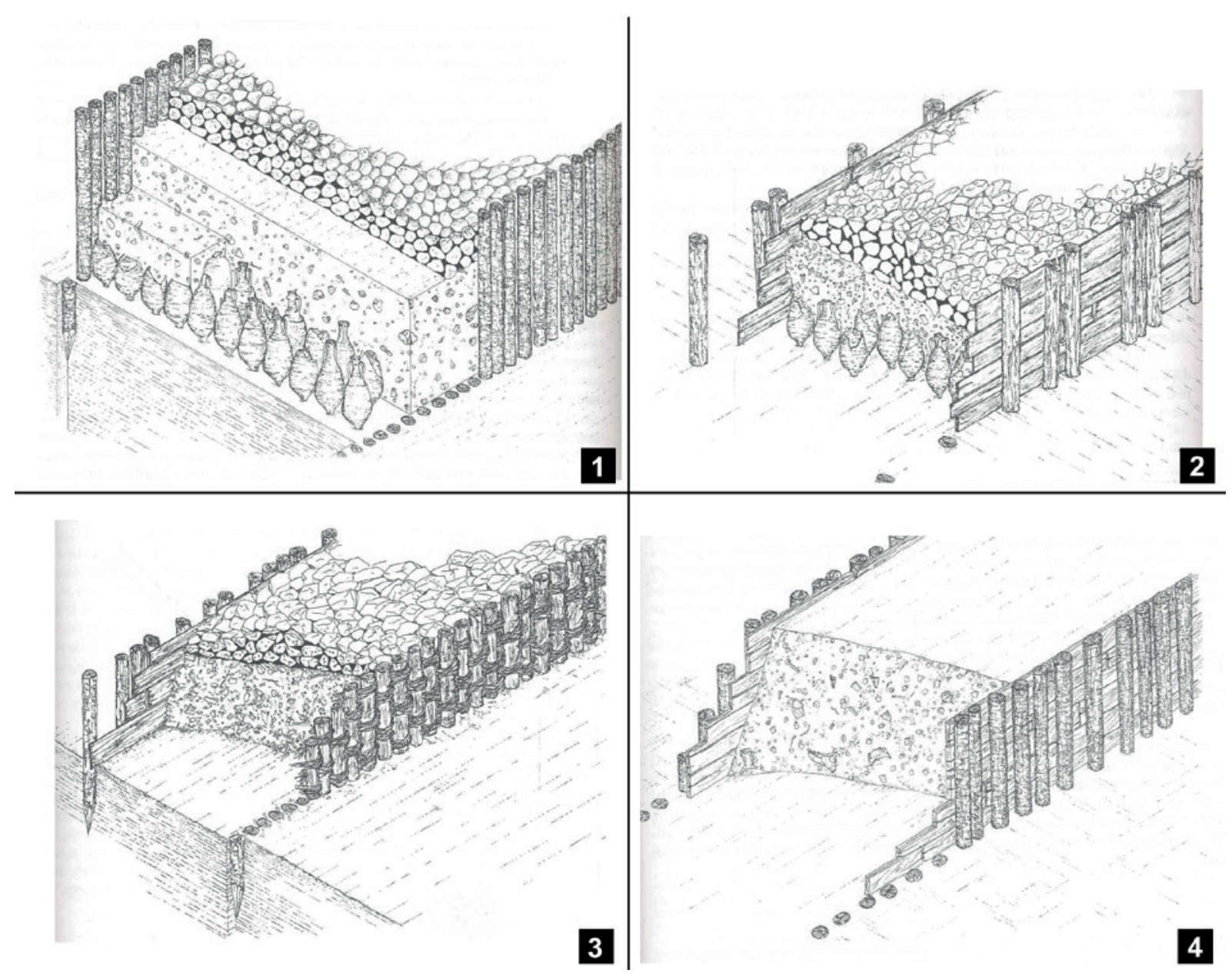

Figura 8.- Tipología de los “diques-calle” (argini-strade) de la laguna de Venecia (según Fozzati y Toniolo 1998: 201-206, figs. 1, 2, 5 y 8).

En Istria contamos con la constatación de obras de drenaje en la cimentación de un edificio en Pula, con al menos dos ejemplos bien atestiguados (Bezeczky 1998: 287). En Francia sí se conocen diversos casos destinados mayoritariamente a la protección de suelos o de unidades constructivas y al acondicionamiento de riberas, si bien los mismos no son tan voluminosos y espectaculares como los noritálicos. En primer lugar indicar que sí se detecta en esta zona una diferencia manifiesta entre época republicana y altoimperial, documentándose en primer lugar únicamente grecoitálicas y/o Dr. 1, mientras que a partir de Augusto la tipología se diversifica (Laubenheimer 1998a: 47-68). Los paralelos galos más cercanos son lo siguientes: por un lado en la "vide sanitaire" augustea de la Rue Childebert de Lyon, en la cual se detectaron 39 ánforas en disposición horizontal, o el caso de la Place Bellecour en la misma localidad, con envases horizontales alineados, machihembrados y ajustados a tres tipos básicamente en un contexto de la segunda mitad del s. I d.C. (Laubenheimer 1998a: 55 y 57). En la última zona lionesa citada se excavó entre 1984-1985 un paralelo funcional al nuestro compuesto por 178 ánforas completas en lineas yuxtapuestas, sin estructuras asociadas, interpretadas como el sistema de refuerzo de una zona pantanosa (Laubenheimer 1998a: 57-58; Burnouf y Laubenheimer e.p.). Se citan más ejemplos galos como en St. Colombe de la segunda mitad del s. I d.C., o las dos hileras horizontales de Haltern 70 embutidas unas en otras, relacionadas 
con el sistema de drenaje de una calle en Aux Aiguières (Fréjus) en los primeros decenios de la Era (Laubenheimer 1998a: 59-60, 63). Al este de Narbona se conoce la estructura de drenaje de una calle con ánforas en disposición horizontal y a veces machihembradas, de época augustea (Laubenheimer 1998a: 67).

Por último, mencionar en España la referencia al hallazgo de una estructura de drenaje junto a los ríos Huerva y Ebro, en la cual los envases se encontraban boca abajo, posiblemente destinada adicionalmente al refuerzo del cauce fluvial (Beltrán 1969; Beltrán 1970: 359 y 582; Beltrán 1985: 90)7. Posiblemente contemos con más casos en territorio peninsular, si bien las alusiones a los mismos no son habituales en la bibliografía de referencia, por lo que posiblemente en el futuro cercano se ampliará la nómina de yacimientos españoles con estas características.

En la figura 7 presentamos un mapa de distribución de las citadas estructuras drenantes que utilizan ánforas en su ejecución, hecho que permite definir dos zonas como las más importantes: la región veneto-padana y la desembocadura del Ródano.

La interpretación que se desprende de los paralelos hallados es que la estructura realizada con ánforas documentada en Los Cargaderos, a la orilla del Caño de Sancti Petri, tiene una finalidad relacionada claramente con la evacuación de agua (drenaje). Además, por su localización junto al curso del caño de Sancti Petri pensamos que posiblemente fue también utilizada para reforzar una de las márgenes de dicha vía acuática, como ya hemos visto en otros ejemplos italianos y franceses. Posiblemente en este caso sería un modelo mixto, pues serviría tanto para la evacuación de las aguas pluviales como para evitar la subida de la misma por capilaridad. Su tipología sí es excepcional en la Hispania meridional ante la ausencia de paralelos, si bien se trata de una obra de ingeniería que remite a modelos bien conocidos en otros lugares del Mediterráneo, como hemos tenido ocasión de comprobar en los párrafos precedentes.

\subsection{3.- Estructuras destinadas al tránsito: pavimentos y regularizaciones.}

En relación a las estructuras del Caño de Sancti Petri debemos destacar un último aspecto funcional, como es la existencia de una plataforma horizontal sobre las estructuras de drenaje, en nuestro caso constituida por un pavimento realizado con cantos y gravas.

En el puerto de Caesaraugusta, erigido en época augusteo-tiberiana, el modelo se basa en la existencia de una zona superior dotada de construcciones públicas monumentales, a cuyos pies existiría una calle de $20 \mathrm{~m}$ de anchura que daba paso a una terraza inferior mediante un sistema de rampas, en la cual se ubicaría una plataforma prácticamente a nivel del río, sobre la cual apoyarían los pantalanes de madera perpendiculares a la orilla, citando como paralelos Aquileia y Fiumicino (Aguarod y Erice 2003:146-149). Evidentemente los paralelismos con las estructuras gaditanas derivan de la terraza inferior a la cual se adosarían los muelles lígneos, y en la cual se podrían realizar actividades de carga y descarga, facilitar la circulación y el apeo de las grúas portuarias (Aguarod y Erice 2003: 149).

Tenemos un ejemplo en el área portuaria fluvial excavada en Valentia, en la cual se detectaron una serie de obras de acondicionamiento de la superficie, entre las que se citan actividades de compactación y la existencia de al menos una pavimentación realizada con cantos rodados (Burriel, Ribera y Serrano 2003: 134-135).

En el área noritálica, contamos con algunos ejemplos similares, como es el caso de una estructura de drenaje de Altino realizada con ánforas en disposición horizontal, que sirvió de cimentación para

7. Agradecemos al Dr. J. Liz Guiral, de la Universidad de Salamanca, su gentileza al proporcionarnos estos datos. 
una compactación superior realizada con tierra y fragmentos cerámicos (Tirelli y Toniolo 1998: 91). Es decir, cimentaciones de superestructuras, como el caso gaditano aquí tratado. También el ejemplo veneciano citado (Concordia Sagittaria) presenta una regularización superior similar, mediante un nivel de apisonamiento compuesto por fragmentos pétreos, latericios y anfóricos, a modo de pavimento ( $\mathrm{Da}$ Villa y Sandrini 1998: 127). En Cremona contamos con el gran sistema de drenaje de mediados del s. I d.C. documentado en vía Massarotti, compuesto por multitud de envases colmatando el interior de una gran fosa excavada en el geológico (Pitcher 1998: 132). Destacamos la localización sobre su parte superior de un estrecho camino construido con sesquipedales, sendero que conducía hacia el curso del río Po (Pitcher 1998: 132), y que confirma que la parte superior de esta estructura también era transitable. Un ejemplo análogo también en Cremona es la estructura sobre el drenaje compuesto por varias hileras de ánforas, sobre la cual se construyó asimismo una pasarela de ladrillos sesquipedales, a finales del s. I d.C. (Mariotti 1998: 291-292). Recordamos también ahora el citado muelle fluvial de Oderzo, sobre el cual se propone la existencia de un horreum con finalidad comercial (Tirelli, Ferrarini y Cipriano 1998: 143). Por último, citar los ejemplos comentados anteriormente de "argini-strade" en la laguna de Venecia, la mayor parte de los cuales aparecen pavimentados en su parte superior, en un modo prácticamente idéntico al de nuestra estructura (Fozzatti y Toniolo 1998: 201-206). Estos últimos constituyen los paralelos más cercanos a la estructura excavada en la orilla del Caño de Sancti Petri.

De los paralelos citados se deduce que en algunas ocasiones se trata de sistemas de saneamiento y drenaje destinados a crear zonas superiores de tránsito, pavimentadas o no. Esta es la situación localizada en Los Cargaderos, caracterizada por la existencia de una pavimentación que confirma que la interfaz superior de la estructura estaba destinada al tránsito continuado. También sobre ellas a veces se constata la instalación de estructuras aéreas (habitaciones, pequeños horrea portuarios...). En nuestro yacimiento gaditano pocos restos han aparecido, si bien debemos pensar en algún tipo de instalación para facilitar el trabajo de los mercatores.

\subsection{4.- Estructuras con ánforas en San Fernando.}

Presentamos a continuación un sucinto listado de las estructuras realizadas con ánforas documentadas en la isla de San Fernando, para ilustrar la importancia de este tipo de edificaciones en el archipiélago gaditano, aspecto éste sobre el que recientemente llamamos la atención (Bernal et alii 2003: 216). Normalmente se trata de canalizaciones $\left(\mathrm{n}^{\circ} 1,2,3, i 4 ?, i 5 ?, 6,7\right)$, mientras que en otras ocasiones su funcionalidad no es clara, vinculándose a la compartimentación de espacios, siendo muy abundante su presencia en ambientes alfareros (Lagóstena y Bernal 2004: 103).

\begin{tabular}{|c|c|c|c|c|c|}
\hline $\mathrm{N}^{\mathrm{o}}$ & Yacimiento & Funcionalidad & Tipo ánforas & Cronología & Bibliografía \\
\hline 1 & C/ Asteroides & Canalización & T-7.4.3.3 & s. I a.C. & Bernal et alii e.p. \\
\hline 2 & Parque Natural & Canalización & Beltrán II & s. I d.C. & $\begin{array}{c}\text { Bernal } \text { et alii 2003: } \\
22-23 .\end{array}$ \\
\hline 3 & $\begin{array}{c}\text { Parque Natural (PK } \\
370)\end{array}$ & Canalización & Dr. 7/11 y tubuli & $\begin{array}{c}\text { Fines s. I a.C. o } \\
\text { principios I d.C. }\end{array}$ & $\begin{array}{c}\text { Bernal } \text { et alii 2003: } \\
107-112 .\end{array}$ \\
\hline 4 & $\begin{array}{c}\text { Parque Natural (PK } \\
473)\end{array}$ & ¿Canalización? & $\begin{array}{c}\text { Dr. 7/11 y Beltrán } \\
\text { IIA }\end{array}$ & s. I d.C. & $\begin{array}{c}\text { Bernal } \text { et alii 2003: } \\
113-116 .\end{array}$ \\
\hline 5 & $\begin{array}{c}\text { La Milagrosa } \\
\text { (PK 833-840) }\end{array}$ & ¿Canalización? & $\begin{array}{c}\text { T-7.4.3.3, Dr. 1C, } \\
\text { Dr. 7/11 }\end{array}$ & $\begin{array}{c}\text { Segunda mitad s. I } \\
\text { a.C. }\end{array}$ & $\begin{array}{c}\text { Bernal } \text { et alii 2003: } \\
182-187 .\end{array}$ \\
\hline
\end{tabular}




\begin{tabular}{|c|c|c|c|c|c|}
\hline $\mathrm{N}^{\mathbf{2}}$ & Yacimiento & Funcionalidad & Tipo ánforas & Cronología & Bibliografía \\
\hline 6 & $\begin{array}{c}\text { La Milagrosa } \\
\text { (PK 994) }\end{array}$ & Canalización & T-7.4.3.3 & $\begin{array}{c}\text { Fines s. II o } \\
\text { principios s. I a.C. }\end{array}$ & $\begin{array}{c}\text { Bernal et alii 2003: } \\
205-208 .\end{array}$ \\
\hline 7 & $\begin{array}{c}\text { Marismas del Río } \\
\text { Arillo }\end{array}$ & Canalización & Dr. 7/11 & Altoimperial & Arteaga y Roos, e.p. \\
\hline 8 & $\begin{array}{c}\text { Villa de Avda. } \\
\text { Consitución }\end{array}$ & Indeterminada & Dr. 1C y Dr. 7/11 & $\begin{array}{c}\text { Fines s. I a.C. o } \\
\text { principios I d.C. }\end{array}$ & Pineda 2001 \\
\hline 9 & $\begin{array}{c}\text { Gallineras } \\
10\end{array}$ & $\begin{array}{c}\text { Indeterminada } \\
\text { Mártires }\end{array}$ & Dr. 1C y Dr. 7/11 & $\begin{array}{c}\text { Fines s. I a.C. o } \\
\text { principios I d.C. }\end{array}$ & Sáez et alii 2003 \\
\hline
\end{tabular}

Otros hallazgos en la Bahía de Cádiz confirman la importancia de este tipo de estructuras en todo el ámbito del archipiélago, y en general en zonas fluvio-marítimas. En la ciudad de Cádiz contamos con recientes hallazgos tales como los de la c/ Chile o los Cuarteles de Varela, todos ellos inéditos. En Puerto Real baste mencionar las espectaculares estructuras del taller de Villanueva, realizadas con Dr. 7/11 creando varios espacios de al menos dos alturas (Lagóstena y Bernal 2004). Y en el entorno de la Base Naval de Rota la estructura con Dr. 7/11 y ¿Haltern 70? fechada en el s. I d.C. (López y Pérez 1980). Son únicamente algunos ejemplos que confirman la importancia de esta línea de trabajo para el futuro, y de la existencia de multitud de alineaciones de ánforas reutilizadas con finalidad constructiva o, en general, para la delimitación de ámbitos espaciales.

\section{LAS ÁNFORAS REUTILIZADAS EN LA ESTRUCTURA DE LOS CARGADEROS}

El estado de conservación de las ánforas recuperadas en la excavación era muy deficiente en la mayor parte de las ocasiones, al haber soportado las mismas notables presiones, que provocaron su ruptura y notable fragmentación, fenómeno especialmente acusado en el Nivel Superior, al encontrarse el mismo prácticamente en superficie (figura $3 \mathrm{~A}$ ). De ahí que únicamente contemos con 8 perfiles completos o reconstruibles $\left(n^{\circ} 1-5,29-31\right)$ de los 34 individuos recuperados, de los que ilustramos en este trabajo una selección de los ejemplares mejor conservados (figuras 9 a 12). Debemos pensar que corresponden únicamente a la mitad aproximadamente de la cantidad de ejemplares que teóricamente pudo haber albergado la zona excavada (en torno a 60), teniendo en cuenta un conjunto de 6 ánforas por hilera (Cfr. la Alineación 5, compuesta en la zona intervenida por 5 ánforas, de las que falta una al norte) en un conjunto de 10 alineaciones (figura 6).

La variedad de envases reutilizados, que ascienden a 6 tipos diferentes, no parece indicar un proceso de selección intencional de ánforas guiado por su morfología, como sí sucede en el caso de algunas "vides sanitaires" francesas en las cuales la recurrencia a Dr. 20 es constante (Laubenheimer 1998a). De los ejemplos de estructuras drenantes con ánforas recogidos en el apartado precedente, parece que en la Península Itálica normalmente son las ánforas de producción local/regional las más abundantes, mientras que en Francia predominan los ejemplares importados en época altoimperial, pues la situación republicana es claramente tendenciosa -omnipresencia de grecoitálicas y Dr. 1- (Pessavento 1998). En Los Cargaderos en la Bahía de Cádiz, la frecuencia de ánforas importadas asciende al 25\% circa (Cfr. Tabla infra), por lo que se encontraría más cerca del entorno de la desembocadura del Ródano. 
En Los Cargaderos parece que no se procedió a la selección de envases por su robustez y resistencia, tendentes a garantizar la solidez de la estructura. Por el contrario, da la impresión que se reutilizó un lote completo de ánforas desechadas, posiblemente tras el trasvase de los contenidos a otros envases, habiendo acopiado las ánforas ya inútiles, reutilizándolas con fines edilicios. Así parecen indicarlo las evidencias de que algunas de ellas sí fueron utilizadas, hecho evidente en los ejemplares completos (especialmente una de las Dr. 7/11 - $\mathrm{n}^{\circ} 2-$ y la Dr. 2/4 tarraconense $-\mathrm{n}^{\circ} 29-$, que contaban con residuos al interior ${ }^{8}$ ) y atestiguado asimismo en las salsarias locales (Dr. 7/11 y Beltrán II A y B) por la presencia de adherencias de resina en la pared interior de casi una cuarta parte de las mismas $\left(\mathrm{n}^{\circ} 1,5,10,11\right.$, 13,19 y 22). Por ello consideramos a todas las piezas como contenedores de mercancías de transporte (debemos destacar la ausencia de ánforas salsarias locales con defectos de cocción que indicasen su procedencia de una de las cercanas figlinae). De ahí que al final utilicemos este depósito para plantear algunas inferencias sobre el comercio en la Bahía de Cádiz en época altoimperial, por cuanto consideramos este contexto cerámico como ilustrativo de la dinámica comercial de la zona, al no haber sido objeto, aparentemente, de proceso de selección alguno.

A continuación incluimos la adscripción tipológica de todas las piezas en una tabla, guiados por la zona de manufactura y los contenidos.

\section{TiPOLOGÍA DE LAS ÁNFORAS DE LOS CARGADEROS}

\begin{tabular}{|c|c|c|c|c|c|}
\hline Zona de manufactura & Tipología & $\mathrm{N}^{\mathrm{o}}$ Catálogo & \multicolumn{2}{|c|}{ Contenido } & \multicolumn{2}{|c|}{ Porcentaje } \\
\hline \multirow{3}{*}{ Bahía de Cádiz } & Dr. $7 / 11$ & $1,2,5,23,24$ & & 14,7 & \multirow{2}{*}{$73,5 \%$} \\
\cline { 2 - 3 } & Beltrán II A & $4,6,7,8,10-13,15-22,34$ & \multirow{2}{*}{ Salazones } & 50 & \\
\cline { 2 - 3 } & Beltran II B & $3,9(?), 14$ & & 8,8 & \\
\hline Valle del Guadalquivir/Genil & Dr. 20 & $25-28$ & Aceite & $11,5 \%$ \\
\hline Lusitania & Dr. 14 & 30,31 & Salazones & $6 \%$ \\
\hline Tarraconense costera & Dr. $2 / 4$ & 29 & Vino & $3 \%$ \\
\hline Península itálica & Dr. $2 / 4$ & 32,33 & Vino & $6 \%$ \\
\hline
\end{tabular}

El conjunto más numeroso es el compuesto por las ánforas salsarias de producción gaditana, pues todas ellas presentan las típicas pastas amarillentas propias de los alfares de la bahía, aspectos éstos confirmados por el estudio arqueométrico realizado (Bernal et alii 2004b). Se ha documentado una trilogía tipológica muy útil a efectos cronológicos, pues documentamos algunas de las producciones más tardías de la familia de las Dr. 7/11 conjuntamente con una predominancia clara de las Beltrán II A y con las primeras series de Beltrán II B.

Del primer grupo contamos con dos ejemplares completos ( $\mathrm{n}^{\mathrm{o}} 1$ y 2 ) y un tercero al cual únicamente le falta la boca $\left(\mathrm{n}^{\circ} 5\right)$ y dos asas fragmentadas $\left(\mathrm{n}^{\circ} 23\right.$ y 24), la primera de ellas con una tenue acanaladura dorsal. Las dos piezas completas se ajustan a los prototipos tipológicos de la variante más tardía de las Dr. 7, caracterizada por presentar unos bordes exvasados y apuntados -más cercanos a la Beltrán II A que a las Dr. 7/11-, un largo cuello cilíndrico, asas de cinta de trayectoria vertical muy acodadas en su extremo superior, panza piriforme y pivote hueco de tendencia

8. Algunas ánforas, entre ellas una de las Dr. 14 lusitanas, presentaba adherencias negruzcas resultado de los restos del contenido de otro ejemplar ( $\mathrm{n}^{\mathrm{o}} 2$ 2?), que habían impregnado su pared. Asimismo, al flotar el sedimento fangoso entre las ánforas, aparecieron algunos restos de pepitas de uva. Estos detalles parecen indicar que los envases fueron reutilizados en la construcción inmediatamente tras su vaciado, lo que habría provocado que las adherencias de la pared hubiesen rezumado, al encontrarse aún en estado semi-líquido. 
troncocónica invertida (figura $9, \mathrm{n}^{\mathrm{o}} 1$ y 2 ). Esta variante se documenta desde época claudia hasta finales del s. I d.C., con dataciones contrastadas en época neroniana, vespasianea -Ses Salines-y durante el último cuarto del s. I d.C. en Vindonissa (problemática general en García Vargas 1998: 82). Ya desde época de Claudio está plenamente consolidada la forma, como se desprende de los ejemplares documentados en el pecio corso de La Tour Ste. Marie, muy similares cercanos tipológicamente a las ánforas de Los Cargaderos (Laubenheimer 1998b: 320-322, fig. 3, "type 6"). En la Bahía de Cádiz su producción está atestiguada al menos en El Olivar de los Valencianos y especialmente en la denominada Fase II del taller de Puente Melchor (García Vargas 1998: 82, fig. 47.1 y 53.1-2), ejemplares éstos últimos con los que presenta mucha más afinidad tipológica. No olvidemos que la denominada Fase II de Puente Melchor se fecha en época claudio-neroniana y en los primeros momentos de la dinastía flavia (García Vargas 1998: 184). Respecto al tercer ejemplar $\left(n^{\circ} 5\right)$, su cuello menos cilíndrico, de tendencia hiperbólica, el aspecto más ovoide de su panza, la mayor sinuosidad de sus asas -que además están claramente acanaladas dorsalmente frente a la sobriedad de los ejemplares anteriores- y su pivote, más corto, de tendencia troncocónica más acusada y con las paredes más gruesas, induce a emparentar la pieza con las Dr. 8 de Villanueva, que se fechan en el tercer cuarto del s. I d.C. (García Vargas 1998: 179, fig. 48, 1-4 y 49, 1-2), si bien la ausencia de borde no permite una filiación clara. Esta pieza presenta un grafito en el pivote, en forma de $\mathrm{S}$ sinuosa (figura $9, \mathrm{n}^{\circ}$ 5), marca de control productivo asociada a la actividad interna de las figlinae bien documentada en las alfarerías gaditanas, especialmente en Puerto Real (Pérez, Alonso y Núñez 1999: 706, fig. 2, nº 36 y 37).

Efectivamente, resulta singular la coincidencia tipológica de las producciones anfóricas asociadas a la Fase II del taller de Puente Melchor con la mayor parte de ánforas salsarias documentadas en Los Cargaderos. En este taller puertorealense se manufacturaban en su denominada Fase II (segunda mitad del s. I d.C.) tanto Dr. 7 D, Dr. 8, 9, 10, 12, 17, Haltern 70, Beltrán II A C, Beltrán II B A y Dr. 20 (García Vargas 1998: 181), es decir un contexto anfórico muy similar al documentado en el yacimiento que presentamos (Dr. 7 tardías, Beltrán II A y B y Dr. 20). Esta misma tendencia ha sido señalada para el caso del taller de Villanueva, datado en el tercer cuarto del s. I d.C. (García Vargas 1998: 84), en el cual las asociaciones de Dr. 8 con formas evolucionadas de la Dr. 11 y con Beltrán II A y Beltrán II B antiguas plantea notables similitudes con las dataciones flavias de Pompeya (Manacorda 1977: 123) y del depósito lionés de Bas-de-Loyasse (Dangreaux y Desbat 1987-88).

Debemos destacar el hallazgo de residuos del contenido asociados a una de estas ánforas salsarias $\left(\mathrm{n}^{\mathrm{o}} 2\right)$, consistentes en restos de "nodulos grasientos" y escamas de pescado. Se procedió al análisis de dichos restos, habiendo podido determinar en el caso de los nódulos un contenido en grasas y aceites del 4,25\% -mediante gravimetría, previa extracción con Soxhlet con hexano como disolvente-, y por cromatografía gaseosa la composición del extracto aceitoso de dichas muestras, la cual indicaba un alto contenido en aceites insaturados, típicos de muestras procedentes de aceites de pescado ${ }^{9}$. Respecto a los restos de ictiofauna, no fue posible la identificación de los posibles huesos de peces mediante lupa, debido al notable estado de fraccionamiento de la muestra ${ }^{10}$. De todo ello se deduce que el contenido de este envase era un producto salsario de origen marino, más que trozos de carne en salazón.

Por su parte, en la tabla de frecuencias se advierte cómo la forma más abundante en este contexto gaditano es la Beltrán II A, con 17 ejemplares ( $\left.n^{\circ} 4,6,7,8,10-13,15-22,34\right)$. Todos ellos se ajustan a diversas variantes tipológicas, si bien la tendencia general es presentar bordes de sección triangular

9. Según Informe inédito realizado por el Dr. L.I. Romero García, Profesor Titular de Ingeniería Química de la Universidad de Cádiz, fechado el 10 de diciembre de 1996 (Archivo del MHMSF).

10. Según Informe inédito realizado por el Dr. J.M. Cantoral, de la Universidad de Cádiz, fechado en junio de 1996 (Archivo del MHMSF).

ISSN: 1133-4525 ISSN-e: 2255-3924

SPAL 14 (2005)

http://dx.doi.org/10.12795/spal.2005.i14.07 
muy apuntada $\left(\mathrm{n}^{\mathrm{o}} 4,6,7,8,10-13,15-20\right.$ y 34$)$, propios de un momento plenamente consolidado de esta forma, relacionados en su totalidad con las denominadas variantes "A o de borde apuntado" del taller de la Venta del Carmen que se data entre época augustea avanzada y momentos tardoflavios, no siendo posible por el momento mayores precisiones al respecto (Bernal 1998: 146, fig. 109 y 158). Paradójicamente, a pesar de que esta forma es una de las más frecuentes en contextos productivos gaditanos del s. I avanzado e inicios del s. II d.C. (Lagóstena y Bernal 2004: 107), su seriación tipocronológica aún está necesitada de estudios de precisión al respecto. Su cronología general en la Bahía de Cádiz se sitúa aparentemente entre época de Tiberio y mediados del s. II d.C. Recordar únicamente que los ejemplares de Los Cargaderos presentan individuos tanto con elementos que tradicionalmente se consideran "arcaismos" en la evolución tipológica de la forma, sobre todo las carenaciones en la parte baja del borde $\left(n^{\circ} 4,7\right.$ y 13$)$ y del cuello $\left(n^{\circ} 6,8\right.$ y 13$)$ y el gran espacio existente entre el plano inferior del borde y el superior del asa $\left(n^{\circ} 4,7,10\right.$ y 11), frente a otros indicios de mayor modernidad evolutiva tales como la carencia de espacio entre el borde y el arranque de asa $\left(n^{\circ} 6\right.$ y 8$)$ o la total ausencia de carenas en el tercio superior $\left(n^{\circ} 4,7,11,12,19\right.$ y 34). Es decir, una coincidencia de detalles que no permiten precisar al respecto, si bien parece que nos encontramos ante ejemplares no muy precoces ni muy evolucionados (especialmente por la estilización del borde ya mencionada), por lo que genéricamente responden a los modelos habituales en la segunda mitad del s. I d.C. y momentos iniciales del s. II d.C. En uno de los pivotes macizos y huecos de Beltrán II $\mathrm{A}\left(\mathrm{n}^{\circ} 21\right)$ se documenta un grafito anepígrafo constituido por un trazo oblicuo al que se le cruzan dos en su parte inferior, marca parecida a las de algunos talleres de Puerto Real (Pérez, Alonso y Núñez 1999: $n^{\circ} 20,99$ y 107).

Por último en el caso de las producciones salsero-salazoneras gaditanas, debemos mencionar la documentación de al menos tres Beltrán II B tempranas ( $n^{\circ} 3,9$ y 14), caracterizadas por bordes muy desarrollados, ampliamente separados del plano superior del asa y con una moldura marcada de transición entre el borde y el cuello $\left(n^{\circ} 3\right)$. En el caso del ejemplar completo, sus analogías con la Beltrán II A son notables, de la cual se diferencia casi únicamente en el borde, muy exvasado y de tendencia apuntada. Estas Beltrán II B precoces -variante B A de García- se suelen datar como pronto en época de Claudio, si bien su atestación es especialmente abundante a partir de momentos flavios, variante que perdura únicamente hasta finales del s. I d.C. según, una vez más, la estratigrafía de Puente Melchor -Fase II- (García Vargas 1998: 109-110).

Las ánforas de importación aparecen representadas en Los Cargaderos por tres grupos. Olearias del valle del Guadalquivir/Genil (Dr. 20), ánforas salsarias/salazoneras lusitanas (Dr. 14) y vinarias tarraconenses e itálicas (Dr. 2/4).

Respecto a las Dr. 20, todas ellas pertenecen a individuos diferentes, y presentan en su totalidad pastas del Valle del Guadalquivir/Genil, por lo que constituyen productos importados. Tipológicamente debemos destacar del único tercio superior conservado (figura 10, $n^{\circ} 25$ ) la gran molduración interior del borde y el acusado estilizamiento del cuello, aspectos ambos que cuadran con el estadío flavio-trajaneo de la evolución de esta forma (Berni 1998: 38-42, fig. 9). La única marca documentada se localiza en la parte dorsal del asa, en cartela rectangular y con las letras en relieve (fig. 10, $\mathrm{n}^{\circ}$ 27). La impresión de la marca es deficiente, dejando entrever únicamente la mitad superior de los caracteres, si bien su restitución como M.A.R. no plantea dudas. Se trata de una marca muy bien atestiguada en centros de producción béticos, documentándose una variante sin interpunciones en Las Delicias (Écija) en conexión con CEM o PS.AVITI, y con dataciones centradas entre el 30-70 en Augst, en los Castra Praetoria de Roma-CIL XV, 3020-, o en Avenches entre época de Domiciano y Trajano; aunque también se asocia al alfar de La Rambla y Acebuchal (Chic 2001: 82, 84, 85 y 164-165). La marca con interpunciones, que esconde tras de sí unos tria nomina, y que es la que más nos interesa, se asocia también al conocido centro productor de La Catria (Lora del Río), 


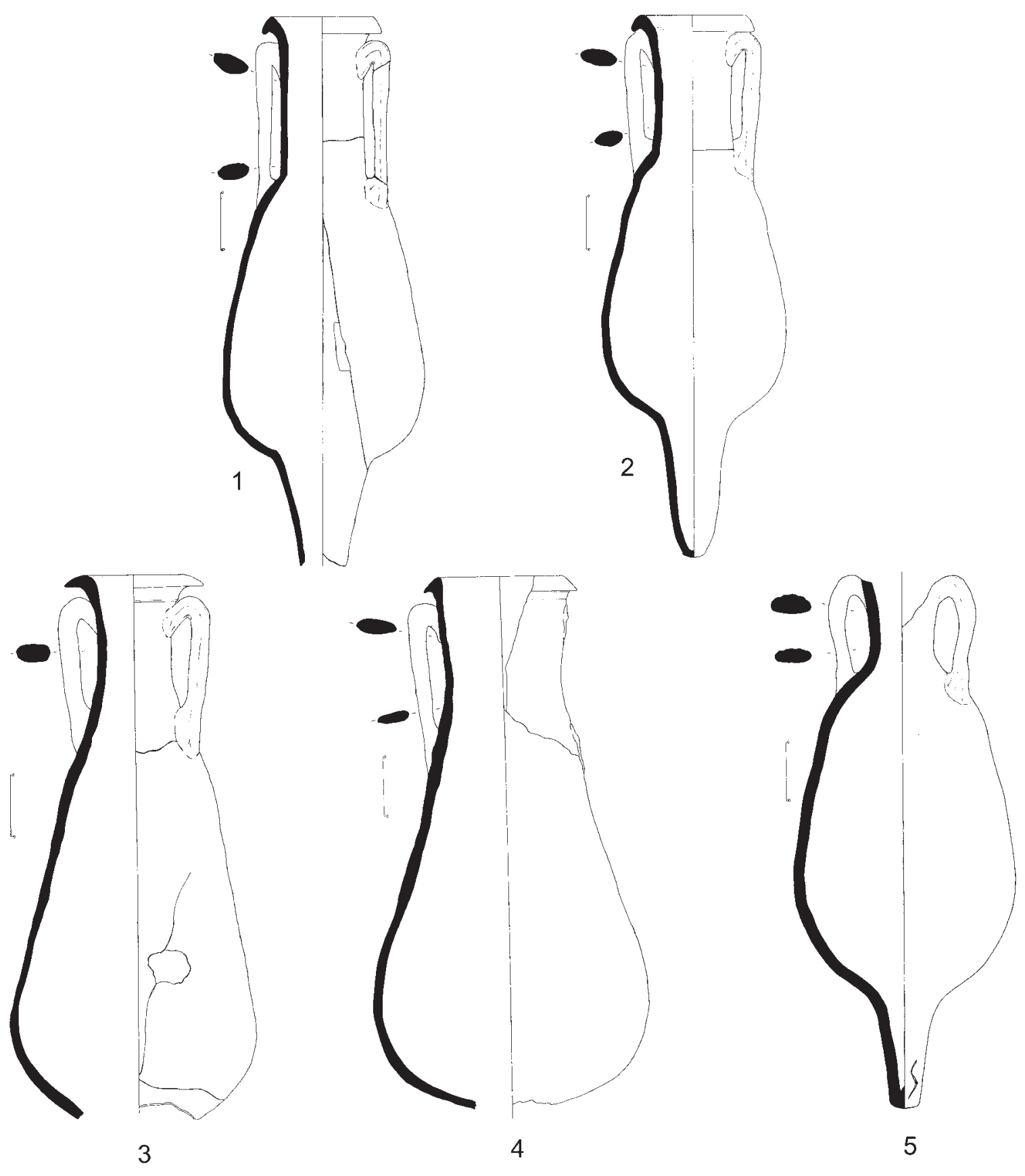

Figura 9.- Ánforas salsarias de producción local completas (1, 2.- Dr. 7 D/Beltrán II A; 3.- Beltrán II B; 4.- Beltrán II A; 5.- Dr. 7/11).

citando también su presencia en el Hospital de las Cinco Llagas de Sevilla, con más de una decena de paralelos por todo el imperio, de los cuales se precisa la datación del de Augst-s. I d.C., Pompeya y Southwark -120/200- (Chic 2001: 176, 185-186 y 284). Se conoce la misma marca en la figlina de Azanaque-Castillejo, habiéndose propuesto su desarrollo como M. Annius Rufinus o M. Aemilius 

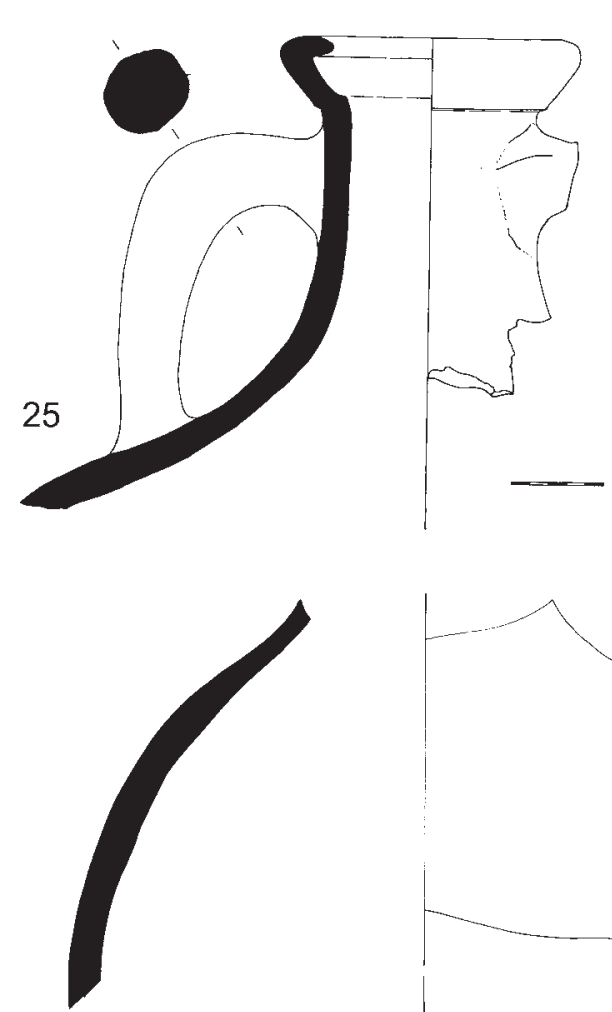

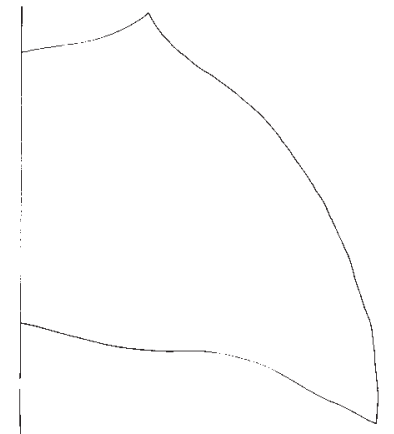

26
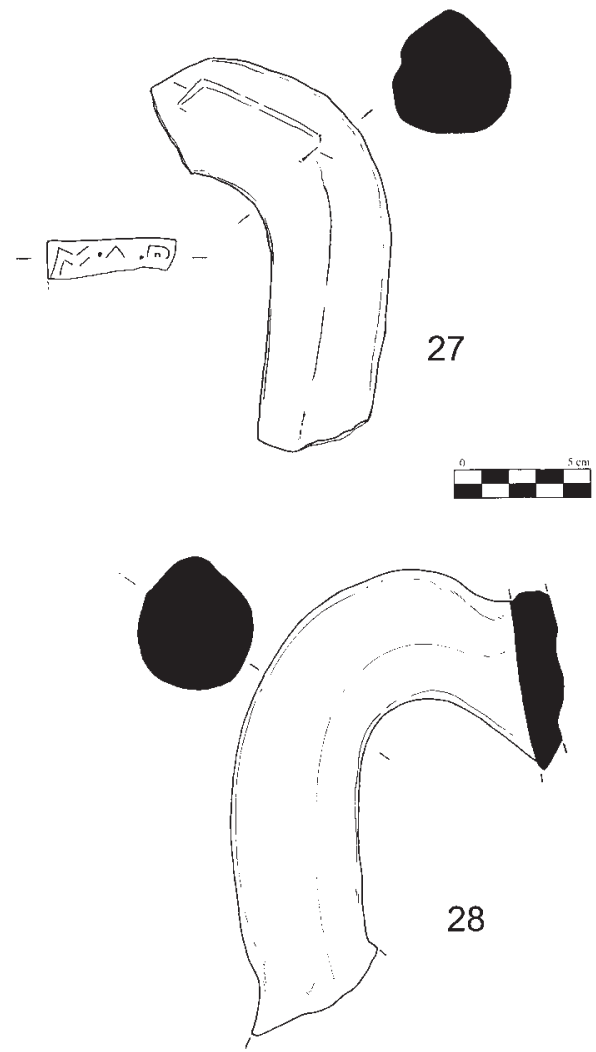

Figura 10.- Olearias del valle del Guadalquivir (25-28.- Dr. 20).

Rusticus, onomástica conocida en la epigrafía anfórica bética que se suele fechar entre el 80 y 130 -Callender-, el 90-190 d.C. -Martin Kilcher-, época augustea/flavia -Remesal- y época flavia/ mediados s. II -Mayet- (Chic 2001: 217, 232). La datación que tradicionalmente se plantea para la marca M.A.R. oscila entre época flavio-trajanea, trajaneo-adrianea, 10-70 en Augst o antes del 50 en Londinium (Cfr. las diferentes propuestas en Carreras y Funari 1998, 96). La consulta realizada en la Base de Datos del Ceipac de la Universidad de Barcelona ${ }^{11}$ (www.ub.es/CEIPAC/ceipac.html) ha permitido constatar en febrero de 2005 un conjunto de 43 atestaciones de esta marca asociadas a Dr. 20 béticas, distribuidas básicamente por la Tingitana, Tarraconense, Britannia, el limes renano-danubiano, la costa gala y Roma, de las que destacamos las fechadas entre el 120-200 en Southwark (CEIPAC $n^{\circ} 15741$ ), la ya citada de Londres anterior al 50 d.C. (CEIPAC ${ }^{\circ} 15740$ ) y la francesa de Ehl del s. I d.C. (CEIPAC n ${ }^{\circ}$ 7907).

Recientemente, las excavaciones en el alfar sevillano localizado en el antiguo Hospital de las Cinco Llagas -sede del actual Parlamento de Andalucía-, han documentado esta marca asociada a la denominada Fase I del taller, fechada en la segunda mitad del s. I d.C. (García Vargas 2001: 200 y 209), si bien resulta singular la sintonía tipológica de los bordes como el documentado en Los Cargaderos ( $\left.\mathrm{n}^{\circ} 25\right)$ con

11. Agradecemos al Dr. J. Remesal las facilidades prestadas para el acceso, consulta y uso de los datos de la misma. 
las Dr. 20 fechadas en la Fase II, que se data en el primer cuarto del s. II d.C. (García Vargas 2001: 200 y fig. 3 y 4). En nuestro caso, como ya hemos comentado, pensamos que el desarrollo tipológico de las Dr. 20 hace pensar en una cronología de época flavio-trajanea, momentos en los cuales también se puede encuadrar la marca localizada.

Por último, resulta interesante comprobar cómo en términos generales el consumo de aceite bético supera el 10\% del total de las importaciones, denotando una tendencia ya constatada en la bahía gaditana desde época julio-claudia con claridad, como han demostrado recientemente los contextos de la villa maritima de Parque Natural, en la cual las Dr. 20 tempranas se documentan desde los niveles de época tardorrepublicana-augustea (Bernal et alii 2003: fig. 18, 2; fig. 20,2) hasta el abandono del asentamiento entre los años 60 y 70 d.C., situándose inmediatamente tras las producciones salsarias locales (Bernal et alii 2003: 147-148).

En el caso de las Dr. 14 lusitanas, contamos con dos ánforas completas (figura 11, $\mathrm{n}^{\circ} 30$ y 31). Las recientes actuaciones arqueológicas realizadas en los talleres de Pinheiro (Mayet y Tavares 1998) y Abul (Mayet y Tavares 2002) han permitido precisar sobre el origen y la evolución tipocronológica de esta forma, hoy en día bien caracterizada (Fabião 2004). Nuestros dos ejemplares presentan estilizados cuellos de tendencia acampanada invertida, rematados en bordes carenados al exterior, asas verticales de sección oval con moldura externa, panza ovoide y pivote troncocónico invertido y hueco, con apéndice de botón (figura 11, nº 30 y 31 ). Estas características, la presencia aún de acanaladura dorsal en el asa y el aspecto general estilizado de la pieza, y especialmente la total ausencia de molduración exterior del borde y el acusado reflejo del "botón" terminal del pivote permiten considerar a estas Dr. 14 lusitanas como asimilables a la variante $\mathrm{C}$ definida en Abul, que es la más abundante en este taller y que parece corresponder cronológicamente a la totalidad del s. II d.C. (Mayet y Tavares 2002: 105108, figs. 65-68). Por el contrario, en Pinheiro, se relaciona más con la Dr. 14 variante B "au bord triangulaire", que se suele datar en la segunda mitad del s. I d.C., alejándose en cualquier caso de los bordes engrosados semicircularmente al exterior característicos de la variante del s. II d.C. -C- (Mayet y Tavares 1998: 63; figs. 20-21).

La comparativa macroscópica de pastas realizada (comparación visual con muestras del Porto dos Casos, Quinta do Rouxinol, Pinheiro y otros talleres de la zona del Sado), ha permitido constatar una gran similitud de estos dos envases, con pastas muy ricas en mica y desgrasantes metamórficos heterométricos, con las del taller del Porto dos Cacos, si bien algunas muestras de ánforas sadinas mostraban similitudes formales. Su autoctonía de un centro productor preciso deberá ser establecida en el futuro recurriendo a la analítica físico-química. Destacar, por último, que este es uno de los primeros ejemplos claros en la bahía gaditana con una significativa presencia de ánforas lusitanas, que se sitúan en torno al 6\% del total de las importaciones detectadas. A ellas debemos sumar el ejemplar con marca GERMANVS/GERMANVS documentado en Carteia (Bernal 1997: 362, fig. 129), procedente del Porto dos Cacos (Fabião 2004: 390).

Por otro lado, debemos destacar la documentación de tres Dr. 2/4 vinarias ( $n^{\circ} 29,32$ y 33). La primera de ellas apareció completa (figura $11, \mathrm{n}^{\circ} 29$ ), y se caracteriza por su elevada estilización, que provoca una reducida anchura del diámetro de la panza, y por presentar un borde de sección cuadrangular y las características asas geminadas, cuyo remate superior es muy acodado. Bordes similares los encontramos, por ejemplo, en el taller tarraconense de Tivissa, en momentos avanzados del s. I d.C. (Revilla 1993: 58-71, fig. 11) y en talleres como Llanfranc (Miró 1988: 81, fig. 162 y 3). Pensamos que es más probable que esta pieza proceda de talleres de la tarraconense septentrional, pues las ánforas manufacturadas en los territorios de Valentia (Aranegui y Mantilla 1987) o Dianium (Gisbert 1987) se alejan tipológicamente de nuestra ánfora, mucho más estilizada y como indicamos con el borde de sección rectangular. Son múltiples los paralelos de estos tipos, asociables como decimos a talleres del entorno de la Cataluña romana (Fariñas, Fernández y Hesnard 1977: 196, 2002-203, especialmente nº 22, 50 y 54). 
Documentamos algunos ejemplares de Dr. 2/4 tarraconenses muy cercanos tipológicos a nuestra pieza en el "Second Amphora Wall" de Cartago, en un contexto de mediados del s. I d.C. (Freed 1998: 355, fig. 1,1 y 1.4), y también de la Colonia Iulia Karthago en la denominada Fase II (30-70 d.C.), contamos con algunos ejemplares muy próximos (Martin Kilcher 1998: 522, fig. 5, $\mathrm{n}^{\circ} 3-4$ ). Esta pieza conservaba en su interior restos de la degradación del contenido original, del cual se conservaban algunas semillas de uva, que fueron relacionados con huesos de Vitis vinifera ${ }^{12}$. El dato que sí consideramos de interés es que el contenido del envase no pudo ser vínico, o al menos no vino puro, sino mezclado con otros productos (uvas o pasas).

El siguiente fragmento es una Dr. 2/4 con cuello cilíndrico y borde de sección subcircular, tenuemente carenado al exterior, y con unas asas geminadas de las cuales únicamente se conserva el arranque (figura 12, $\mathrm{n}^{\circ} 32$ ). Las características macroscópicas de la pasta de este ejemplar excluyen su procedencia del entorno campano-lacial, ante la ausencia de los característicos desgrasantes volcánicos. Descartando asimismo su posible procedencia tarraconense, contamos también con el tipo de marca, con un nomen desarrollado y una $\mathrm{F}$ tras la interpunción, que se aleja del habitual repertorio abreviado de la epigrafía anfórica tarraconense (Comas 1997). Efectivamente la pieza presenta una marca en el cuello, en cartela rectangular, estampada en vertical algo desplazada, por lo que su trayectoria es oblicua (figura $12, \mathrm{n}^{\circ} 32$ ). Tipológicamente este tipo de ejemplares presenta bastantes similitudes con los tercios superiores de muchas de las Dr. 2/4 documentadas en Pompeya, llegando a compartir con algun ejemplar la peculiaridad de contar con un grafito justo bajo el punto de adhesión de la parte superior de una de las asas (Panella y Fano 1977: 157 y 165, fig. 3), como en nuestro caso.

De la marca AGATHOPV.F únicamente hemos localizado un paralelo en los Castra Praetoria de Roma, aparentemente sobre una Dr. 4 (CIL XV 3396), siendo recogido por Callender (1965: $\mathrm{n}^{\circ}$ 50), que arroja una fecha centrada a mediados del s. I d.C. (CEIPAC $n^{\circ}$ 04998). Pensamos que nos encontramos ante un ánfora vinaria itálica, cuya zona de procedencia no es posible, por el momento, precisar. No obstante, pensamos que una región candidata podría ser algún taller campano o bien el sur de Italia, ámbitos productores muy conocidos por sus caldos en la Antigüedad. No se trataría de la primera documentación de vinos de dicha zona en la Bahía de Cádiz, habiéndose constatado la presencia de una Dr. 2/4 con la doble marca CAEDICIAE/M(arcvs). F(-).VICTRICIS -nombre del fundus y de su propietario- y MARTIALIS -el gestor del taller- en las excavaciones de la Casa del Obispo de Cádiz fechada en momentos muy avanzados del s. II o ya a principios del III d.C. (Bernal y García e.p.: fig. 1, n $\left.{ }^{\circ} 1\right)$.

La última pieza importada es el asa de una Dr. 2/4 de pasta también aparentemente itálica -ajena a las características producciones volcánicas campano-laciales- cuya problemática parece similar al planteamiento esgrimido en el caso precedente.

Plantear, por último, la importancia que el consumo de vino itálico tuvo en la zona del Estrecho de Gibraltar en época altoimperial. Ejemplos de su importancia los tenemos en prácticamente todos los contextos de consumo publicados en los últimos años. Desde la pieza completa de época tardoflavia procedente del abandono de la Venta del Carmen (Bernal y Lorenzo 1998: 73-76, fig. 25, nº 27), pasando por otro ejemplo en los estratos de la Fase I de la villa del Ringo Rango, fechados en torno a época trajanea (Bernal y Arévalo 2002: 197-198, fig. 121, n 17), la excepcional Dr. 2/4 itálica con marca EX FIGLIN(IS) CAESARI(S) del yacimiento costero de Parque Natural, también del s. I d.C. (Bernal et alii 2003: 242, $\mathrm{n}^{\circ}$ 8), o el ánfora ya mencionada de la figlina Caedicia de la Casa del Obispo en Cádiz (Bernal y García e.p.), son exponentes de una tendencia mucho más generalizada -no casual ni aislada geográficamente- de lo que hasta la fecha inducían a pensar los escasos datos publicados.

12. Datos incluidos en el mismo informe del Dr. J.M. Cantoral citado en las notas precedentes. 
INSTALACIONES FLUVIO-MARÍTIMAS DE DRENAJE CON ÁNFORAS ROMANAS: A PROPÓSITO...

211

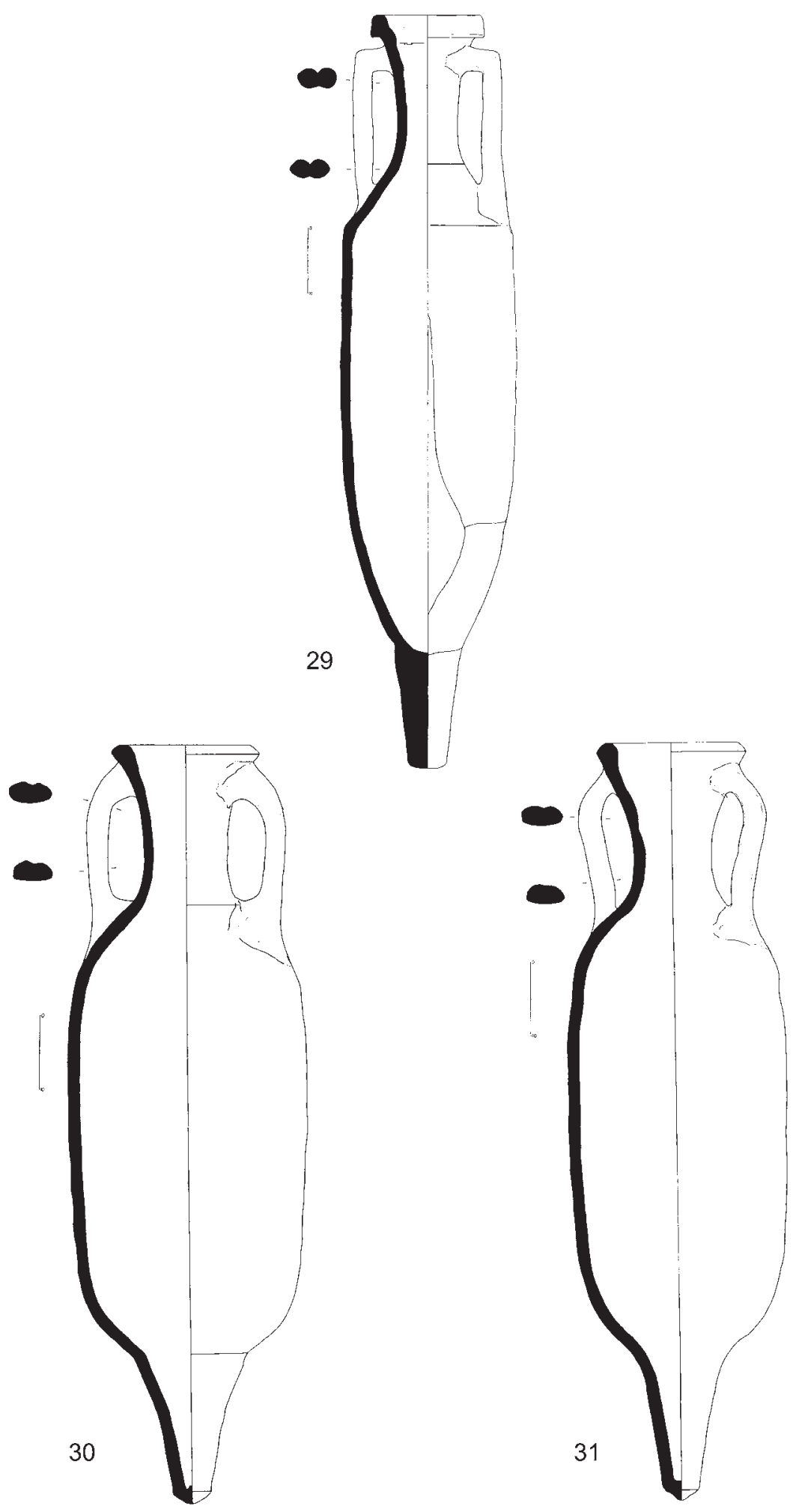

Figura 11.- Ánforas importadas (29.- Dr. 2/4; 30-31.- Dr. 14).

ISSN: 1133-4525 ISSN-e: 2255-3924

SPAL 14 (2005)

http://dx.doi.org/10.12795/spal.2005.i14.07 

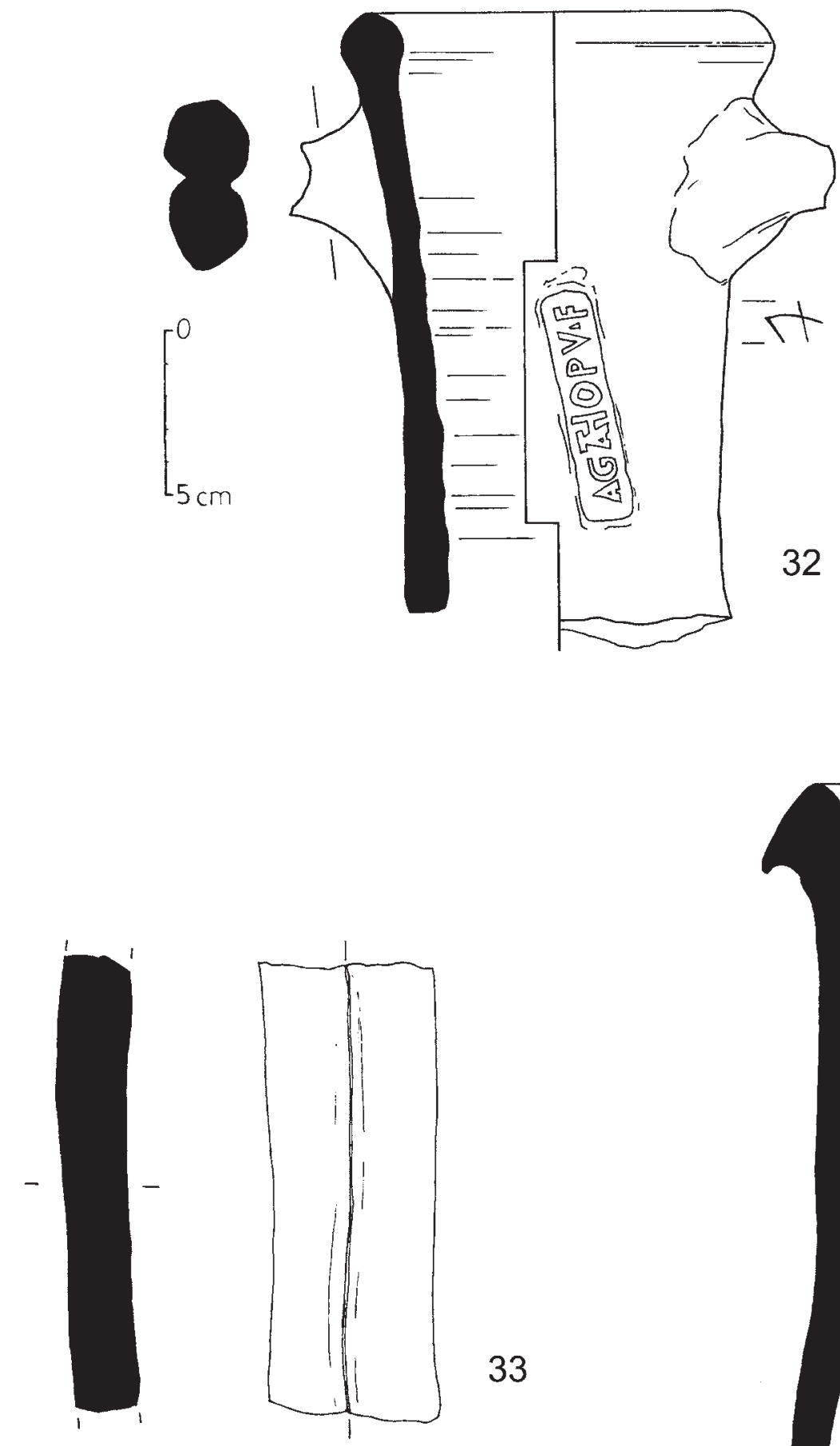

33

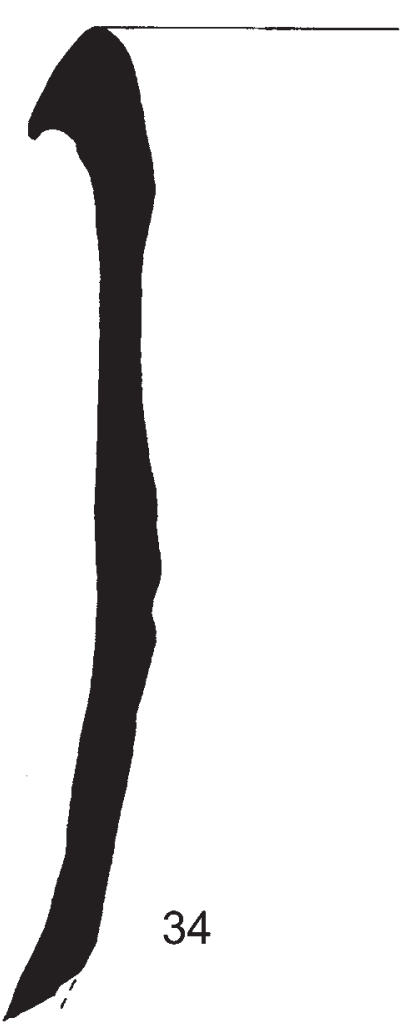

Figura 12.- Ánforas importadas (32-33.- Dr. 2/4) y salsaria local (34.- Beltrán II A). 
La conjunción de todos estos datos induce a proponer una cronología de formación del depósito dentro de la segunda mitad del s. I d.C. teniendo en cuenta la existencia de formas que no parecen penetrar en el s. II d.C. (especialmente las Dr. 7 D/Beltrán II A iniciales y por las Beltrán II B precoces). Dentro de este intervalo, es posible precisar a partir de época flavia especialmente por las dataciones iniciales para algunas formas, caso de las Beltrán IIB precoces o la tipología derivada de las Dr. 20 aparecidas (morfología flavio-trajanea). En este contexto situado en el último tercio del s. I d.C. (70/100 circa) también cuadra la marca de Dr. 20, evidentemente las Beltrán IIA, y la datación ya mencionada de las Dr. 14 lusitanas y tarraconenses. Es decir, nos encontramos ante una estructura edilicia erigida posiblemente en época flavia, cuya época de uso no es posible determinar con claridad ante la ausencia de evidencias al respecto. No obstante, debemos resaltar la total ausencia de artefactos posteriores en todo el yacimiento, por lo que posiblemente su periodo de funcionamiento no debió exceder más allá de avanzado el s. II d.C., época en la cual además parecen abandonarse buena parte de los yacimientos cercanos. Resulta interesante resaltar cómo esta datación coincide con el momento álgido de la mayor parte de estructuras noritálicas y gálicas conocidas -segunda mitad del s. I d.C.- (Cfr. apartado 3.3.2).

\section{VALORACION GENERAL Y PERSPECTIVAS DE TRABAJO.}

Diversos son los trabajos destinados a valorar la terminología latina como vía de aproximación a la comprensión de los tipos de puertos romanos y sus características (Uggeri 1968). Es una cuestión en la cual no vamos a entrar por motivos de espacio, remitiendo a los conocidos trabajos de J. Rougé (1966) o más recientemente de P. Pomey (1997), para incidir en este aspecto. Únicamente queremos recordar la generosidad de la terminología griega y la parquedad de la latina, siendo difícil en este último caso una comprensión clara de las diferencias entre tales términos (portus, limen, salum, emporium...). De ahí que normalmente resulte complejo atribuir una denominación específica a los establecimientos portuarios, salvo en el caso de los grandes puertos del Mediterráneo, militares y con flota. Es por ello que no sea fácil utilizar una denominación precisa para las estructuras halladas en el archipiélago gaditano, quizás restos de una statio. En el caso de los diques o presas fluviales algunos autores han propuesto recientemente la denominación portus, relacionándolos con los sellos anfóricos en Dr. 20 con la fórmula POR o PORT, constituyendo en tal caso no únicamente embarcaderos o muelles, sino también obras de regulación del caudal de los ríos (García et alii 2004). No obstante es una cuestión a valorar en el fututo ante la ausencia de datos explícitos al respecto.

La segunda cuestión sobre la que queremos incidir es en la escasez de paralelos documentados en ámbito hispano. Genéricamente conocemos referencias a obras de adecuación de las orillas del Baetis y de regularización de su cauce (Chic 1990), pero son escasos los estudios arqueológicos detallados al respecto. El caso traído a colación es evidentemente modesto, limitado a estructuras de drenaje sin cualquier otra obra edilicia de embellecimiento. Su importancia deriva en ponernos de manifiesto la existencia de instalaciones portuarias de menor entidad a los grandes puertos "urbanos", cuyo estudio será de gran importancia en el futuro.

La estructura portuaria excavada en Los Cargaderos responde a un pequeño dique, realizado con un sistema de drenaje utilizando ánforas y estacas ligneas, destinado a facilitar el acceso hacia el Caño de Sancti Petri y a los numerosos asentamientos productivos localizados en las inmediaciones (villae). Aparentemente es uno de los primeros ejemplos de estas características documentados en Hispania. Asimismo, este yacimiento cobra importancia por cuanto se convierte en uno de los primeros de Andalucía con la constatación del empleo de madera de pino utilizadas en la arquitectura portuaria.

ISSN: 1133-4525 ISSN-e: 2255-3924

SPAL 14 (2005)

http://dx.doi.org/10.12795/spal.2005.i14.07 
Este hallazgo sirve, a nuestro juicio, para revalorizar la función portuaria de la Bahía de Cádiz en época romana, recurriendo al concepto de complejo portuario de Gadir/Gades. Se trataría de un grupo de unidades de tráfico marítimo integrantes de la misma realidad portuaria global (Blot 2003: 56): en el reciente estudio sobre los puertos antiguos en Portugal, se estudian 35 ejemplos de arqueositios vinculados con actividades marítimas, integrándolos únicamente en XVI Complejos Portuarios. Proponemos aplicar en el futuro el mismo parámetro de estudio para la Bahía de Cádiz, integrando los portus de Gades (Arteaga et alii 2001) con la tupida red de embarcaderos ya pronosticada por C. Pemán (1959), y que encuentra en Los Cargaderos una de sus primeras atestaciones arqueológicas. Evidentemente será necesario recurrir en dicho estudio al análisis combinado de la geomorfología costera y geografía histórica, ayudados por los datos existentes en la cartografía histórica que fosilizan situaciones preexistentes, marco general en el cual se deberán insertar los yacimientos y hallazgos arqueológicos, siguiendo el modelo ya propuesto para Portugal (Blot 2003: 307-308).

Evidentemente, la funcionalidad de la plataforma drenante de las características documentadas en Los Cargaderos está fuera de toda duda. Básicamente su utilidad, como se ha puesto en evidencia en el caso genérico de los embarcaderos, deriva de su uso para el embarque y desembarco de naves, para la contención de las riberas y como sistema de regulación del cauce del curso de agua (Ordóñez 2003: 66). En nuestro caso los embarcaderos servirían para facilitar el atraque sin necesidad de varar. Buenos ejemplos etnoarqueológicos son los proporcionados por el "acostagem" de los barcos en la Lisboa de los ss. XVI a XVIII (Blot 2003: 91 y 237-246).

Desde un punto de vista cronológico, pocas dudas quedan sobre el momento de construcción de la estructura a finales del s. I d.C., posiblemente en época flavia. Desgraciadamente no sabemos hasta cuando se mantiene la misma en funcionamiento, ante la ausencia de otros materiales en las inmediaciones. Resulta interesante comprobar la sintonía cronológica con la treintena de ejemplos franceses de "vides sanitaires", la mayor parte de las que cuentan con dataciones precisas se centran en la segunda mitad del s. I d.C., con un punto álgido en época flavia (Laubenheimer 1998a: 54-69). Algo parecido sucede con los ejemplos noritálicos mencionados en el apartado correspondiente, que se centran entre mediados del s. I a.C. y mediados del s. I d.C. (Pessavento 1998). También es interesante documentar la sincronía cronológica del hasta hoy único puerto hispano bien conocido en cuanto a sus instalaciones en madera se refiere, Oiasso, construido en momentos prácticamente idénticos a los del yacimiento de Los Cargaderos (Urteaga 2003).

Algunos autores han planteado que las obras de adecuación del cauce del Baetis en Hispalis se deben poner en relación con la colonización cesaroaugustea, guiadas por la necesidad de fijar su curso, regular su caudal y proteger a las ciudades de sus orillas mediante presas y diques de tapial o piedra (Chic 1990; 2003). Resulta curioso contrastar que por el momento el único ejemplo gaditano conocido remita a momentos algo posteriores. En cualquier caso, el contexto mediterráneo parece indicar que nos encontramos ante una "moda" que se centra sobre todo entre época augustea y finales del s. I d.C., pues aunque conocemos ejemplos hasta de los ss. IV o V d.C., el 95\% de los casos conocidos se centra en el intervalo comentado.

Es evidente la gran importancia del puerto de Gades entre la Tardía República y el s. I d.C. Baste recordar la ampliación del mismo a cargo de Balbo. Aparentemente el gran impulso constructivo del puerto hispalense se produjo en el s. II d.C., posiblemente como resultado del decaimiento en la actividad del puerto gaditano (Ordóñez 2003: 75). No obstante, este hallazgo isleño de Los Cargaderos permite confirmar la continuidad - e intensidad- de las actividades comerciales aún a finales del s. I, como denuncia la construcción de estas estructuras en el archipiélago gaditano, de las que conocemos únicamente su fecha de construcción, no la de su abandono.

El estudio realizado ha ofrecido, adicionalmente, un reflejo indirecto de la circulación de alimentos en la época. La reutilización de los envases anfóricos en la estructura portuaria de Los 
Cargaderos denota la masiva exportación de salazones béticas a finales del s. I d.C., que constituyen casi el $75 \%$ del total de envases reutilizados ( 25 de 34 ejemplares), al tiempo que reflejan la notable importancia de las importaciones de aceite del valle del Guadalquivir en Dr. 20 (con más del 10\% del total). Asimismo, se ha puesto sobre la mesa una vez más el carácter cosmopolita de la Bahía de Cádiz en ese gran comercio de redistribución, pues se han documentado importaciones en un volumen cercano al $15 \%$ del total, entre las que destacan las salsas de pescado de Lusitania, los vinos itálicos y los caldos de la Tarraconense.

Es bien conocido el carácter público de las obras de regulación del cauce de los ríos y de los caminos de sirga, que suelen estar en manos de las ciudades, pero supervisados por la administración romana (Chic 1990). Recordemos la existencia de personajes tales como Sextus Iulius Posessor, cuyo cargo, procurator ad ripam Baetis, es bien ilustrativo (Ojeda 1995; Ordóñez 2003: 60-63; Parodi 2001). La legislación romana considera que las zonas portuarias son ámbitos de carácter público, algo que sería extensible a la zona documentada a orillas del Caño de Sancti Petri (Digesto 1.8, 3-4 o Inst. Iust. 2.1.1).

La siguiente cuestión sobre la cual permiten profundizar las estructuras portuarias fluvio-marítimas documentadas en Los Cargaderos es en las funciones portuarias de los vici y las villae. Se ha planteado la existencia de zonas portuarias en aglomeraciones secundarias, que servirían de complemento a los grandes puertos. En Portugal se ha propuesto tanto en el Algarve -caso del Cerro da Vila - o en la costa occidental la existencia de pequeños vici portuarios con estructuras de cabotaje (Blot 2003: 141 y 309). También otros autores recientemente plantean las relaciones entre los vici industriales y los fondeaderos, citando explícitamente el caso de Gallineras en la bahía gaditana (García et alii 2004). También en nuestro caso nos encontraríamos ante una situación similar, tratándose de una construcción posiblemente pública, cercana a fundi en los cuales se integrarían las villae maritimae construidas en las inmediaciones. Efectivamente, en el entorno se localizan muchos de estos asentamientos (figura 1). La zona sur y este de la antigua línea costera de San Fernando hace unos dos mil años (que se corresponde grosso modo en la actualidad con el trazado de la llamada carretera de Gallineras) se halla plagada de asentamientos tipo villa asociados casi siempre a establecimientos industriales (centros industriales y/o alfares). Destaca de todas estas villae la ubicada en el extremo sur de la isla, el yacimiento de Gallineras-Cerro de los Mártires, que podemos utilizar de modelo paradigmático de este tipo de instalaciones en el ámbito insular gaditano.

El yacimiento de Los Cargaderos ha sido recientemente interpretado como parte de un posible muro de acarreo de una salina de época romana (Alonso, Gracia y Benavente 2004: 279-280). La revisión de la cartografía de la zona (existente desde la segunda mitad del s. XVI) revela la existencia de campos de cultivo en el emplazamiento de la salina de S. Cayetano, si bien ya para finales del s. XVII encontramos referencias a "albinas perdidas", salinas ya en desuso (Concepción 1690), por lo que debemos suponer un inicio de la actividad a comienzos de dicha centuria. Es indudable la necesaria existencia de actividades salineras en la isla para época romana como apoyo a la industria conservera de la bahía aprovechando las condiciones naturales (abundantes marismas inundables), aunque hoy por hoy y dada la naturaleza arqueológica de los enclaves salineros (tajos realizados sin dejar apenas restos materiales contextualizados) es casi imposible probar físicamente la existencia de dicha industria en la zona. Por ello, la hipótesis de interpretar el alineamiento de ánforas como muro de una salina no es del todo improbable aunque parece que debe ser relegada a un segundo plano y a un estado más avanzado de las investigaciones paleogeográficas en la Bahía de Cádiz. Otros yacimientos situados en terrenos actualmente ocupados por salinas de construcción moderna-contemporánea como Río Arillo, Salina Tres Amigos o Almadraba podrían ser también interpretados como salinas romanas, si bien la naturaleza de los restos muestra de forma clara que no por estar situados en terrenos inundables los restos antiguos corresponden siempre a actividades

ISSN: 1133-4525 ISSN-e: 2255-3924

SPAL 14 (2005)

http://dx.doi.org/10.12795/spal.2005.i14.07 
salineras: Río Arillo, con pavimentos de opus signinum y sillarejo, parece corresponderse con el paso del acueducto Tempul-Gades; en el yacimiento de Almadraba hemos podido localizar los restos de un posible asentamiento rural altoimperial y un alfar del s. I d.C., etc. (problemática en Bernal et alii 2004).

Nuestra interpretación del yacimiento difiere en sentido funcional de la anterior: se trataría de una plataforma de carga y descarga que además actuaría como elemento de refuerzo y contención de la orilla del caño, al modo de las estructuras que conocemos por las fuentes literarias que existieron para regularizar y encauzar los cursos de agua. No debemos olvidar en este sentido el topónimo del yacimiento, "Los Cargaderos", procedente de la nomenclatura utilizada oralmente en la zona para señalar a este lugar. Si bien el yacimiento está localizado en los terrenos pertenecientes a la salina San Cayetano, a escasos cien metros del yacimiento, existe un pequeño pantalán aún en uso en la actualidad del cual quizá provenga dicho topónimo. Asimismo, en la zona aún se mantiene en pie, aunque en proceso de deterioro, un molino que parece ostentar esta denominación ("molino de Los Cargaderos"). A pesar de que esta zona se conozca popularmente como Los Cargaderos, en el estudio que hemos realizado en relación con el topónimo, tenemos que indicar que en los catastros consultados no hemos localizado dicho topónimo para denominar a esta zona. En este sentido, en los planos del Catastro del Término Municipal de San Fernando realizado en 1950 por el Instituto Geográfico y Catastral, conservados en la Gerencia Municipal de Urbanismo del Ayto. de San Fernando, y en concreto en el Polígono 7, si bien ya se incluye el pantalán ubicado en el Caño de Lavaera, el lugar exacto donde se ubica el yacimiento se denomina Los Ángeles de San Cayetano, no apareciendo el topónimo de Los Cargaderos. En la misma dirección apunta el plano 2/14 del Plan General de Ordenación Urbana redactado en febrero de 1987 y aprobado finalmente en 1992, en el cual ya la zona se denomina de manera general como "salinas San Cayetano".

Por su parte, los pilotes de madera de pino documentados entre las ánforas crearían una estructura que daría uniformidad y cohesión al amontonamiento de ánforas, siendo cubierta la misma por un relleno de tierra y finalmente un "pavimento" de pequeños guijarros. P. Madoz (1987) cita múltiples embarcaderos de este tipo para el s. XIX a lo largo del caño de Sancti Petri, a través de los cuales se realizaban análogas transacciones mercantiles, por lo que debemos suponer que en un momento en que el calado y la anchura del canal permitían una mejor navegación estas actividades se multiplicarían, motivadas por un poblamiento más intenso y con mayor vocación comercial de sus riberas. El uso de ánforas estaría motivado por cuestiones relacionadas con el peso de la estructura: un muro de sillares pesado se hundiría en los suelos blandos de las marismas de la zona, por lo que se usaron ánforas para edificar una estructura ligera a modo de embarcadero. Sin duda, la estimable cantidad de enclaves rurales (con factorías de salazones y alfares) ubicados en la costa del caño estaban orientados a la exportación de los productos por ellos producidos-derivados de las conservas de pescado y en mucha menor medida agropecuarios- por lo que la lógica salida de estos serían barcos varados frente a ellos, que utilizarían embarcaderos como el que aquí presentamos para tales fines. El yacimiento de Los Cargaderos se sitúa exactamente alineado con la villa excavada en la Avda. Constitución, ubicada en la antigua línea de costa y dotada de amplias instalaciones industriales, por lo que debemos relacionarlo con ella (asimismo las cronologías barajadas para ambos parecen corresponderse). Estaríamos hablando por tanto de una estructura realizada en un sector de poco calado en una zona próxima a la villa (unos 300/350 m adentrándose en el caño) que ayudaría a la carga en pequeñas embarcaciones de los productos propios del asentamiento para su salida. En la zona de la salina El Estanquillo, frente a la villa de Gallineras y junto al asentamiento de Almadraba, los hallazgos cerámicos en zonas ocupadas actualmente por salinas o incluso marismas vírgenes (ánforas y terra sigillata, en ocasiones formas completas) delatan la probable existencia de otros embarcaderos del mismo tipo que el ahora estudiado. 
Una línea de investigación interesante para el futuro es la determinación de la red de canales existentes tanto a ambos lados del Caño de Sancti Petri como en aguas interiores de la bahía gaditana. Ya citados por Estrabón (III,2,5), se trata de una cuestión que pensamos es clave para la comprensión de la articulación interna del territorio en el antiguo archipiélago gaditano. Esta línea de trabajo podría ser abordada en la Bahía de Cádiz en el caso de contar con una prospección a escala microespacial de la zona de marisma consolidada, cuyos resultados, pensamos, serían complementarios a los aportados por otras fuentes, especialmente la cartografía histórica. El futuro se muestra prometedor en dicha línea.

En el caño de Sancti Petri debió ser muy frecuente la recurrencia a barqueros fluviales para facilitar el tránsito de mercancías. Estas corporaciones son bien conocidas en época romana, estando atestiguadas epigráficamente en Hispania con al menos cuatro hallazgos hispalenses de mediados del s. II d.C., conocidos como lyntrarii y scapharii (problemática en Ordóñez 2003: 60).

Debemos comentar adicionalmente la gran tradición de los barqueros fluviales, conocido sistema de transbordo de las mercancías entre las grandes naves onerarias y las barcazas (scaphae o naves pequeñas), cuya accesibilidad a los puertos interiores está fuera de toda duda (Casson 1965). Basten las referencias de Estrabón (III,2,6) o Plinio (NH XIX, 4) al respecto para valorar su importancia. Un ejemplo podría ser el conocido área portuaria de Valentia, en la Antigüedad a $3 \mathrm{kms}$. del mar (Burriel, Ribera y Serrano 2003: 128-129). En Lisboa también se plantea su utilización, teniendo en cuenta la existencia de paralelos etnográficos hasta mediados del s. XX (Mantas 2003: 25-26). Debemos destacar en este contexto los ya citados caminos de sirga, paralelos a las orillas y que permitían el avance de las naves de poco calado. Se conocen relieves al respecto y es una cuestión bien conocida en los principales ríos hispanos como el Ebro (Aguarod y Erice 2003: 151) o el Guadalquivir (Chic 1990; Parodi 2001). Por otro lado, no debemos olvidar la existencia en el mundo antiguo de los "puentes de barcazas", como ilustra magistralmente la representación del de Arles en el mosaico de la Statio 27 del Foro de las Corporaciones de Ostia, de mediados del s. II d.C. (Long y Sintes 2003: 184). Es un modelo mixto con un tramo sobre barcazas, otro de obra y dos tramos levadizos, citado por Ausonio, Casiodoro, Gregorio de Tours y otros autores antiguos (Sintes 1999-2000).

Respecto a la navegación en el Caño de Sancti Petri, contamos con algunos indicios remotos, datables en diversos momentos del Neolítico pero especialmente en el II milenio a.C., que permiten suponer un paso a través de las aguas del caño desde el continente a las islas gaditanas (Ramos, 1993; Castañeda, 1997), yacimientos cuya ubicación en las laderas que caen hacia la orilla del caño parecen indicar una estrecha relación de explotación y uso del mismo. Desgraciadamente de época romana los únicos datos arqueológicos existentes hasta la fecha son los que aporta el presente trabajo, limitados a documentar la presencia de los testimonios de este embarcadero en la zona de Los Cargaderos. Para época medieval y moderna, por el contrario, contamos con multitud de referencias explícitas en las fuentes literarias (Abellán 1996; Franco 1995).

Este yacimiento gaditano estudiado vuelve a poner sobre la mesa la evidente descompensación entre las fuentes literarias y las arqueológicas, como se ha planteado explícitamente para el caso del puerto de Sevilla (Ordóñez 2003: 65-66) y más genéricamente para otros ejemplos de la Bética (García et alii 2004), destacando entre ellos el caso magistral de Carteia. No contamos con datos de este tipo de estructuras de drenaje portuarias en las fuentes, por lo que los estudios estrictamente arqueológicos son claves para avanzar al respecto. Además deben tratarse en el futuro de investigaciones en el seno de la "Arqueología Litoral” o "Arqueología del Medio Acuático", propuesta esta ultima en el marco de la conexión mar y tierra, terminología que se prefiere en vez de marítima, náutica, subacuática, submarina o naval (Blot 2003: 27-28). 
Para el estudio de los fondeaderos y los varaderos fluviales, la Bahía de Cádiz presenta óptimas potencialidades de conservación. Sus aguas interiores y las zonas inundables son proclives para la conservación de la materia orgánica por la existencia de lodo, que genera ambientes anaeróbicos que sí permiten, potencialmente, la preservación de madera. Esta cuestión ya ha sido puesta de manifiesto para otros ámbitos cercanos, caso de los estuarios y espacios endolagunares lusitanos, actualmente en cultivo (Blot 2003: 22-23 y 309). Los restos de la embarcación fechada en época medieval en El Portal -Jerez de la Frontera-, a la cual aparecieron asociados evidencias de un embarcadero con estacas clavadas en el fango (Blanco 1981), se sitúan en esta misma línea ${ }^{13}$.

El hallazgo de esta estructura de drenaje en San Fernando muestra, una vez más una cuestión tecnológica importada del ámbito itálico, pues no se conocen ejemplos de época precedente -mundo púnico o tardopúnico-, cuya importancia en la manufactura de envases es bien conocida. Posiblemente responda a una introducción de la mano de agrimensores en época republicana o tardo-republicana, si bien por el momento el único ejemplo conocido se limita a momentos muy avanzados del s. I d.C. Como ya hemos comentado, la influencia tipológica procede posiblemente en origen de las llanuras del Po y de la laguna de Venecia, lugares con los que la Baetica mantiene una relación económica muy bien conocida especialmente a partir de época augustea e inicios del s. I d.C. (Modrzewska 1996). Quizás fruto del intercambio comercial hayamos asistido al tránsito de población y evidentemente de ideas, entre las cuales debemos situar a estas pequeñas obras de ingeniería, fruto de la mos latina, destinadas a mejorar la practicabilidad de las zona de marisma consolidada. Este mismo fenómeno ya ha sido documentado arqueológicamente en la bahía gaditana en el caso de la tecnología alfarera (Bernal et alii 2004).

Por último, incidir en el hecho de que la estructura objeto de estudio ha permitido una vez más detectar esos fenómenos de "longue durée" tan habituales hasta la Revolución Industrial. Normalmente la localización de los puertos está supeditada a una serie de condicionantes geomorfológicos y de dinámica litoral que propician una localización ininterrumpida a lo largo del tiempo. Un buen ejemplo sería el ilustrado por el puerto de Caesaraugusta, cuyas estructuras portuarias fluviales romanas están en el mismo sitio donde han estado desde el s. XVI y la actualidad las rampas de acceso al río (Aguarod y Erice 2003: 144).

Asimismo, es necesario destacar que otra de las líneas de trabajo necesarias para el futuro es la aplicación de estudios de reconstrucción paleoambiental para determinar cuestiones claves como el trazado del caño en época romana, su calado y los canales interiores conocidos indirectamente por cartografía histórica. En España cada vez hay más estudios al respecto, como los realizados en general para la Bahía de Cádiz (Alonso, Gracia y Benavente 2004) y específicamente para el puerto de Gadir/Gades (Arteaga et alii 2001), o los ejemplos de la ciudad-portuaria de Mellaria o más recientemente la de Baelo Claudia (Alonso y García 2003). En ámbito mediterráneo los ejemplos se multiplican, desde el caso de Aquileia (Carre, Marocco, Scotti y Pugliese 2004), pasando por Sidón (Morhange et alii 2003) o la propia Alejandría (Goiran, Bourcier y Morhange 2003).

Nos encontramos, por tanto, ante nuevos hallazgos que permiten plantear la fertilidad de estas líneas de investigación en el futuro, ante la escasez de datos al respecto, y que sitúan a la Bahía de Cádiz y a todo su litoral como uno de los espacios privilegiados en el futuro para avanzar en estos temas y otros similares vinculados con el aprovechamiento de los recursos del mar.

13. Aunque estas estructuras se han fechado en época medieval, en las ilustraciones se muestran algunos pivotes de ánforas Dr. 7/11, con fallos de horno (Blanco 1981: 83 infra y 85, foto 9). Podría tratarse de un testimonio de un embarcadero asociado a un alfar altoimperial próximo, modelo similar al de Los Cargaderos. Planteamos la conveniencia en el futuro de revisar los datos de este yacimiento jerezano. 


\title{
ANEXO I. \\ ANÁLISIS DE LOS RESTOS DE MADERAS DEL EMBARCADERO ROMANO DE LOS CARGADEROS.
}

\author{
P. UZQUIANO. \\ Dpto. Prehistoria e $\mathrm{H}^{\mathrm{a}}$ Antigua. Universidad Nacional de Educación a Distancia.
}

\section{Identificación y características anatómicas}

Hemos procedido al análisis e identificación botánica de restos de madera procedentes del embarcadero de época romana de Los Cargaderos (San Fernando, Cádiz). Las muestras han sido todas identificadas como Pino. La sección transversal nos muestra claramente el leño temprano o de primavera y el leño tardío o de verano, con canales secretores no muy grandes. La posición de éstos se encuentra en el leño tardío pero también algunos de ellos aparecen en el leño temprano (Jacquiot 1955; Vernet et al. 2001). Esta característica aproxima las muestras analizadas a la especie Pinus halepensis o Pino carrasco.

Por otro lado, hemos observado en el plano radial que las paredes de las fibras traqueidas transversales no son dentadas, y el número de puntuaciones observadas en los campos de cruce oscilan entre 2 puntuaciones pequeñas por campo, 2/3 y más raramente, 4 puntuaciones. Estas características se observan no solamente en el Pino carrasco, sino también en Pinus pinea o Pino piñonero (Jacquiot 1955; Vernet et al. 2001). No obstante el plano transversal del Pino piñonero muestra unos canales secretores más grandes, y alineados todos en el leño tardío, o hacia la transición leño temprano/leño tardío, pero nunca en el leño temprano. Teniendo en cuenta todos los detalles anatómicos observados es probable que las muestras se encuentren más próximas al Pinus halepensis sin descartar por ello Pinus pinea. Pinus halepensis prolifera sobre substratos calcáreos a baja altitud y en proximidad de la costa (Rivera y Obón de Castro 1991).

Las dos especies de pino se encuentran en la transición de los pisos bioclimáticos termo-mesomediterráneo, la distribución geográfica de ambas discurre por zonas próximas a la costa y a baja altitud (Gil et al. 1996; Aranzazu et al. 1997), lo único que varía es el tipo de substrato: suelos arenosos o dunas litorales para Pinus pinea, substrato calizo para Pinus halepensis. El depósito donde se hallaron estos restos se encuentra en la Bahía de Cádiz, una zona de marismas y suelos arenosos muy aptos para la proliferación de Pinus pinea, pero no se sabe con certeza si la procedencia de estas maderas es inmediata (de esta zona de marismas con pino piñonero) o por el contrario, más alejada. Hemos de señalar que Pinus halepensis en la Península Ibérica tiene una repartición más oriental, toda la vertiente Mediterránea, llegando por el sur hasta la Bahía de Algeciras (Gil et al. 1996).

\section{Etnobotánica del pino carrasco y del pino piñonero}

Teniendo en cuenta que las maderas analizadas provienen de una construcción, solamente señalaremos las características etnobotánicas de estas especies en lo referente a su madera (Rivera y Obón de Castro 1991). El pino carrasco pose una madera de color muy claro, blanquecino, de grano fino y muy resistente a la compresión. Es semipesada y muy dura, por lo que no suele usarse en carpintería. Los troncos presentan una forma tortuosa y son ricos en resina, de la cual se fabrica, mediante destilación de las maderas, la pez, brea o alquitrán uno de los productos de mayor uso en la Antigüedad (Rivera y Obón de Castro 1991). Esta fue impermeabilizante universal, que se empleó para calafatear los barcos a fin de sellar las juntas de las maderas y protegerlas frente al agua (Gil et al. 1996).

La madera de pino carrasco fue la que se utilizó en mayor medida en la construcción naval de época romana. La causa de dicha utilización eran sus fustes curvos ya que de ellos se obtenían fácilmente piezas curvas y sinuosas. Además la proximidad de los bosques de carrasco a los astilleros facilitaban 
la construcción de barcos. No obstante algunos autores atribuyen estas características al pino piñonero (Aránzazu et al. 1997). El pino piñonero tiene una madera de color blanco amarillento en la albura y rojizo en el duramen interior, con abundantes nudos, resinosa y relativamente pesada. Resulta difícil de trabajar, se contrae mucho si bien es flexible y resistente a la humedad, por lo que suele emplearse para entibado de minas, traviesas de ferrocarril y rara vez en construcción (Rivera y Obón de Castro 1991). Este último supuesto queda desmentido por otros autores que indican un amplio uso de la madera de este pino en la obtención de vigas, tablas y casi todas las partes de las que se componen nuestras casas: cubiertas o techumbres, puertas, ventanas, mesas, arcas, escritorios... (Aránzazu et al. 1997). En Andalucía se ha empleado para la construcción de barcos pequeños, para el tránsito de los ríos. Esta madera también se empleó en la construcción de norias de cangilones en las minas romanas, destinadas a extraer el agua al exterior.

\section{Los datos paleobotánicos y las fuentes escritas sobre los pinos en la Península Ibérica}

Los datos paleobotánicos de estas dos especies de pino proceden en su mayoría de los análisis antracológicos. En menor medida, de datos polínicos y de macrorrestos vegetales. La utilización del piñón en la dieta de los primitivos pobladores nos permite contar con datos pertenecientes a Pinus pinea en yacimientos del sur peninsular como la cueva de Gorham en Gibraltar, donde se encontraron carbones de madera y fragmentos de piñas en niveles del Musteriense y del Paleolítico Superior (Metcalfe 1958). La datación más antigua es de 49.2 Ka. BP. Asimismo encontramos restos de carbones, fragmentos de piñas y cáscaras de piñones en los niveles de ocupación excavados en la sala del Vestíbulo de la Cueva de Nerja, desde el Paleolítico Superior (Badal 1995). La fecha más antigua obtenida procede del nivel Solutrense $18.9 \mathrm{Ka}$. BP. Su presencia es continua desde el Paleolítico al Neolítico (6.4 Ka. BP). Carbones de madera de pino piñonero aparecen en los sedimentos de otras ocupaciones neolíticas del territorio peninsular: Cova de les Cendres en Alicante (Badal 1995), Hoyo de la Mina en Málaga, Cueva de La Vaquera en Segovia (Uzquiano 2002) y Lloma del Betxi en Valencia (Grau 1991).

En la Protohistoria encontramos referencias antracológicas en los poblados prerromanos de Soto de Medinilla y Medina del Campo en Valladolid (Uzquiano 1995), durante el período orientalizante en el Palacio-Santuario de Cancho Roano (Uzquiano, en prensa). En Portugal existen datos paleobotánicos (restos de piñas) desde el Mesolítico en adelante, en yacimientos como El Zambujal y Vilanova de Sao Pedro (Hopf 1979; Pinto da Silva 1971). No poseemos datos antracológicos de época romana referentes a la utilización del pino piñonero.

En cuanto al pino carrasco los datos antracológicos son tan antiguos como los del pino piñonero y sobre todo, mucho más numerosos. Encontramos datos desde el Musteriense en Carihuela (40-34 Ka. BP) (Carrión 1992b) y en Cova Beneito (40-30 Ka. BP) (Carrión 1992a). En la Cueva de Nerja (Badal 1995) encontramos maderas de pino carrasco desde fines del Solutrense, durante el Magdaleniense, Epipaleolítico y Neolítico (17.9-6.4 Ka. BP). Otros yacimientos neolíticos con datos antracológicos y polínicos de Pinus halepensis son: Cendres, Bolumini, Cova de l'Or, Les Jovades, Niuet (Badal 1995), Recambra (Grau 1984), Cova Fosca (Yll 1988) en el País Valenciano y Can Sadurní, Can Tintorer (Ros 1992) en Cataluña. Durante el Calcolítico y la Edad del Bronce son numerosos los datos procedentes de yacimientos andaluces como Los Millares, Cerro de la Virgen, El Malagón, Fuente Amarga, Loma de la Balunca, Terrera del Reloj, Castellón Alto, Fuente Alamo (Rodríguez 1992); en Cataluña tenemos los datos de Cova del Frare, La Fonollera, Folibernat y de Punta Farisa (Ros 1992); en el País Valenciano, los yacimientos de Lloma del Betxi y El Puntal dels Llops (Grau 1991). De época ibérica, Ronda la Vieja en Andalucía (Rodríguez et al. 1992), Puntal dels Llops, Castellet de Bernabé, Los Villares y Cabezo Lucero en el País Valenciano (Grau 1991) y Puig Castellet (Ros 1992) en Cataluña. Asimismo aparecen datos arqueobotánicos de época griega 
en Ampurias (Hopf 1991) tanto en la ciudad como en la necrópolis. De época romana, tardorromana y visigoda contamos con los datos procedentes de diferentes lugares de excavación del asentamiento de Valentia (Grau 1991).

Los pinos en la Península Ibérica se han considerado siempre como especies exóticas introducidas, como es el caso de Pinus pinea o el de Pinus pinaster o Pino resinero; o producto de repoblaciones de época histórica reciente (Gil et al. 1996). Por ello hemos considerado conveniente incluir una descripción detallada de todos los datos paleobotánicos anteriores a la presencia romana en la Península. La presencia tan antigua de estos dos taxones queda por tanto atestiguada, demostrando que los pinos son especies autóctonas, testigos relictuales de episodios climáticos anteriores al Holoceno.

Las fuentes escritas se prestan a confusión para identificar estas dos especies de pino debido a la nomenclatura utilizada por los autores clásicos. Teofrasto y Plinio utilizaron los términos peuke y pitys para referirse a los pinos, atribuyéndoles un carácter doméstico, debido a la presencia de sus semillas como alimento. Este atributo refuerza su identificación con Pinus pinea y permite inferir su temprana unión a la actividad humana. Pero en lo referente a otros usos como la construcción naval, autores como Plutarco aluden al empleo de pino piñonero y de otras especies de pino próximas (no sabemos si habría que incluir Pinus halepensis), para la construcción de barcos y para la obtención de pez. La cita textual (Moralia, VIII, V,3) se presta a confusión: “el pino (pitys) con sus especies próximas (peukai) y el pino piñonero (strobiloi), proporcionan la madera más apreciada para las construcciones navales y para calafatear con pez y resina, sin las cuales los barcos no podrían ser utilizables en el agua" (Clement y Hoffleit 1969). Hispania sería por tanto, productora de navíos y de pez, por lo que el impacto sobre los pinares debió de ser intenso.

Ante la confusión que presenta la nomenclatura para referirse a las especies actuales de pinos, es preferible contar con datos paleobotánicos paralelos. Un análisis reciente de las maderas procedentes de barcos romanos (Rival 1991) demostró el empleo del pino carrasco, deduciéndose un consumo masivo durante la Antigüedad.

\section{Conclusiones}

En resumen, a nivel anatómico las muestras analizadas presentan caracteres más próximos de Pinus halepensis, si bien no descartamos Pinus pinea. En lo referente a su distribución geográfica y tipo de substrato, Pinus pinea es el candidato más idóneo si consideramos la proximidad de estas comunidades como factor determinante en su utilización. No obstante desconocemos si la procedencia de estas maderas era inmediata o más alejada. Desde un punto de vista etnobotánico parece ser que ambas especies son idóneas para la construcción naval, y son resistentes a la humedad sobre todo si van impermeabilizadas con pez, un producto que se obtiene destilando la resina que ambas especies producen.

A nivel de fuentes escritas las dos especies han sido documentadas, pero únicamente analizando su madera puede saberse con objetividad de que especie de pino se trata. A la luz de los resultados antracológicos del territorio peninsular, Pinus halepensis aparece mejor documentada, tanto en extensión (número de yacimientos) como a nivel cuantitativo (número de fragmentos) en los yacimientos considerados. Pinus pinea aparece en buena parte de estos yacimientos asociado a restos de piñas y cáscaras de piñones, deduciéndose una utilización ligada a la alimentación de los grupos humanos. Su presencia a nivel cuantitativo también es menor.

Son muy escasos los análisis antracológicos de época romana en la Península Ibérica. Valentia (Grau 1991), las necrópolis gallegas de Lucus Augusti (Aira y Uzquiano 1996) y recientemente la villa rural de San Pelayo son por el momento los únicos trabajos realizados. 


\section{ANEXO II. \\ DATACIÓN POR C14 DE LOS RESTOS DE MADERA DE LOS CARGADEROS.}

D. Hood (Beta Analytic Inc.)

La muestra remitida al Laboratorio Beta Analytic Inc. (University Branch, Miami, Florida, EE.UU.) se corresponde con el fragmento de mayores dimensiones de los cuatro conservados (Apartado 3.1, Fragmento 01).

\section{Sample Data:}

Report of Radiocarbon Dating Analyses (report date 25/01/2005)

Beta - 200118; Sample: Cargaderos 01; Analysis: Radiometric-Standard delidery

Material/pretreatment: (wood): acid/alkali/acid

2 sigma calibration: Cal BC 110 to Cal AD 130 (Cal BP 2060 to 1820) 95\% probability

Measured Radiocarbon Age: 2010 +/- 60 BP

13C/12C Ratio: -26.7 o/oo; Conventional Radiocarbon Age: 1980 +/- 60 BP

Intercept of radiocarbon age with calibration curve: Cal AD 30 (Cal BP 1920).

1 Sigma calibrated result (68\% probability): Cal BC 40 to Cal AD 80 (Cal BP 1990 to 1870).

References: Database used INTC AL 98; Calibration Database; Editorial Comment: Stuiver, M., van der Plicht, H., 1998, Radiocarbon 40 (3), pxii-xiii; INTCAL 98 Radiocarbon Age Calibration: Stuiver, M. et al, 1998, Radiocarbon 40 (3), p 1041-1083; Mathematics: A Simplified Approach to Calibrating C14 Dates; Talma, A.S., Vogel, J.C., 1993, Radiocarbon 35 (2), p. 317-322. 


\section{BIBLIOGRAFÍA}

ABELLÁN PÉREZ, J. (1996): El Cádiz islámico a través de sus textos. Cádiz.

AGUAROD OTAL, C. y ERICE LACABE, R. (2003): "El puerto de Caesaraugusta", en Puertos fluviales antiguos: ciudad, desarrollo e infraestructuras (G. Pascual y J. Pérez eds.): 143-155. Valencia.

AIRA, M.J. y UZQUIANO, P. (1996): “Análisis polínico e identificación de carbones en necrópolis gallegas de época romana", en Lucus Augusti: I. El amanecer de una ciudad : 47-53. Catalogación Arqueológica y Artística de Galicia del Museo de Pontevedra. Fundación Pedro Barrié de la Maza.

ALONSO, C. y GARCÍA, E. (2003): "Geopolítica imperial romana en el Estrecho de Gibraltar: el estudio geoeléctrico del Puerto de Bolonia (Tarifa, Cádiz) y el emplazamiento de Mellaria”, Habis 34: 187-200.

ALONSO, C.; GRACIA, F.J. y BENAVENTE, J. (2004): "Cambios litorales en época histórica en la Bahía de Cádiz", Las industrias alfareras y conserveras fenicio-púnicas en la Bahía de Cádiz. Actas de los XVI Encuentros de Historia y Arqueología (San Fernando, 2000): 263-289. Córdoba.

ALONSO, C.; GRACIA, J. y MENANTEAU, L. (2003 a): "Las salinas de la Bahía de Cádiz durante la Antigüedad. Visión geoarqueológica de un problema histórico", Spal 12: 317-332. http://dx.doi. org/10.12795/spal.2003.i12.13

ALONSO, C.; OJEDA, R.; MENANTEAU, L. y GRACIA, J. (2003 b): “Análisis geoarqueológico del sector meridional de Baelo Claudia (Tarifa, Cádiz)", Boletín del Instituto Andaluz del Patrimonio Histórico 43: 58-74.

AMARO, C. (1995): The archaeological site Rua dos Correeiros, Lisboa.

ARANEGUI, C. y MANTILLA, A. (1987): "La producción de ánforas Dr. 2/4 en Sagunto", El Ví a l'Antiguitat. Economia, producció y comerç al Mediterrrani Occidental: 100-104. Badalona.

ARANZAZU, M.; GORDO, J.; DE MIGUEL, J.; MUTKE, S.; CATALÁN, G.; IGLESIAS, S. y GIL, L. (1997): Las regiones de procedencia de Pinus pinea, L. en España. Organismo Autónomo de Parques Nacionales. Ministerio de Medio Ambiente. Madrid.

ARTEAGA, O.; KÖLLING, A.; KÖLLING, M.; ROOS, A. M.; SCHULZ, H. y SCHULZ, H. D. (2001): "El puerto de Gadir. Investigaciones geoarqueológicas en el casco antiguo de Cádiz", Revista atlántica-mediterránea de Prehistoria y Arqueología Social IV: 345-416. Cádiz.

ARTEAGA, O. y ROOS, A. M. (e.p.): "Proyecto Antípolis. Introducción a la geoarqueología de la Bahía de Cádiz", XIX Encuentros de Historia y Arqueología «Geoarqueología e historia de la Bahía de Cádiz. Proyecto Antípolis» (San Fernando, noviembre de 2003).

BADAL, E. (1995): "La vegetación carbonizada. Resultados antracológicos del País Valenciano", en El Cuaternario del País Valenciano. Departamento de Geografía. Universitat de Valencia: 217-226.

BALISTA, C. (1998): "Risanamenti preventivi dei terreni ottenuti con sistemazioni di anfore: modelli e processi dall'area preiurbana di Padova", Bonifiche e drenaggi con anfore in epoca romana : aspetti tecnici e topografici: 23-35. Módena.

BARRAUD, D. (2003) : "Burdigala y su puerto”, AA.VV. Gijón. Puerto romano. Navegación y comercio en el Cantábrico durante la Antigüedad (C. Fernández Ochoa ed.), Madrid: 213-221.

BELTRÁN LLORIS, M. (1969): “Las ánforas romanas del Museo de Zaragoza”, X Congreso Nacional de Arqueología: 408 ss. Zaragoza.

BELTRÁN LLORIS, M. (1970): Las ánforas romanas en España, Zaragoza.

BELTRÁN LLORIS, M. (1977): "Problemas de la morfología y del concepto histórico-geográfico que recubre la noción tipo. Aportaciones a la tipología de las ánforas béticas", Methodes classiques et methodes formelles dans l'étude des amphores: 97-131. Ecole Française de Rome, Roma. 
BELTRÁN LLORIS, M. (1985): “Arqueología urbana en Zaragoza”, Arqueología de las ciudades modernas superpuestas a las antiguas, Madrid.

BERNAL CASASOLA, D. (1997): Economía y comercio de la Bética mediterránea y del Círculo del Estrecho en la Antigüedad Tardía a través del registro anfórico, Tesis Doctoral inédita, Universidad Autónoma de Madrid.

BERNAL CASASOLA, D. (1998): "Las ánforas de producción local: tipología, caracterización y epigrafía", Excavaciones arqueológicas en el alfar romano de la Venta del Carmen (Los Barrios, Cádiz). Una aproximación a la producción de ánforas en la Bahía de Algeciras en época altoimperial: 143-198. Madrid.

BERNAL, D. y ARÉVALO, A. (2002): “Las ánforas de importación”, en Excavaciones arqueológias en la villa romana del Puente Grande (Los altos del Ringo Rango, Los Barrios, Cádiz). Una ventana al conocimiento de la explotación económica de la Bahía de Algeciras entre el s. I y el V d.C. (D. Bernal y L. Lorenzo eds.): 189-216. Huelva.

BERNAL, D.; DÍAZ, J. J.; EXPÓSITO, J. A.; SÁEZ, A. M, LORENZO, L. y SÁEZ, A. (2003): Arqueología y Urbanismo. Avance de los hallazgos de época púnica y romana en las obras de la carretera de Camposoto (San Fernando, Cádiz), Cajasur, Jerez de la Frontera.

BERNAL, D. y GARCÍA, E. (e.p.): “Gades como centro de consumo entre el s. II a.C. y la Antigüedad Tardía. Aportaciones del registro anfórico procedente de las excavaciones en la Casa del Obispo", en J.M. Gener y M.A. Pajuelo eds., Excavaciones en la Casa del Obispo, Cádiz, en prensa.

BERNAL, D.; GARCÍA, R.; SÁEZ, A.M.; DÍAZ, J.J. y MONTERO, R. (2004 b): “Ánforas locales e importadas del yacimiento de Los Cargaderos. Caracterización arqueométrica de algunos talleres alfareros de época romana de San Fernando (Cádiz)", Avances en Arqueometría. Actas V Congreso Ibérico de Arqueometría: 145-154. Cádiz.

BERNAL, D. y LORENZO, L. (1998): "Las cerámicas importadas y la cronología del complejo alfarero", Excavaciones arqueológicas en el alfar romano de la Venta del Carmen (Los Barrios, Cádiz). Una aproximación a la producción de ánforas en la Bahía de Algeciras en época altoimperial: 63-80. Madrid.

BERNAL, D.; LORENZO, L.; EXPÓSITO, J. A.; SÁEZ, A. M. y DÍAZ, J. J. (2004): "Las innovaciones tecnológicas itálicas en la alfarería gadirita (s. II a.C.). A propósito del taller anfórico de la Avenida de Portugal", FIGLINAE BAETICAE. Talleres alfareros y producciones cerámicas en la Bética romana (ss. II a.C. - VII d.C.), BAR International Series 1266, Oxford, vol. 2: 621-632.

BERNAL, D.; MONTERO, A. I.; SÁEZ, A. M.; LAGÓSTENA, J. y LORENZO, L. (e.p.): "Novedades sobre la producción anfórica púnico-gaditana (ss. V-I a.C.). Avance del taller alfarero de la C/ Asteroides (San Fernando, Cádiz)", IV Congreso Peninsular de Arqueología (Faro, septiembre de 2004).

BERNAL, D.; SÁEZ, A.; SÁEZ, A. M.; DÍAZ, J. J.; LORENZO, L. y TOLEDO, F. (2004): La Carta Arqueológica Municipal de San Fernando, Sevilla.

BERNI, P. (1998): Las ánforas de aceite de la Bética y su presencia en la Cataluña romana, Col.lecció Instrumenta 4, Barcelona.

BEZECZKY, T. (1998): "The amphorae of Val San Pietro (Pula)", Bonifiche e drenaggi con anfore in epoca romana : aspetti tecnici e topografici: 287-289. Módena.

BLACKMAN, D. (1990): "Ancient Harbours in Spain”, Le commerce maritime romain en Méditerranée occidentale: $123-127$. Estrasburgo.

BLANCO, F. (1981): "Restos de una embarcación medieval en El Portal", Boletín del Museo de Cádiz, II: 77-86. San Fernando.

BLOT, M. L. B.H. PINHEIRO (2003): Os portos na origen dos centros urbanos. Contributo para a arqueología das cidades marítimas e fuúvio-maritimas em Portugal, Trábalos de Arqueología 28, Lisboa. 
BRUNI, S. (2000, a cura di): Le navi antiche di Pisa. Ad un anno dall'inizio delle ricerche, Florencia.

BRUNI, S. (2003, a cura di): Il porto urbano di Pisa antica. La fase etrusca. Il contesto e il relitto ellenistico, Milán.

BRUNO, B. (1998): “Le strutture di bonifica con anfore rinvenute a Milano nello scavo dell'Università Católica", Bonifiche e drenaggi con anfore in epoca romana : aspetti tecnici e topografici: 259-264. Módena.

BURNOUF, J. y LAUBENHEIMER, F. (e.p.): "Des vides sanitaires. Place Bellecour à Lyon", Les amphores en Gaule. Production et circulation 2.

BURRIEL ALBERICH, J.; RIBERA I LACOMBA, A. y SERRANO MARCO, M.L. (2003): "Un área portuaria romana al norte de Valentia", en Puertos fluviales antiguos: ciudad, desarrollo e infraestructuras (G. Pascual y J. Pérez eds.): 127-141. Valencia.

CALLENDER, M.H. (1965): Roman Amphorae (with an index of stamps), Oxford University Press, Londres.

CAPRARIIS, F. DI (2003): "Roma: i porti urbani tra continuità e trasformazioni”, en Puertos fluviales antiguos: ciudad, desarrollo e infraestructuras (G. Pascual y J. Pérez eds.): 261-275. Valencia.

CARRE, M. B.; MAROCCO, R.; SCOTTI, F. M. y PUGLIESE, N. (2003): "Quelques dones récentes sur le réseau fluvial et paléoenvironnement d'Aquileia (Italie Nord-orientale)", en Puertos fluviales antiguos: ciudad, desarrollo e infraestructuras (G. Pascual y J. Pérez eds.): 299-311. Valencia.

CARRERAS, C. y FUNARI, P.P.A. (1998): Britannia y el Mediterráneo. Estudios sobre el abastecimiento de aceite bético y africano en Britannia, Col.lecció Instrumenta 5, Barcelona.

CARRIAZO, J. DE MATA (1974-75): "Una zanja en el suelo de Sevilla", Cuadernos de la Alhambra 10-11: 91-97. Granada.

CARRIAZO, J. DE MATA (1980): Protohistoria de Sevilla, Sevilla.

CARRIÓN, J.S. (1992 a): "A palaeoecological study in the western Mediterranean area. The Upper Pleistocene pollen record from Cova Beneito (Alicante, Spain)", Palaeogeography, Palaeoclimatology, Palaeoecology, 92: 1-14.

CARRIÓN, J.S. (1992b): "Late Quaternary pollen sequence from Carihuela cave, southeastern Spain", Review of Palaeobotany and Palynology, 71: 37-77.

CASSON, L. (1965): "Harbour and river boats of Ancient Rome", Journal of Roman Studies LV: 31-39.

CASTAÑEDA FERNÁNDEZ, V. (1997): La actual San Fernando (Cádiz) durante el II milenio a. C. Una aportación al estudio de las formaciones económicas y sociales de la banda atlántica de Cádiz, Universidad de Cádiz, Cádiz.

CIPRIANO, S.; MAZZOCHIN, S. y PASTORE, P. (1998): "Padova. Tre casi in aree a diversa funzionalità", Bonifiche e drenaggi con anfore in epoca romana : aspetti tecnici e topografici: 161-174. Módena.

CHIC GARCÍA, G. (1979): “Gades y la desembocadura del Guadalquivir”, Gades 3: 16-17.

CHIC GARCÍA, G. (1990): La navegación por el Guadalquivir entre Córdoba y Sevilla en época romana, Écija.

CHIC GARCÍA, G. (2001): Datos para un estudio socioeconómico de la Bética. Marcas de alfar sobre ánforas olearias, Écija.

CHIC GARCÍA, G. (2003): "Nuevas consideraciones sobre la navegación fluvial del Guadalquivir", El Baetis-Guadalquivir, puerto de Hispania. Actas del I Ciclo de Estudios Históricos de Sanlúcar: 41-66. Sanlúcar.

CHIC GARCÍA, G. (2004): "La gaditanización de Hispania", Las industrias alfareras y conserveras fenicio-púnicas en la Bahía de Cádiz. Actas de los XVI Encuentros de Historia y Arqueología (San Fernando, 2000): 39-62. Córdoba. 
CLAVIJO Y CLAVIJO, S. (1961): La ciudad de San Fernando. Historia y espiritu, Ayto. de San Fernando, 2 vol., Cádiz.

CLEMENT, P.A. y HOFFLEIT, H.B. (1969): Plutarch's. Moralia VIII. Loeb Classical Library. Londres. COLLANTES DE TERÁN, F. (1977): Contribución al estudio de la topografía sevillana en la Antigüedad y en la Edad Media, Sevilla.

COMAS, M. (1997): Baetulo. Les marques d'àmfora, Barcelona.

CONCEPCIÓN, Fray J. de la. (1690): Emporio del orbe. Cádiz ilustrado, Ámsterdam.

DALL'AGLIO, P.L. (1998): “Appunti sul problema del drenaggio delle acque in età romana nella VIII Regio", Bonifiche e drenaggi con anfore in epoca romana: aspetti tecnici e topografici: 81-84. Módena.

DANGREAUX, B. y DESBAT, A. (1987-88): “Les amphores du dépotoir flavien du Bas-de-Loyasse à Lyon", Gallia 45: 115-153.

DA VILLA, P.C. y SANDRINI, G.M. (1998): “Concordia Sagittaria (VE)”, Bonifiche e drenaggi con anfore in epoca romana : aspetti tecnici e topografici: 113-128. Módena.

DE VANNA, L. (1998): "Padova. Le evidenze dell'area della clinica pediatrica di via Giustiniani", Bonifiche e drenaggi con anfore in epoca romana : aspetti tecnici e topografici: 181-184. Módena.

FABIÃO, C. (2004): "Centros oleiros da Lusitania. Balanço dos conhecimentos e perspectivas de investigaçao", FIGLINAE BAETICAE. Talleres alfareros y producciones cerámicas en la Bética romana (ss. II a.C. - VII d.C.), BAR International Series 1266, Oxford, vol. 1: 379-410.

FALGUERA, J.M.; BERNARD, H. y JEZEGOU, M.P. (2003): "Dones d'archeologie sous-marine recentes a Port la Nautique. Pour une approche du systeme portuaire narbonnais", en Puertos fluviales antiguos: ciudad, desarrollo e infraestructuras (G. Pascual y J. Pérez eds.): 203-212. Valencia.

FARIÑAS, L.; FERNÁNDEZ, W. y HESNARD, A. (1977): “Contribution à l'établissement d'une typologie des amphores dites Dressel 2-4", Methodes classiques et methodes formelles dans l'étude des amphores: 179-206. Ecole Française de Rome, Roma.

FELICI, E. (2001): "Costruire nell'acqua: i porti antiqui”, en Lezioni Fabio Facenna (a cura di M. Giacobelli): 161-178. Bari.

FERNÁNDEZ-PALACIOS, A.; FERNÁNDEZ-PALACIOS, J. y GIL, J. (1988): El litoral. I Guía Naturalística de la Provincia de Cádiz. Libros de la Diputación de Cádiz.

FOZZATTI, L. y TONIOLO, A. (1998): “Argini-strade nella laguna di Venezia”, Bonifiche e drenaggi con anfore in epoca romana: aspetti tecnici e topografici: 197-208. Módena.

FRANCO SILVA, A. (1995): La Isla de León en la Baja Edad Media, Excmo. Ayuntamiento de San Fernando, Fundación Municipal de Cultura, Cádiz.

FREED, J. (1998): "Stamped Tarraconensian Dressel 2-4 Amphoras at Carthage", El ví a l'Antiguitat, 2 Congreso Internacional: 350-356. Badalona.

GALLINA, M. ANTICO (1998): "Le anfore come elemento funciónale a interventi di bonifica geotecnica e hidrogeológica: alcune riflessioni", Bonifiche e drenaggi con anfore in epoca romana : aspetti tecnici e topografici: 73-79. Módena.

GARCÍA VARGAS, E. (1998): La producción de ánforas en la Bahía de Cádiz en época romana (ss. II a.C.-IV d. C.), Ed. Gráficas Sol, Écija.

GARCÍA VARGAS, E. (2001): "Las producciones de la figlina: ánforas", Arqueología y Rehabilitación en el Parlamento de Andalucía. Investigaciones arqueológicas en el antiguo Hospital de las Cinco Llagas de Sevilla: 200-219. Sevilla.

GARCÍA, E.; ALONSO, C.; JIMÉNEZ, M. y MACLINO, I. (2004): "Perspectivas de investigación sobre puertos y fondeaderos en el sur de Hispania", ANSER, Seminario 2, Le strutture dei Porti e degli approdi antichi (Roma, abril de 2004): 3-21. Roma. 
GIL, L.; DÍAZ FERNÁNDEZ, P.M.; JIMÉNEZ, M.P.; ROLDÁN, M.; ALÍA, R.; AGÚNDEZ, D.; DE MIGUEL, J.; MARTÍN, S. y DE TUERO, M. (1996): Regiones de procedencia de Pinus halepensis, Mill. Organismo Autónomo de Parques Nacionales. Ministerio de Medio Ambiente. Madrid.

GISBERT, J. (1987): "La producció de ví al territori de Dianium durant l'Alt Imperi: el taller d'àmfores de la vil.la romana de L'Almdrava (Setla-Mirarrosa-Miraflor)", El Ví a l'Antiguitat. Economia, producció y comerç al Mediterrrani Occidental: 104-118. Badalona.

GOIRAN, J-P.; BOURCIER, M. y MORHANGE, C. (2003): "Histoire du colmatage d'un bassin portuaire antique a Alexandrie", en Puertos fluviales antiguos: ciudad, desarrollo e infraestructuras (G. Pascual y J. Pérez eds.): 331-341. Valencia.

GRAU, E. (1984): El hombre y la vegetación del Neolitico a la Edad del Bronce Valenciano en La Safor (provincia de Valencia) según el análisis antracológico de la Cova de la Recambra. Tesis de Licenciatura. Universitat de Valencia.

GRAU, E. (1991): El uso de la madera en yacimientos valencianos de la Edad del Bronce a la época visigoda. Datos etnobotánicos y reconstrucción ecológica según la Antracología. Tesis doctoral. Universitat de Valencia. Servicio de Publicaciones. $N^{o}$ de Serie : 695-2

GUERRERO MISA, L. (1984): "Un ancla bizantina hallada en la Plaza Nueva de Sevilla", Museos 2: 95-98. Madrid.

HESNARD, A. (1995): "Les ports antiques de Marseille. Place Jules Verne", Journal of Roman Archaeology 8: 65-78.

HOPF, M. (1979): "Pflanzchiche reste aus Zambujal", en E. Sangmeister y H. Schubart eds., Zambujal: die Grabungen 1964 bis 1973. Madrider Beiträge 5 : 315-341.

HOPF, M. (1991): "South and Southwest Europe", en W. Van Zeist, K. Vasilikova and K. Behre eds., Progress in Old World Palaeoethnobotany, Balkema: 241-277. Rotterdam.

JACQUIOT, v. (1955): Atlas d'Anatomie des Bois de Conifères. Centre Technique du Bois, Paris 2 vols. Texte et Planches.

LAGÓSTENA BARRIOS, L. y BERNAL CASASOLA, D. (2004): “Alfares y producciones cerámicas en la provincia de Cádiz. Balance y perspectivas", FIGLINAE BAETICAE. Talleres alfareros y producciones cerámicas en la Bética romana (ss. II a.C. - VII d.C.), BAR International Series 1266, vol. 1: 39-124. Oxford.

LAUBENHEIMER, F. (1998a): "L'eau et les amphores. Les systèmes d'assainissement en Gaule romaine", Bonifiche e drenaggi con anfore in epoca romana: aspetti tecnici e topografici: 47-70. Módena.

LAUBENHEIMER, F. (1998b): "Un épave de Bétique au large du Cap Corse: La Tour de Ste. Marie", III Jornadas de Arqueología Subacuática. Puertos antiguos y comercio marítimo (Valencia 1997): 311-328. Valencia.

LEHMANN-HARTLEBEN, K. (1923): Die antiken Hafenanlagen des Mittelmeers. Beiträge zur Geschichte des Städtebaues im Altertum, Leipzig.

LONG, L. y SINTES, C. (2003): "Comerse maritime et fluvial aux embouchures du Rhône: le rôle d'Arles dans l'Antiquité", en Puertos fluviales antiguos: ciudad, desarrollo e infraestructuras (G. Pascual y J. Pérez eds.): 183-201. Valencia.

LÓPEZ DE LA ORDEN. M. D. y PÉREZ LÓPEZ, I. (1980): "Depósito de ánforas en las cercanías de Rota", Boletín del Museo de Cádiz, I: 51-54. Cádiz.

LUNARDI, P. (1998): "Significato e obiettivi del consolidamento dei suoli oggi e nell'antichità", Bonifiche e drenaggi con anfore in epoca romana : aspetti tecnici e topografici: 37-46. Módena.

MADOZ, P. (1987): Diccionario geográfico-estadístico-histórico de España y sus posesiones de Ultramar. (1845-1850). Nueva edición correspondiente a la Provincia de Cádiz, Cádiz, Edición corregida por R. Corzo y M. Toscano.

ISSN: 1133-4525 ISSN-e: 2255-3924

SPAL 14 (2005)

http://dx.doi.org/10.12795/spal.2005.i14.07 
MANACORDA, D. (1977): “Anfore spagnole a Pompei”, L'instrumentum domesticum di Ercolano e Pompei nella prima età imperiale, Roma.

MANASSE, G. C. (1998): "Banchi d'anfore romane a Verona: nota topografica ", Bonifiche e drenaggi con anfore in epoca romana : aspetti tecnici e topografici: 185-196. Módena.

MANTAS, V. GIL (2003): "O porto romano de Lisboa", en Puertos fluviales antiguos: ciudad, desarrollo e infraestructuras (G. Pascual y J. Pérez eds.): 13-29. Valencia.

MARIOTTI, V. (1998): "Cremona. Il drenaggio con anfore di via Amidani/Bissolati”, Bonifiche e drenaggi con anfore in epoca romana : aspetti tecnici e topografici: 291-292. Módena.

MARSDEN, P. (1994): Ships of the port of London. First to eleventh centuries A.D., Londres.

MARTIN KILCHER, S. (1998): "Le vin dans la Colonia Iulia Karthago", El ví a l'Antiguitat, 2 Congreso Internacional: 511-529. Badalona.

MAYET, F. y TAVARES DA SILVA, C. (1998): L'atelier d'amphores de Pinheiro (Portugal), París.

MAYET, F. y TAVARES DA SILVA, C. (2002): L'atelier d'amphores d'Abul (Portugal), París.

METCALFE, C.R. (1958): "Gorham's cave : Report on the plant remains". Bull. Ins. of Archaeology, 4, p. 219.

MILNE, G. (1982): "Recent work on London's Roman Harbour", International Journal of Nautical Archaeology 11, 2: 162-164.

MILNE, G. (1985): The port of Roman London, Londres.

MIRÓ. J. (1988): La producción de ánforas romanas en Catalunya. Un estudio sobre el comercio del vino de la Tarraconense (siglos I a.C. - I d.C.), B.A.R., international series 473, Oxford.

MODRZEWSKA, I. (1996): Anfore spagnole nel Veneto. Testimonianze dei contatti commerciali Baetica - Venetia, Pisa.

MONETI, A. y STOCCO, R. (1998): "Padova. L'area periurbana: viale della Rotonda e via Trieste", Bonifiche e drenaggi con anfore in epoca romana : aspetti tecnici e topografici: 175-180. Módena.

MORHANGE, C.; ESPIC, K.; BRUZZI, C.; BOURCIER, M.; OBERLIN, C. y SERHAL, C. (2003): "Nouvelles donnees sedimentologiques sur les milieux portuaires antiques de Sidon (Campagne Cedre 2000)", en Puertos fluviales antiguos: ciudad, desarrollo e infraestructuras (G. Pascual y J. Pérez eds.): 323-329. Valencia.

OJEDA TORRES, J. M. (1995): "Filóstrato V A, 5, 6 y la procuratela ad ripam Baetis", Kolaios 4: 381-386.

ORDÓÑEZ, S. (1998): Primeros pasos de la Sevilla romana (s. I a.C. - I d.C.), Sevilla.

ORDÓÑEZ, S. (2003): "El puerto romano de Hispalis", en Puertos fluviales antiguos: ciudad, desarrollo e infraestructuras (G. Pascual y J. Pérez eds.): 59-79. Valencia.

PANELLA, C. y FANO, M. (1977): "Le anfore con anse bifide conservate a Pompei: contributo ad una loro classificazione", Methodes classiques et methodes formelles dans l'étude des amphores: 133177. Ecole Française de Rome, Roma.

PARODI, M. (2001): Ríos y lagunas de Hispania como vías de comunicación, Écija.

PASQUALINI, M. (2000): "Les ports antiques d'Olbia (Hyères) et Toulon, environnement historique et géographique", Ports antiques et paléoenvironnements littoraux, Méditerranée 94.1.2: 69-70. Marsella.

PASQUINUCCI, M.; MENCHELLI, S. y DEL RIO, A. (1998): “Aspetti técnico-costruttivi degli horrea di Vala Volaterrana e i vespai di età tardoantica", Bonifiche e drenaggi con anfore in epoca romana : aspetti tecnici e topografici, 295-300.

PEMÁN, C. (1959): “Alfares y embarcaderos romanos en la provincia de Cádiz”, Archivo Español de Arqueología 99: 169-173. 
PÉREZ, I.; ALONSO, M.C. y NÚÑEZ, M. (1999): “Contribución al catálogo de sellos y grafitos anfóricos de la Bética. Las producciones de Puerto Real”, XXIV Congreso Nacional de Arqueología, vol. 4: 695-706. Cartagena.

PESSAVENTO MATTIOLI, S. (1998, ed.): Bonifiche e drenaggi con anfore in epoca romana: aspetti tecnici e topografici, Materiali d'archeologia 3, Módena.

PESSAVENTO, S. y RUTA, A. (1998): "Un aggiornamento sui dati di Padova”, Bonifiche e drenaggi con anfore in epoca romana : aspetti tecnici e topografici: 157-160. Módena.

PINEDA REINA, P. (2001) : Informe parcial sobre la Intervención Arqueológica de Urgencia en la E.D.A.R. de Cádiz y San Fernando. Colectores generales para la agrupación de vertidos y emisario submarino (Cádiz). Sector sin asfaltar entre Avda. de la Constitución hasta intersección con Avda. del Buen Pastor (San Fernando). Original inédito depositado en la Delegación de Cultura de Cádiz y en el Museo Histórico Municipal de San Fernando.

PINTO DA SILVA, A. R. (1971): "Aspectos da Alimentaçao de origen vegetal na pre- e protohistoria", Coleçao Natura Nova Series, 1: 33-43.

PITCHER, L.P. (1998): "Cremona e i banchi d'anfora: riflessioni sulla topografía storica”, Bonifiche e drenaggi con anfore in epoca romana : aspetti tecnici e topografici: 129-134. Módena.

POMEY, P. (1997): La navigation dans l'Antiquité, Aix-en-Provence.

QUILICI GIGLI, S. (1998): "Sulle bonifiche nell'Italia romana", Bonifiche e drenaggi con anfore in epoca romana : aspetti tecnici e topografici: 15-21. Módena.

RAMOS MUÑOZ, J. (1993): El hábitat prehistórico de El Estanquillo. San Fernando, Fundación Municipal de Cultura, Colección de Temas Isleños, Ayto. de San Fernando.

REVILLA CALVO, V. (1993): Producción cerámica y economía rural en el Bajo Ebro en época romana. El alfar de l'Aumedina (Tivissa, Tarragona). Col.lecció Instrumenta 1.

RIVAL, P. (1991): La Charpenterie Navale Romaine. Ed. du C.N.R.S. Paris.

RIVERA, D. y OBÓN DE CASTRO, C. (1991): La Guía INCAFO de las Plantas útiles y venenosas de la Península Ibérica y Baleares. INCAFO, S.A. Madrid.

RODRÍGUEZ, M.O. (1992): "Human-plant relationships during the Copper and Bronze Ages in the Baza and Guadix basins (Granada, Spain)", Bull. Soc. Bot. Fr., 139. Actual. Bot. 2/3/4: 451-464.

RODRÍGUEZ, M.O.; AGUAYO, P. y MORENO, F. (1992): "The environment in the Ronda basin (Málaga, Spain) during recent prehistory based on an anthracological study of Old Ronda", Bull. Soc. Bot. Fr., 139. Actual. Bot. 2/3/4: 715-725.

ROS, M.T. (1992): "Les apports de l'Anthracologie à l'étude du paléoenvironnement végétal en Catalogne (Espagne)", Bull. Soc. Bot. Fr., 139. Actual. Bot. 2/3/4: 483-493.

ROSADA, G. (2003): "Il porto di Aquileia nel sistema degli scali fluvio-lagunari della Decima Regio", en Puertos fluviales antiguos: ciudad, desarrollo e infraestructuras (G. Pascual y J. Pérez eds.): 277-297. Valencia.

ROSELLÓ, E. y MORALES, A. eds. (1994): Castillo de Doña Blanca. Archeo-environmental investigations in the Bay of Cádiz, Spain (750-500 BC), BAR International Series, 593, Oxford.

ROUGÉ, J. (1966): Recherches sur l'organisation du commerce en Méditerranée sous l'Empire Romain, París.

SÁEZ, A. M.; MONTERO, R.; TOBOSO, E. J. y DÍAZ, J. J. (2003): "Control arqueológico en el yacimiento púnico-romano de Gallineras (San Fernando, Cádiz)", Anuario Arqueológico de Andalucia/2000, III: 166-173. Sevilla.

SCHULZ, H. D. y MAASS LINDEMANN, G. (1997): Prospecciones geo-arqueológicas en las costas de Ibiza, TMAI, 38, Ibiza.

SCOTTI, F. M. (1998): "Bonifiche e drenaggi con anfore ad Aquileia", Bonifiche e drenaggi con anfore in epoca romana : aspetti tecnici e topografici: 107-111. Módena.

ISSN: 1133-4525 ISSN-e: 2255-3924

SPAL 14 (2005)

http://dx.doi.org/10.12795/spal.2005.i14.07 
SINTES, C. (1999-2000): "Le pont de bateaux d'Arles", en La Loire et les fleuves de la Gaule Romaine et de regions voisines, Caesarodunum XXXIII-XXXIV (ed. Par R. Bedon y A. Malissard): 153-175.

SPAAR, S.L. (1981): The ports of Roman Baetica. A study of provincial harbours and their function from a historical and archaeological perspective, Ann Arbor.

TIRELLI, M. (1987): "Oderzo: rinvenimenti di un molo fluviale in via delle Grazie", Quaderni di Archeologia Veneta III: 81-85.

TIRELLI, M.; FERRARINI, F. y CIPRIANO, S. (1998): "Oderzo (TV): strutture di bonifica con anfore presso il molo fluviale e la necropoli sud-orientale", Bonifiche e drenaggi con anfore in epoca romana : aspetti tecnici e topografici: 135-156. Módena.

TIRELLI, M. y TONIOLO, A. (1998): “Altino. Strutture ad anfore in aree a diversa funzionalità", Bonifiche e drenaggi con anfore in epoca romana : aspetti tecnici e topografici: 87-106. Módena.

UGGERI, G. (1968): "La terminología portuale romana", Studi Italiani di Filología Clásica XL: 225-254.

URTEAGA, M. (2001): "El puente romano del Bidasoa", Boletín Arkeolan 10: 18-21, Donostia-San Sebastián.

URTEAGA, M. (2003): "El puerto romano de Oiasso (Irún) y la desembocadura del río Bidasoa", AA.VV. Gijón. Puerto romano. Navegación y comercio en el Cantábrico durante la Antigüedad (C. Fernández Ochoa ed.): 193-212. Madrid.

UZQUIANO, P. (1995): "El Valle del Duero en la Edad del Hierro. El aporte de la Antracología", en G. Delibes; F. Romero y A. Morales eds.: Arqueología y Medioambiente. El primer milenio A.C. en el Duero medio, Junta de Castilla y León: 395-416. Valladolid.

UZQUIANO, P. (2002): "Vegetation and firewood management at Cueva de La Vaquera (Segovia, Spain) between 6-3.7 Kyr. BP: Anthracological contribution to the Landscape archaeology of the Spanish Central Mountains". B.A.R. International Series 1063, Oxford University Press: 109-112.

UZQUIANO, P. (en prensa): Antracoanálisis de Cancho Roano (Zalamea de la Serena, Badajoz). Maderas y combustible empleados en un santuario de época orientalizante (ss. VII-IV a C.).

VERNET, J.L.; OGEREAU, P. ; FIGUEIRAL, I. ; MACHADO, M. y UZQUIANO, P. (2001): Flore des charbons de bois préhistoriques et récents de l'Europe du sud-ouest (France, Péninsule Ibérique, et Iles Canaries). Guide d'identification. Ed. Du C.N.R.S. Paris.

YLL, E. I. (1988): “Análisis de polen y palinograma”, en C. Olaria (ed.) Cova Fosca. Un asentamiento mesoneolítico de cazadores y pastores en la Serranía del Alto Maestrazgo. Monografies de Prehistoria i Arqueología Castellonenques. Diputación de Castellón. 